Cover. East River industrial area, Brunswick, Glynn County, Georgia. Photo by Alan M. Cressler, U.S. Geological Survey. 


\section{Groundwater Conditions and Studies in the Brunswick-Glynn County Area, Georgia, 2008}

By Gregory S. Cherry, Michael F. Peck, Jaime A. Painter, and Welby L. Stayton

Prepared in cooperation with the City of Brunswick and Glynn County

Open-File Report 2009-1275 


\section{U.S. Department of the Interior \\ KEN SALAZAR, Secretary \\ U.S. Geological Survey \\ Marcia K. McNutt, Director}

U.S. Geological Survey, Reston, Virginia: 2010

For more information on the USGS - the Federal source for science about the Earth, its natural and living resources, natural hazards, and the environment, visit $h t t p: / / W w w . u s g s . g o v$ or call 1-888-ASK-USGS.

For an overview of USGS information products, including maps, imagery, and publications, visit http://www.usgs.gov/pubprod.

To order this and other USGS information products, visit http://store.usgs.gov.

Any use of trade, product, or firm names is for descriptive purposes only and does not imply endorsement by the U.S. Government.

Although this report is in the public domain, permission must be secured from the individual copyright owners to reproduce any copyrighted materials contained within this report.

Suggested citation:

Cherry, G.S., Peck, M.F., Painter, J.A, and Stayton, W.L., 2010, Groundwater conditions and studies in the Brunswick-Glynn County area, Georgia, 2008: U.S. Geological Survey Open-File Report 2009-1275, 54 p. 


\section{Contents}

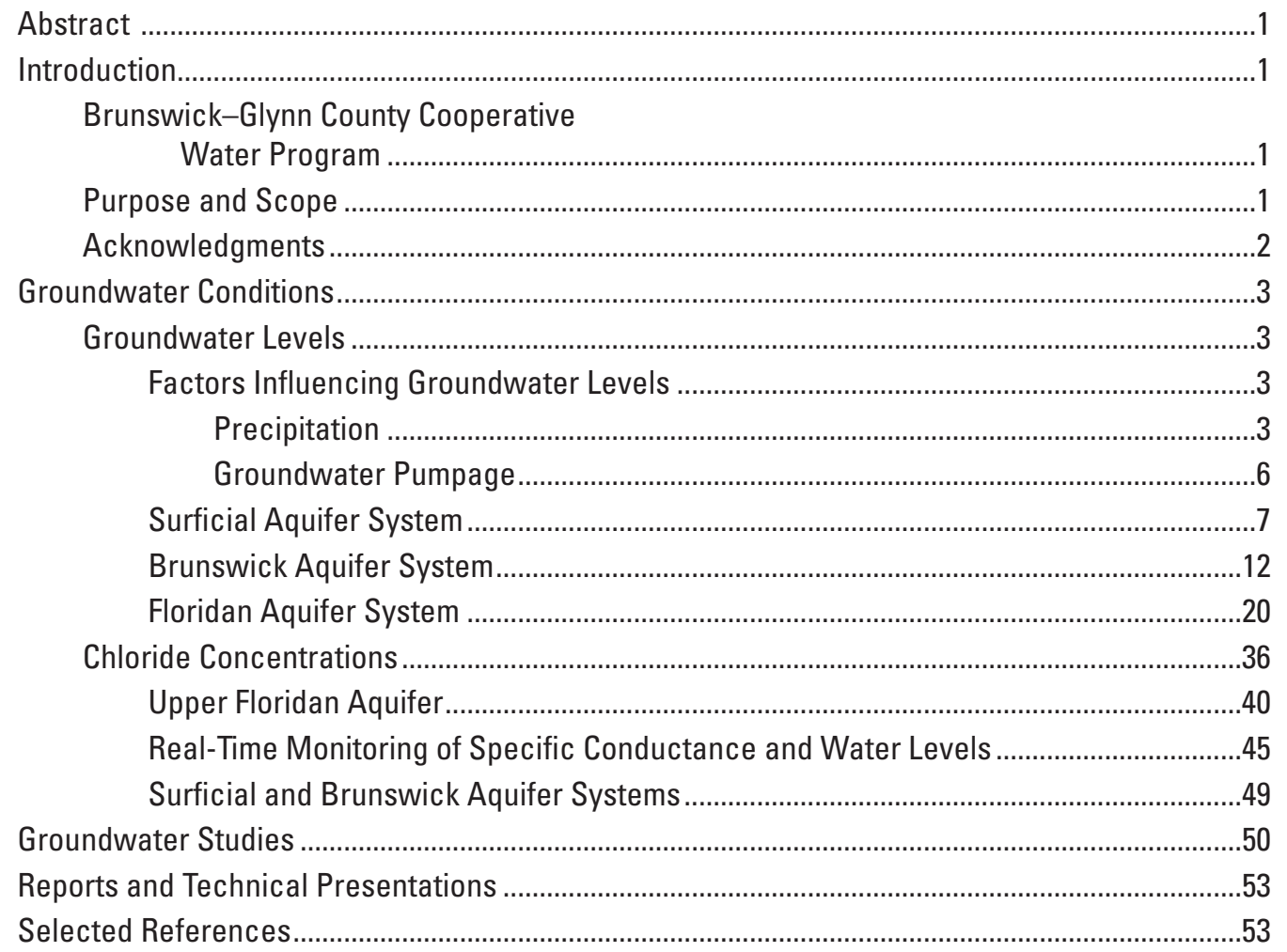




\section{Figures}

1. Map showing location of study area and continuous groundwater-level monitoring network for the Brunswick-Glynn County area, Georgia

2-3. Graphs showing-

2. Cumulative departure from normal precipitation and total daily precipitation at real-time climatic monitoring site,

College of Coastal Georgia, Georgia, January 2000-December 2008

3. Major groundwater pumpage from the Upper Floridan aquifer in the Brunswick-Glynn County area, Georgia, 1940-2008..

4. Map showing groundwater levels in the surficial aquifer system in the central and southern coastal areas, Georgia, 2008.

5-8. Graphs showing periodic and daily mean water levels, surficial aquifer system, Glynn County, Georgia-

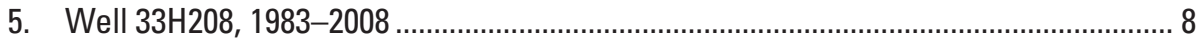

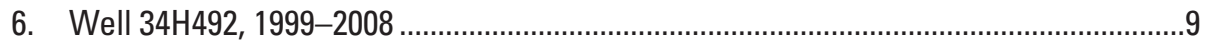

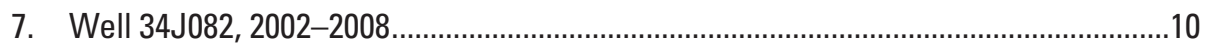

8. Well 34H515, 2005-2008 ........................................................................................11

9. Map showing groundwater levels in the Brunswick aquifer system in the central and southern coastal areas, Georgia, 2008

10-16. Graphs showing periodic and daily mean water levels, upper Brunswick aquifer, Glynn County, Georgia-

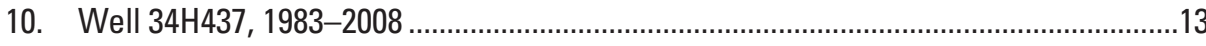

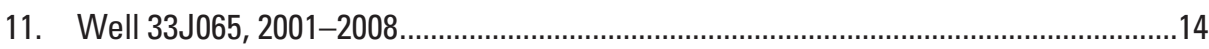

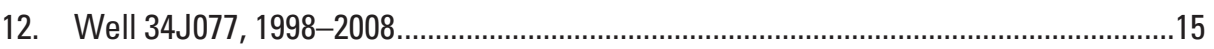

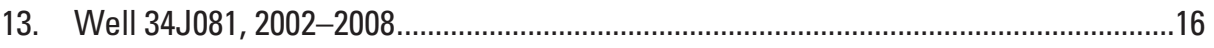

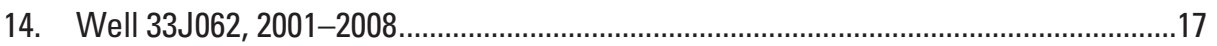

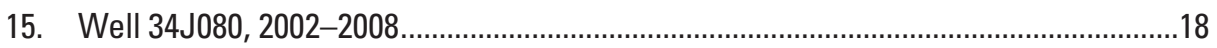

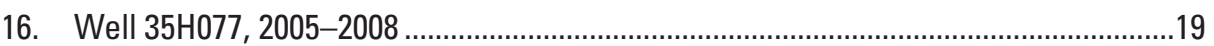

17. Map showing groundwater level monitoring network and potentiometric surfaces for the Upper Floridan aquifer in the Brunswick-Glynn County area, July 2008

18-23. Graphs showing periodic and daily mean water levels, Upper Floridan aquifer, Glynn County, Georgia-

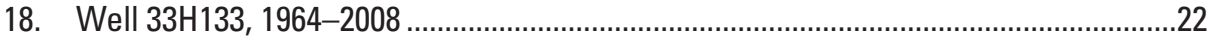

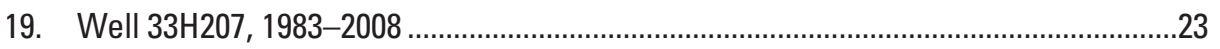

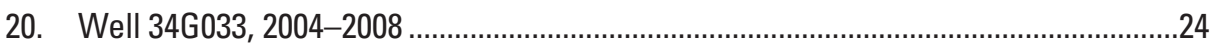

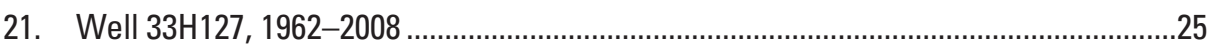

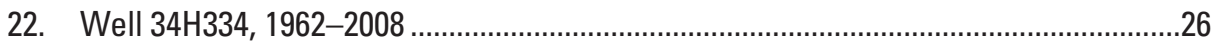

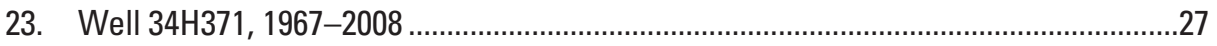

24. Map showing groundwater levels in the Lower Floridan aquifer in the central and southern coastal areas, Georgia, 2008...... 
25-31. Graphs showing periodic and daily mean water levels,

Lower Floridan aquifer, Glynn County, Georgia-

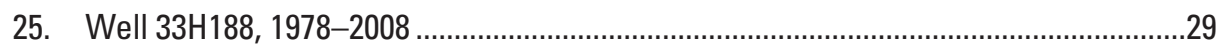

26. Well 33H206, 1983-2008

27. Well 33J044, 1979-2008..............................................................................

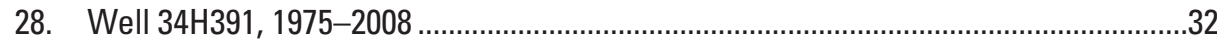

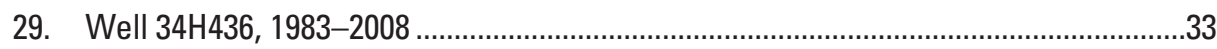

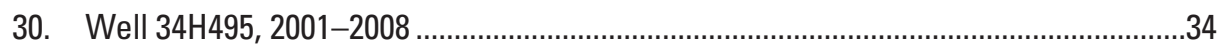

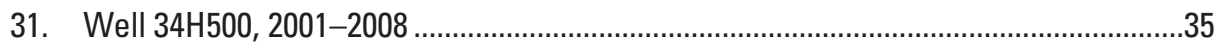

32-34. Maps showing-

32. Chloride-monitoring network for the Brunswick-Glynn County area, Georgia, location and enlarged area.

33. Chloride concentration in the Upper Floridan aquifer in the Brunswick-Glynn County area, Georgia, July 2008

34. Change in chloride concentration in the Upper Floridan aquifer in the Brunswick-Glynn County area, Georgia, from 2007 to 2008

35-41. Graphs showing-

35. Chloride concentration in water for selected wells in the southern Brunswick-Glynn County area, Georgia, 1968-2008

36. Chloride concentration in water for selected wells in the northern Brunswick-Glynn County area, Georgia, 1968-2008

37. Daily mean groundwater levels and periodic specific conductance in the Upper Floridan aquifer at well 34H514, Perry Park, Brunswick-Glynn County area, Georgia, 2008.

38. Correlation between chloride concentration and specific conductance from groundwater samples taken in the Brunswick-Glynn County area, Georgia, July 2008.

39. Daily mean water levels in wells $33 \mathrm{H} 324$ and $33 \mathrm{H} 325$, and specific conductance in well $33 \mathrm{H} 325$ Upper Floridan aquifer, Brunswick-Glynn County area, Georgia, 2008

40. Daily mean groundwater levels and periodic specific conductance in the Upper Floridan aquifer at wells 34H504 and 34H505, Brunswick-Glynn County area, Georgia, 2008.

41. Chloride concentration in well $34 \mathrm{H} 438$ and replacement well $34 \mathrm{H} 515$, surficial aquifer system, in the Brunswick-Glynn County area, Georgia, 1983-2008

42. Maps showing location of 24-county coastal Georgia area and model extent, and model grid and distribution of pumpage by model layer for layers 7 and 9 , Upper Floridan aquifer, Brunswick-Glynn County area, Georgia, 2004.

43. Generalized correlation of geologic and hydrogeologic units and model layers 


\section{Tables}

1. Brunswick-Glynn County, Georgia, groundwater-level monitoring network, 2008...........4

2. Chloride concentrations and specific conductance in water samples collected from wells in the Brunswick-Glynn County area, Georgia, July and August 2007 (chloride only) and July 2008

\section{Conversion Factors and Datums}

\begin{tabular}{|c|c|c|}
\hline Multiply & By & To obtain \\
\hline \multicolumn{3}{|c|}{ Length } \\
\hline inch & 2.54 & centimeter $(\mathrm{cm})$ \\
\hline foot $(\mathrm{ft})$ & 0.3048 & meter $(\mathrm{m})$ \\
\hline mile (mi) & 1.609 & kilometer $(\mathrm{km})$ \\
\hline \multicolumn{3}{|c|}{ Area } \\
\hline square foot $\left(\mathrm{ft}^{2}\right)$ & 0.09290 & square meter $\left(\mathrm{m}^{2}\right)$ \\
\hline square mile $\left(\mathrm{mi}^{2}\right)$ & 2.590 & square kilometer $\left(\mathrm{km}^{2}\right)$ \\
\hline \multicolumn{3}{|c|}{ Volume } \\
\hline gallon (gal) & 3.785 & liter $(\mathrm{L})$ \\
\hline Million gallons (Mgal) & 3,785 & cubic meter $\left(\mathrm{m}^{3}\right)$ \\
\hline
\end{tabular}

Temperature in degrees Celsius $\left({ }^{\circ} \mathrm{C}\right)$ may be converted to degrees Fahrenheit $\left({ }^{\circ} \mathrm{F}\right)$ as follows:

$$
{ }^{\circ} \mathrm{F}=\left(1.8 \times{ }^{\circ} \mathrm{C}\right)+32
$$

Temperature in degrees Fahrenheit $\left({ }^{\circ} \mathrm{F}\right)$ may be converted to degrees Celsius $\left({ }^{\circ} \mathrm{C}\right)$ as follows:

$$
{ }^{\circ} \mathrm{C}=\left({ }^{\circ} \mathrm{F}-32\right) / 1.8
$$

Vertical coordinate information is referenced to the North American Vertical Datum of 1988 (NAVD 88).

Historical data collected and stored as National Geodetic Vertical Datum of 1929 (NGVD 29).

Horizontal coordinate information is referenced to the North American Datum of 1983 (NAD 83).

Altitude, as used in this report, refers to distance above the vertical datum.

Specific conductance is given in microsiemens per centimeter at 25 degrees Celsius $\left(\mu \mathrm{S} / \mathrm{cm}\right.$ at $\left.25^{\circ} \mathrm{C}\right)$.

Concentrations of chemical constituents in water are given either in milligrams per liter (mg/L) or micrograms per liter $(\mu \mathrm{g} / \mathrm{L})$. 


\title{
Groundwater Conditions and Studies in the Brunswick-Glynn County Area, Georgia, 2008
}

\author{
By Gregory S. Cherry, Michael F. Peck, Jaime A. Painter, and Welby L. Stayton
}

\begin{abstract}
The Upper Floridan aquifer is contaminated with saltwater in a 2-square-mile area of downtown Brunswick, Georgia. This contamination has limited development of the groundwater supply in the Glynn County area. Hydrologic, geologic, and water-quality data are needed to effectively manage water resources. Since 1959, the U.S. Geological Survey has conducted a cooperative water program with the City of Brunswick to monitor and assess the effect of groundwater development on saltwater contamination of the Floridan aquifer system.

During calendar year 2008, the cooperative water program included continuous water-level recording of 12 wells completed in the Floridan, Brunswick, and surficial aquifer systems; collecting water levels from 21 wells to map the potentiometric surface of the Upper Floridan aquifer during July 2008; and collecting and analyzing water samples from 26 wells to map chloride concentrations in the Upper Floridan aquifer during July 2008. Equipment was installed on 3 wells for real-time water level and specific conductance monitoring. In addition, work was continued to refine an existing groundwater-flow model for evaluation of watermanagement scenarios.
\end{abstract}

\section{Introduction}

In the Brunswick, Georgia, area (fig. 1), saltwater has been contaminating the Upper Floridan aquifer for about 50 years. As of 2008, within a 2-square-mile $\left(\mathrm{mi}^{2}\right)$ area in downtown Brunswick, the aquifer yielded water with a chloride concentration greater than 2,000 milligrams per liter $(\mathrm{mg} / \mathrm{L})$, which exceeds the State and Federal secondary drinking-water standard of $250 \mathrm{mg} / \mathrm{L}$ (Georgia Environmental Protection Division, 1997; U.S. Environmental Protection Agency, 2000). Saltwater contamination has limited further development of the Upper Floridan aquifer in the Brunswick area, prompting interest in the development of alternative sources of water supply, primarily from the shallower surficial and Brunswick aquifer systems. Monitoring groundwater conditions and conducting studies to better define the occurrence of saltwater contamination and assess alternative water sources is important for management of the water resources in the Brunswick-Glynn County area.

\section{Brunswick-Glynn County Cooperative Water Program}

The Cooperative Water Program (CWP) between the U.S. Geological Survey (USGS) and the City of Brunswick and Glynn County has been in existence since 1959.

Current cooperating entities are the Joint Water and Sewer Commission (JWSC) and the Jekyll Island Authority. The CWP was initiated in response to concerns about chloride contamination of the Upper Floridan aquifer, which first became evident during the late 1950s. Since its inception, the CWP has placed emphasis on providing the necessary information about the Floridan aquifer system to manage saltwater intrusion and evaluate water-resources data.

\section{Purpose and Scope}

Hydrologic, geologic, and water-quality data are needed to effectively manage water resources in the coastal area of Georgia. During calendar year 2008, the CWP, which includes all of Glynn County (fig. 1), continued and included continuous water-level monitoring of 12 wells completed in the Floridan, Brunswick, and surficial aquifer systems. Water levels also were collected from 21 wells to map the potentiometric surface of the Upper Floridan aquifer during July 2008. In addition, water samples were collected and analyzed from 26 wells in order to assess the configuration of the chloride plume in the Upper Floridan aquifer near the City of Brunswick during July 2008. Work was continued to refine an existing groundwater-flow model (Payne and others, 2005) in order to evaluate selected water-management scenarios. 


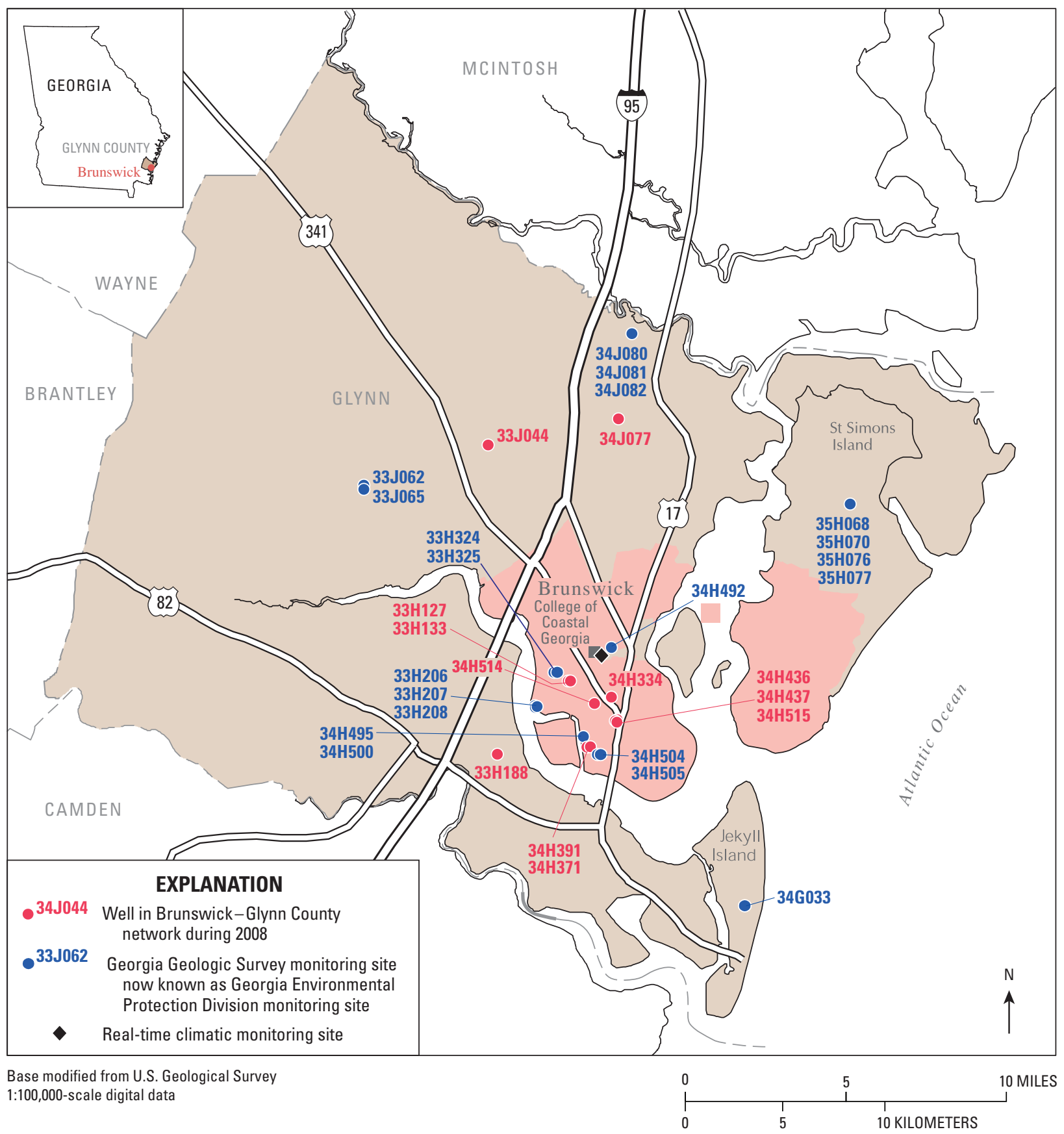

Figure 1. Location of study area and continuous groundwater-level monitoring network for the Brunswick-Glynn County area, Georgia.

\section{Acknowledgments}

The authors appreciate the technical feedback and guidance provided by the Brunswick-Glynn County Water Resources Management Advisory Committee (WRMAC). Several USGS employees played an important role in the collection, processing, and quality assurance of groundwater data, including Alan M. Cressler, Michael Hamrick, Jamal A. Grimes, and Christopher B. Walls. Appreciation is extended to Dorothy F. Payne for consultation and advice during development of a groundwater-flow model for the Brunswick-Glynn County area and assistance with water-quality sampling. Cartography and layout were by Caryl J. Wipperfurth and Bonnie J. Turcott. 


\section{Groundwater Conditions}

Groundwater levels and chloride concentrations in the Brunswick-Glynn County area have been monitored for several decades as part of the CWP. Precipitation and groundwater pumpage are monitored to assess their influence on groundwater conditions. These data can be used to guide water-management decisions by State and local authorities.

\section{Groundwater Levels}

During calendar year 2008, groundwater levels in the Brunswick-Glynn County area were continuously monitored by the USGS in 32 wells - 12 wells were funded through the CWP and 20 wells were funded through a similar program with the Georgia Department of Natural Resources, Environmental Protection Division (GaEPD) (fig. 1; table 1). Of the 32 continuous water-level recorders, 12 are completed in the Upper Floridan aquifer, 8 in the Lower Floridan aquifer, 7 in the Brunswick aquifer system, and 5 in the surficial aquifer system (table 1).

Real-time water-level monitoring systems were installed in wells completed in the upper and (or) lower water-bearing zones of the Upper Floridan aquifer that surround the area of chloride contamination-Southside Baptist Church (34H504 and 34H505), Perry Park (34H514), and Georgia-Pacific Cellulose ( $33 \mathrm{H} 324$ and $33 \mathrm{H} 325)$. These sites were then adapted for real-time specific conductance monitoring in the upper and lower water-bearing zones of the Upper Floridan aquifer.

\section{Factors Influencing Groundwater Levels}

Fluctuations and long-term trends in groundwater levels occur as a result of changes in recharge to and discharge from an aquifer. Recharge rates vary in response to precipitation, evapotranspiration, and surface-water infiltration into an aquifer. Discharge occurs as natural flow from an aquifer to streams or springs, as evapotranspiration from shallow watertable aquifers, as leakage to vertically adjacent aquifers, and as withdrawal (pumpage) from wells. When recharge to an aquifer exceeds discharge, groundwater levels rise; when discharge from an aquifer exceeds recharge, groundwater levels decline. Water levels generally are highest in the winter to early spring when precipitation is greatest, evapotranspiration is lowest, and irrigation withdrawals are minimal; water levels are the lowest during summer and fall when evapotranspiration and pumpage are greatest (Payne and others, 2005).

Hydrographs from the monitoring network are presented here to compare 2008 trends and seasonal fluctuations to period-of-record statistics in major aquifers of coastal Georgia. Additional well information can be obtained from the USGS National Water Information System (NWIS) at http://waterdata.usgs.gov/ga/nwis/gw/.
Maps of the monitoring network are presented showing the areal distribution of observation wells for each of the major aquifers of coastal Georgia and a comparison of 2008 median water levels to period of record normal water levels. This analysis is similar to that performed for a USGS report on groundwater conditions in Georgia in which the period-ofrecord comparisons must be greater than 3 years (Peck and others, 2009). For this analysis, the normal range is defined as water-level observations during the calendar year that were between the $25^{\text {th }}$ and $75^{\text {th }}$ percentiles for the period of record. The $75^{\text {th }}$ percentile means that three-quarters of the observations lie below it; the $25^{\text {th }}$ percentile means that one-quarter of the observations lie below it; and the median or $50^{\text {th }}$ percentile means that one-half of the observations lie below and one-half lie above. These comparisons were used to determine if water levels were above normal, below normal, or normal, and water levels then are shown graphically on the maps. An arrow pointing upward for 2008 represents monthly mean water levels above period-of-record normal values, an arrow pointing downward for 2008 represents monthly mean water levels below period-of-record normal values, and a circle for 2008 represents monthly mean water levels within the period-of-record normal values.

\section{Precipitation}

Precipitation in the Brunswick-Glynn County area influences groundwater levels in the shallow surficial aquifer system and, to a lesser degree, in the Brunswick aquifer system. In addition, changes in precipitation affect quantities of groundwater that can be withdrawn from deeper aquifers and, therefore, have an indirect effect on groundwater levels in the Upper Floridan aquifer. Rainfall is not evenly distributed throughout the year, and maximum rainfall generally occurs during the summer months of June, July, and August (Payne and others, 2005) when tropical systems associated with the hurricane season may produce heavy rainfall along the coast. A real-time climatic monitoring site was established as part of the CSSI on the College of Coastal Georgia campus at Brunswick to monitor precipitation in the Brunswick-Glynn County area (fig. 1). Real-time monitoring data for this site are accessible on the Web at www.georgiaweather.net (accessed on May 29, 2009).

Precipitation data and cumulative departure from normal during 2000-2008 are shown in figure 2 . The cumulative departure from normal precipitation for the period of record can be used to evaluate trends in precipitation, which typically relate to recharge of shallow aquifers. Cumulative departure depicts the long-term surplus or deficit of precipitation during a designated period and is derived by adding successive values of departure from normal precipitation. In this report, normal precipitation for a given day is defined as the average of total daily precipitation during the period of record (2000-2008). A downward trend in the cumulative departure line indicates a period of below-normal precipitation, whereas an upward trend indicates above-normal precipitation. 
Table 1. Brunswick-Glynn County, Georgia, groundwater-level monitoring network, 2008.

\begin{tabular}{|c|c|c|c|}
\hline Site name & Aquifer & Subunit & Year began \\
\hline $34 \mathrm{H} 515^{*}$ & Surficial & Deeper (confined) zone & 2005 \\
\hline $34 \mathrm{H} 437$ & Upper Brunswick & None & 1983 \\
\hline 34J077 & Upper Brunswick & None & 1998 \\
\hline $33 \mathrm{H} 127$ & Upper Floridan & Lower water-bearing zone & 1962 \\
\hline $33 \mathrm{H} 133$ & Upper Floridan & Upper water-bearing zone & 1964 \\
\hline 34H334 & Upper Floridan & Lower water-bearing zone & 1962 \\
\hline $34 \mathrm{H} 371$ & Upper Floridan & Upper water-bearing zone & 1967 \\
\hline $34 \mathrm{H} 514 * *$ & Upper Floridan & Upper water-bearing zone & 2007 \\
\hline $33 \mathrm{H} 188$ & Lower Floridan & Fernandina permeable zone & 1978 \\
\hline 33J044 & Lower Floridan & Undifferentiated & 1979 \\
\hline 34H391 & Lower Floridan & Brackish water zone & 1970 \\
\hline $34 \mathrm{H} 436$ & Lower Floridan & Brackish water zone & 1983 \\
\hline \multicolumn{4}{|c|}{ Additional wells (funded by Georgia Environmental Protection Division) } \\
\hline $33 \mathrm{H} 208$ & Surficial & Deeper (confined) zone & 1983 \\
\hline $34 \mathrm{H} 492$ & Surficial & Water-table zone & 1999 \\
\hline 34J082 & Surficial & None & 2002 \\
\hline $35 \mathrm{H} 076$ & Surficial & Deeper (confined) zone & 2007 \\
\hline 33J065 & Upper Brunswick & None & 2001 \\
\hline 34J081 & Upper Brunswick & None & 2002 \\
\hline 33J062 & Lower Brunswick & None & 2001 \\
\hline 34J080 & Lower Brunswick & None & 2002 \\
\hline $35 \mathrm{H} 077$ & Lower Brunswick & None & 2005 \\
\hline $33 \mathrm{H} 207$ & Upper Floridan & Upper water-bearing zone & 1983 \\
\hline $33 \mathrm{H} 324 * *$ & Upper Floridan & Upper water-bearing zone & 2007 \\
\hline $33 \mathrm{H} 325^{* *}$ & Upper Floridan & Lower water-bearing zone & 2007 \\
\hline $34 \mathrm{G} 033$ & Upper Floridan & None & 2004 \\
\hline $34 \mathrm{H} 504 * *$ & Upper Floridan & Upper water-bearing zone & 2007 \\
\hline $34 \mathrm{H} 505^{* *}$ & Upper Floridan & Lower water-bearing zone & 2007 \\
\hline $35 \mathrm{H} 070$ & Upper Floridan & Upper water-bearing zone & 2007 \\
\hline $33 \mathrm{H} 206$ & Lower Floridan & Brackish water zone & 1983 \\
\hline $34 \mathrm{H} 495$ & Lower Floridan & Fernandina permeable zone & 2001 \\
\hline $34 \mathrm{H} 500$ & Lower Floridan & Fresh water-bearing zone & 2001 \\
\hline $35 \mathrm{H} 068$ & Lower Floridan & Fresh water-bearing zone & 2007 \\
\hline
\end{tabular}


Cumulative departure data from the Coastal Georgia Community College in Brunswick, indicate a period of below-normal precipitation from January 2000 to May 2002, corresponding to a drought period that began during the middle of 1998 (Barber and Stamey, 2000). Between June 2004 and October 2005, precipitation was mostly above normal with one short period of below-normal precipitation between October 2004 and February 2005.
Rainfall was mostly below normal from October 2005 through December 2008 (fig. 2A). The maximum amount of rainfall recorded in a 24-hour period was 6.05 inches on October 5, 2005 (fig. 2B). During a 6-day period (October 2-7, 2005), rainfall, associated with Tropical Storm Tammy, totaled nearly 18 inches in the area, and the cumulative departure increased from 10 inches to more than 27 inches (fig. $2 A$ ).
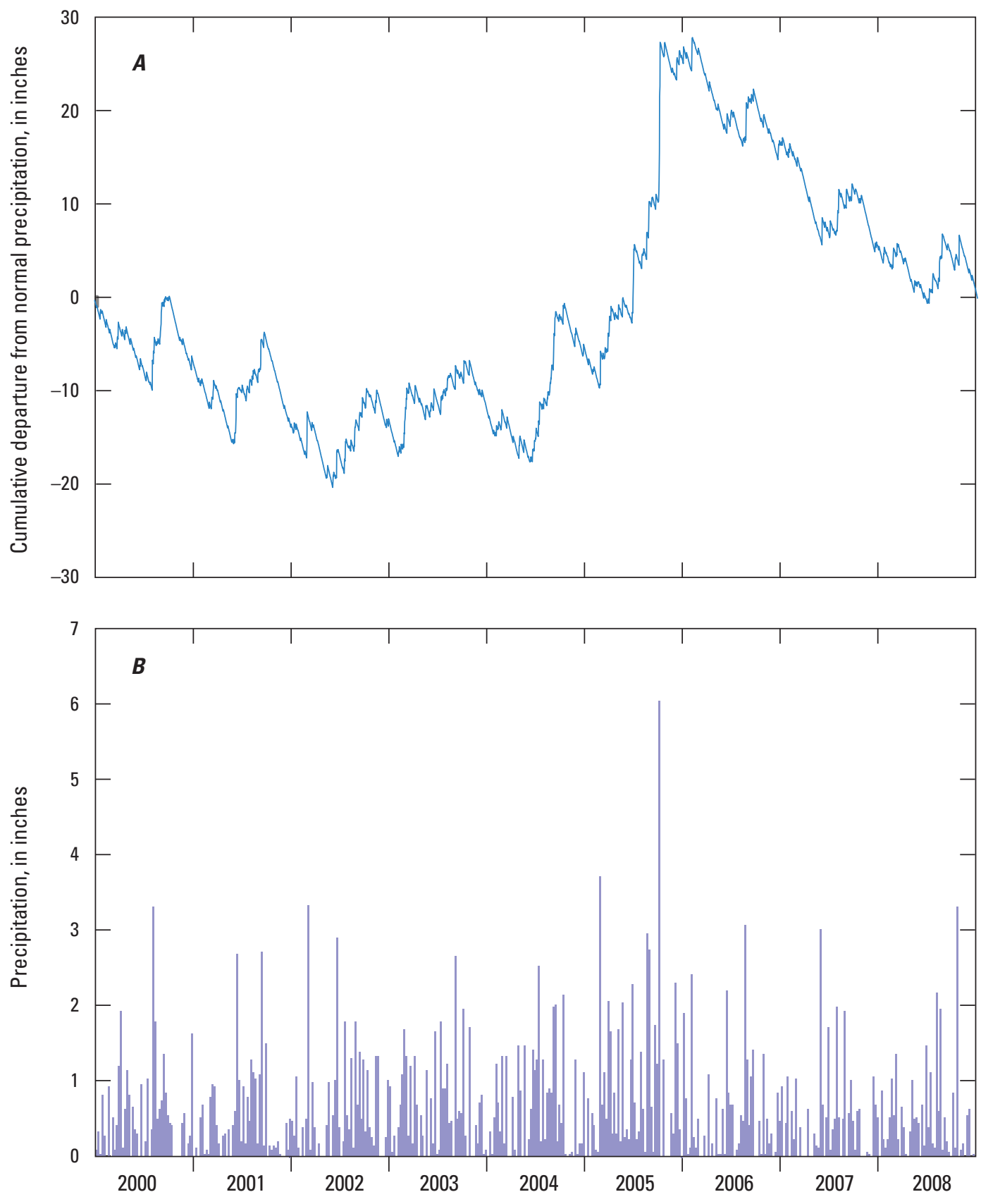

Figure 2. (A) Cumulative departure from normal precipitation and $(B)$ total daily precipitation at real-time climatic monitoring site, College of Coastal Georgia, Georgia, January 2000-December 2008 (see figure 1 for location). 


\section{Groundwater Pumpage}

The locations of groundwater pumping centers and amounts of water withdrawn from these centers may substantially affect groundwater levels in the BrunswickGlynn County area. Changes in pumping rates and the addition of new pumping centers may alter the configuration of potentiometric surfaces, reverse groundwater-flow directions, and increase seasonal and long-term fluctuations in the aquifers. During 2008, about 47 million gallons per day (Mgal/d) was withdrawn from the Upper Floridan aquifer in Glynn County, of which $8.76 \mathrm{Mgal} / \mathrm{d}$ was for public supply and $38.1 \mathrm{Mgal} / \mathrm{d}$ was for industry (Julia Fanning, U.S. Geological Survey, written commun., May 2009). According to Payne and others (2005), pumpage from the Upper Floridan aquifer in Glynn County decreased from 95.4 Mgal/d during 1980 to $61.1 \mathrm{Mgal} / \mathrm{d}$ during 2000, reflecting increased water conservation by local industry.

Historically, groundwater pumpage peaked in the early 1980 s with the majority of groundwater withdrawals used for industrial purposes (fig. 3). In calendar year 1980, Georgia-Pacific Cellulose and Ashland Aqualon (formerly Hercules-Pinova) withdrew a total of $78.3 \mathrm{Mgal} / \mathrm{d}$; groundwater withdrawals for public supply averaged $9.8 \mathrm{Mgal} / \mathrm{d}$ (L.E. Jones, U.S. Geological Survey, written commun., March 2007). At Ashland Aqualon, groundwater pumpage reached a maximum of $24 \mathrm{Mgal} / \mathrm{d}$ during 1970, and in 1982 pumpage was reduced to $14 \mathrm{Mgal} / \mathrm{d}$ due to water-conservation measures at the facility and the construction of a cooling tower (L.E. Jones, U.S. Geological Survey, written commun., March 2007). Georgia-Pacific Cellulose implemented similar water-conservation measures in the early 1990s and reduced groundwater pumpage from $58.8 \mathrm{Mgal} / \mathrm{d}$ during 1980 to $33.1 \mathrm{Mgal} / \mathrm{d}$ during 2005 (L.E. Jones, U.S. Geological Survey written commun., March, 2007). During 2001-2008, pumpage from the Upper Floridan aquifer at the Georgia-Pacific Cellulose plant decreased by nearly $5 \mathrm{Mgal} / \mathrm{d}$, while pumpage at the Ashland Aqualon plant decreased by nearly $2 \mathrm{Mgal} / \mathrm{d}$. Public supply for the City of Brunswick, Sea Island, St. Simons Island, and Jekyll Island remained at about $9 \mathrm{Mgal} / \mathrm{d}$ during the same period (Julia Fanning, U.S. Geological Survey, written commun., May 2009; fig. 3). During 1980-2005, water use by local industries (GeorgiaPacific Cellulose and Ashland Aqualon) decreased by nearly half, from $78.3 \mathrm{Mgal} / \mathrm{d}$ during 1980 to $41.1 \mathrm{Mgal} / \mathrm{d}$ during 2005 (Fanning and Trent, 2009). The reduction in pumpage had a pronounced effect on groundwater levels in the area. During 2008, pumpage estimates indicated further reductions in groundwater withdrawals from the Upper Floridan aquifer at the Georgia-Pacific Cellulose plant of $1.2 \mathrm{Mgal} / \mathrm{d}$ and decreased pumpage at the Ashland Aqualon plant by about 2.3 Mgal/d for a combined total of $37.5 \mathrm{Mgal} / \mathrm{d}$ (Julia Fanning, U.S. Geological Survey, written commun., May 2009; fig. 3).

Water use for public supply steadily increased from 1940 to 1990 and leveled off through 2008 due to the rise in population within Glynn County, which has increased from 21,920 during 1940 to 75,884 during 2008 (U.S. Census Bureau, accessed May 29, 2009, at $h t t p: / / w w w . c e n s u s . g o v /$ popest/counties/CO-EST2008-01.html). As a result, groundwater pumpage for public supply doubled from 4.4 Mgal/d during 1940 to $8.8 \mathrm{Mgal} / \mathrm{d}$ during 2008 (fig. 3). Despite the population increase, pumpage during 2008 is similar to pumpage during 1980 because of greater accountability in the water distribution systems, water conservation measures, and decreased losses due to system leakage (Keith Morgan, Brunswick-Glynn County Joint Water and Sewer Commission, oral commun., June 2009).

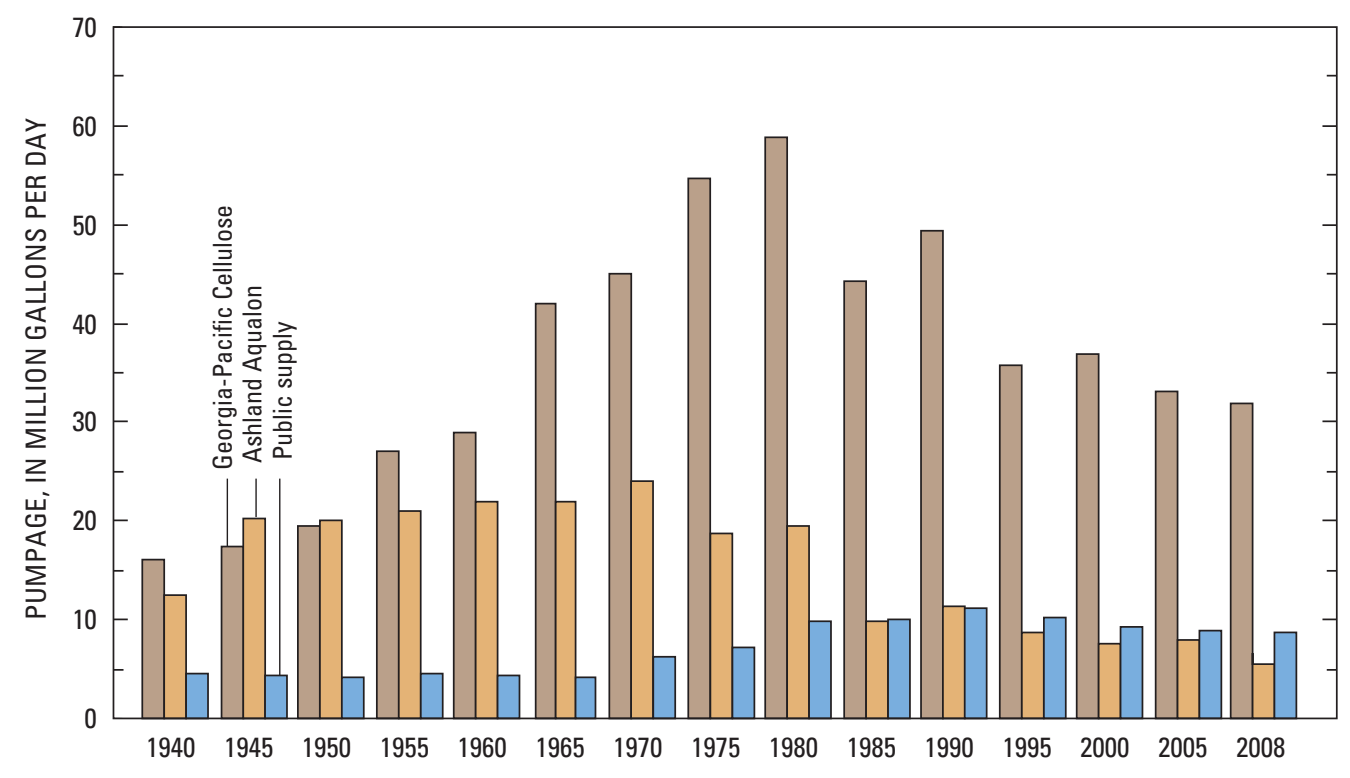

Figure 3. Major groundwater pumpage from the Upper Floridan aquifer in the Brunswick-Glynn County area, Georgia, 1940-2008. 


\section{Surficial Aquifer System}

During 2008, water levels were monitored in five wells completed in the surficial aquifer system in the BrunswickGlynn County area (fig. 4; table 1). Hydrographs for these wells are shown in figures 5-8 with the exception of well 35H076, which has insufficient record due to recent installation in early 2007. Mean water levels were mostly greater than the historical daily median in well $33 \mathrm{H} 208$ (fig. 5). Water levels were at or below historical daily median values for nearly all of 2008 in two of the four wells (wells 34H492 and 34J082, figs. 6-7), corresponding to a period of largely below-normal precipitation from late 2005 through December 2008 (fig. 2). The period of record was too short in wells 34H515 (fig. 8) and 35H076 (fig. 4) for statistical comparisons to percentile ranges. The reason for the different water-level pattern at well $33 \mathrm{H} 208$ is unknown; however, it could be related to decreased pumpage at GeorgiaPacific Cellulose since 1990 (fig. 3) as the lowest water levels correspond to a period of greater pumpage during the late 1980 s, or it could be caused by local variations in precipitation in the area.

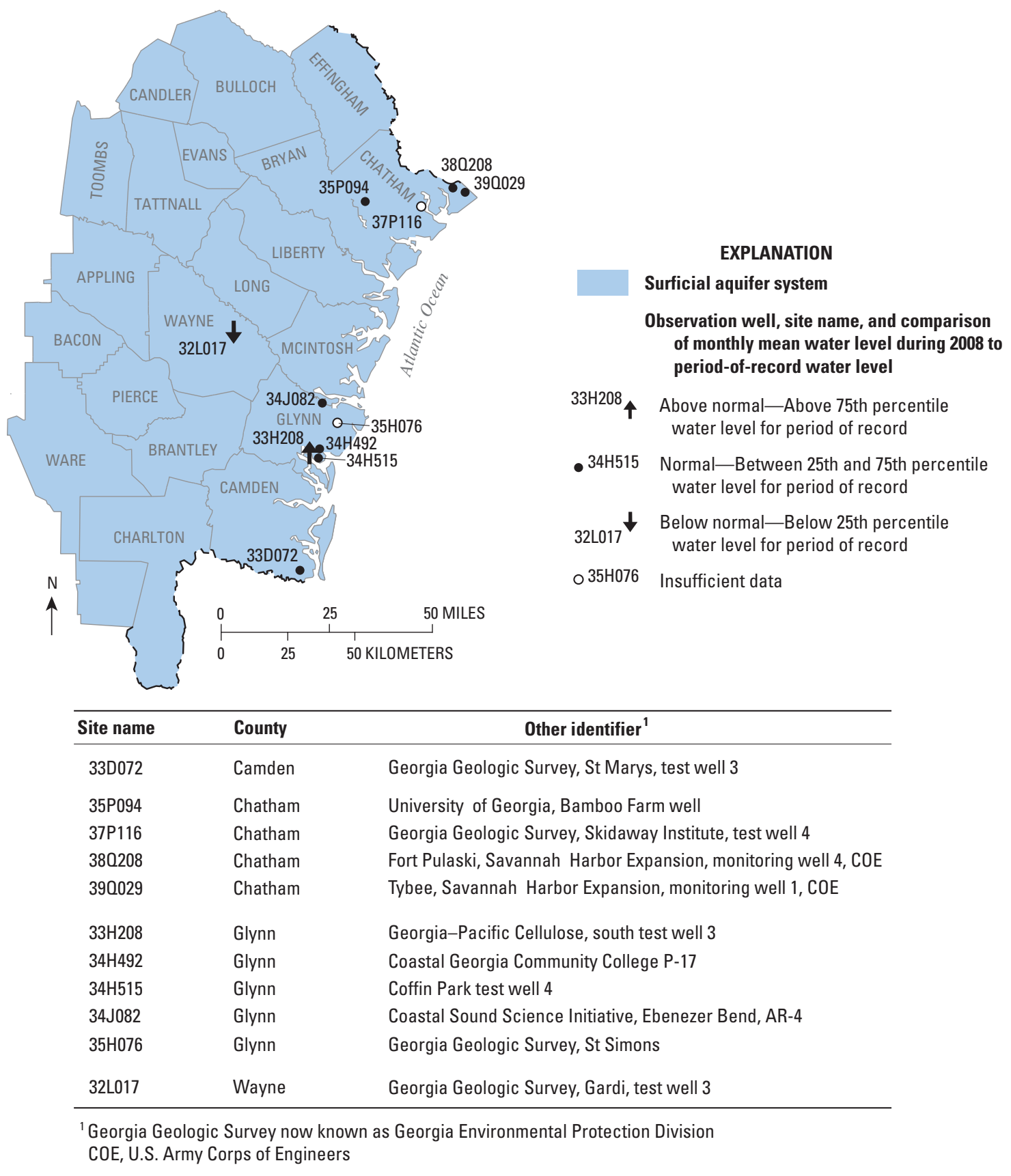

Figure 4. Groundwater levels in the surficial aquifer system in the central and southern coastal areas, Georgia, 2008. 


\section{Surficial aquifer system}

310925081312203

Glynn County

Well Depth: 155 feet Datum: 7.00 feet NGVD 29 Well Diameter: 4.00 inches
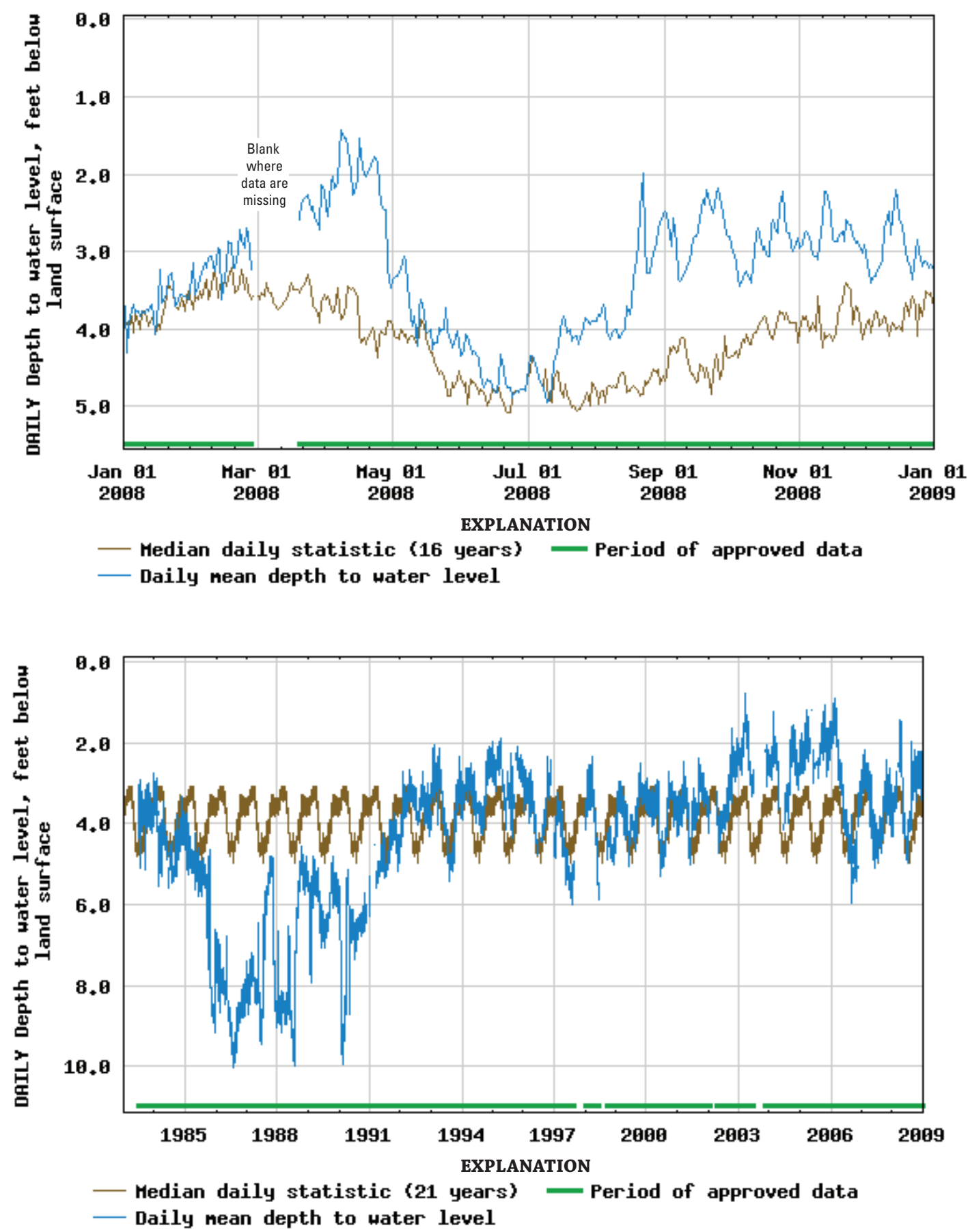

Figure 5. Periodic and daily mean water levels in well $33 \mathrm{H} 208$, surficial aquifer system, Glynn County, Georgia, 1983-2008 


\section{Surficial aquifer system}

311059081285702

Glynn County

Well Depth: 48.5 feet Datum: 12.54 feet NGVD 29 Well Diameter: 2.00 inches
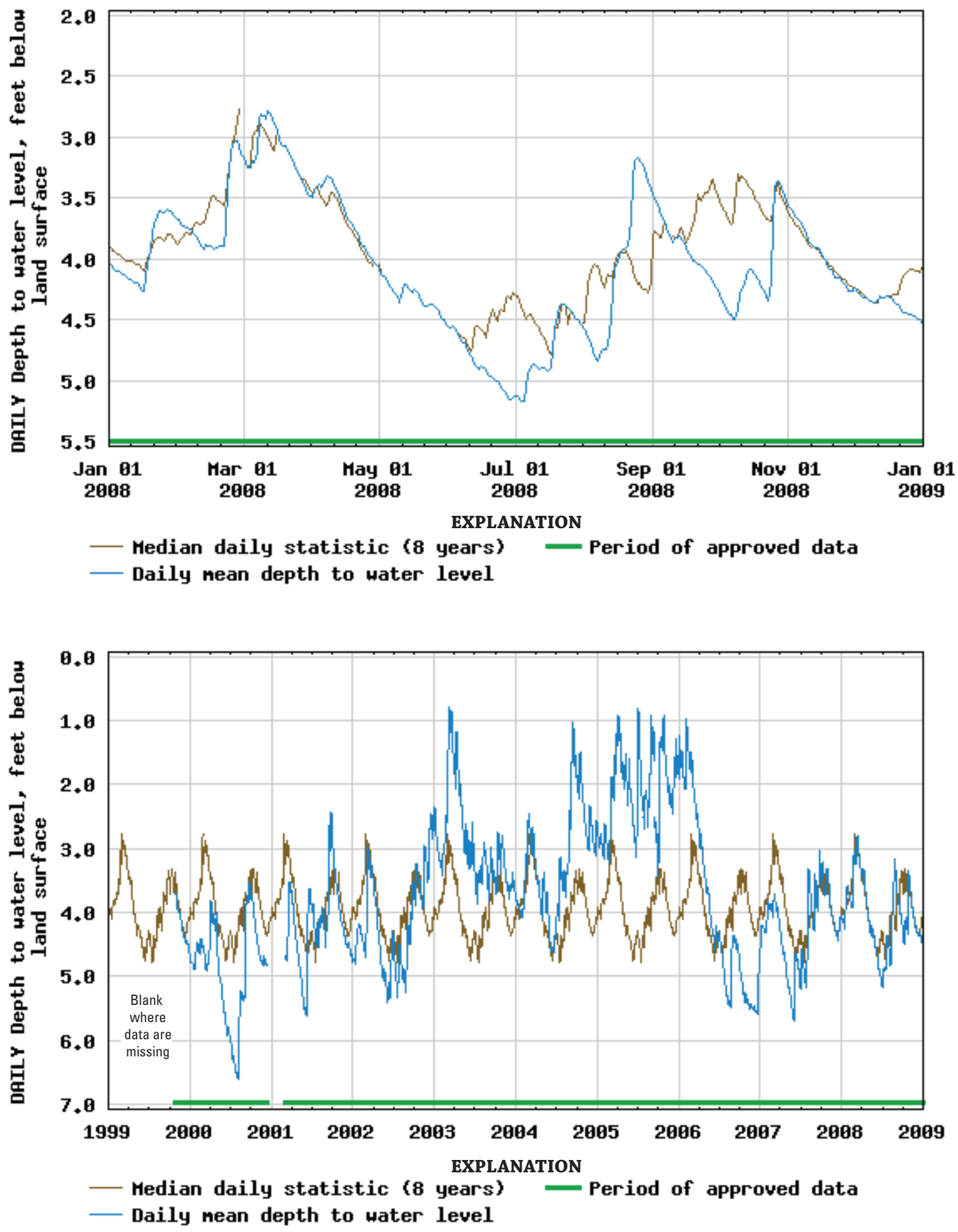

Figure 6. Periodic and daily mean water levels in well $34 \mathrm{H} 492$, surficial aquifer system, Glynn County, Georgia, 1999-2008. 


\section{Surficial aquifer system}

311909081281103

Glynn County

Well Depth: 160 feet Datum: 15.90 feet NGVD 29 Well Diameter: 4.00 inches
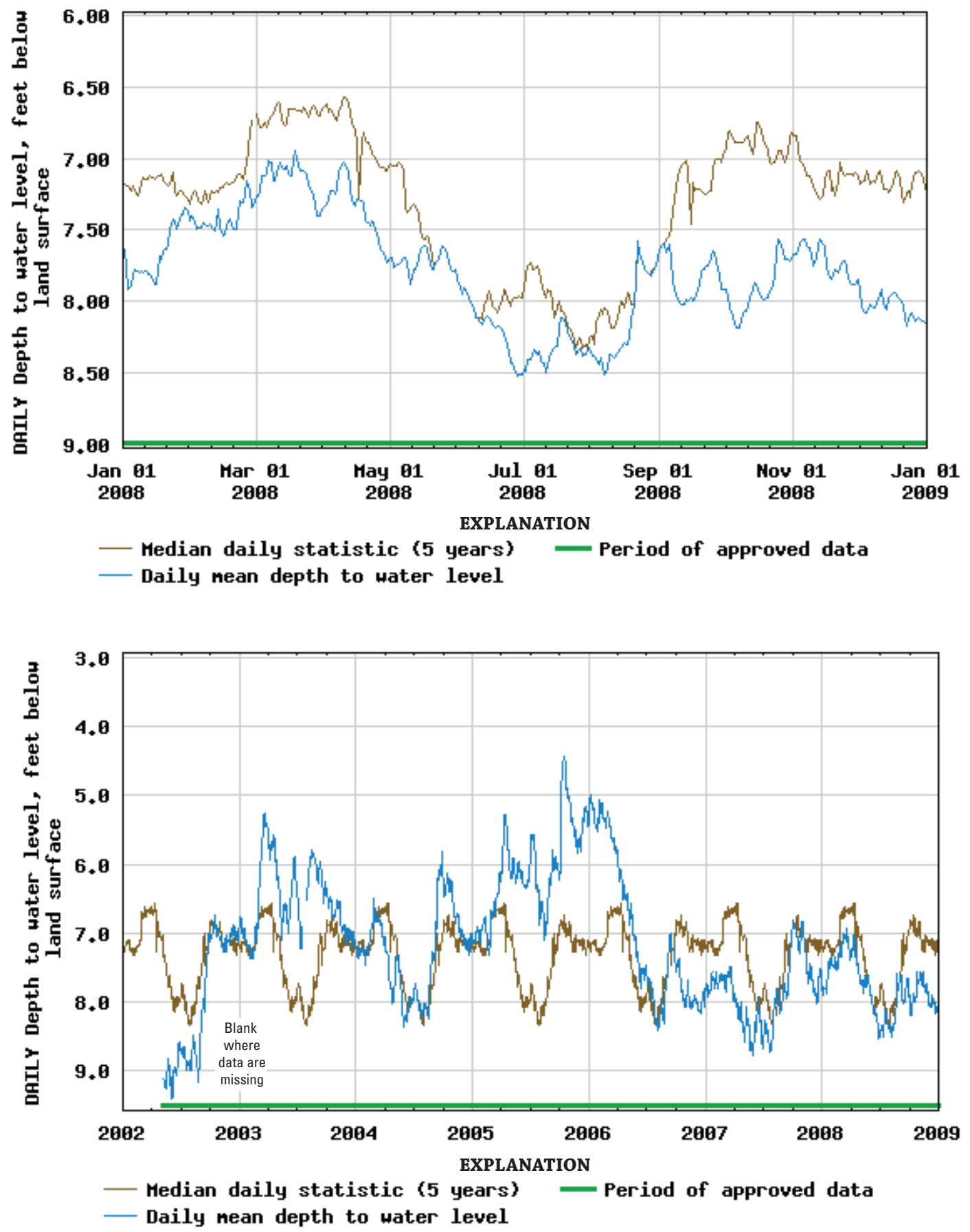

Figure 7. Periodic and daily mean water levels in well 34J082, surficial aquifer system, Glynn County, Georgia, 2002-2008. 
Surficial aquifer system

310902081284201

Glynn County

Well Depth: 200 feet
Site Name: $34 \mathrm{H} 515$

Period of Record: 2005-2008

Well Diameter: 2.00 inches
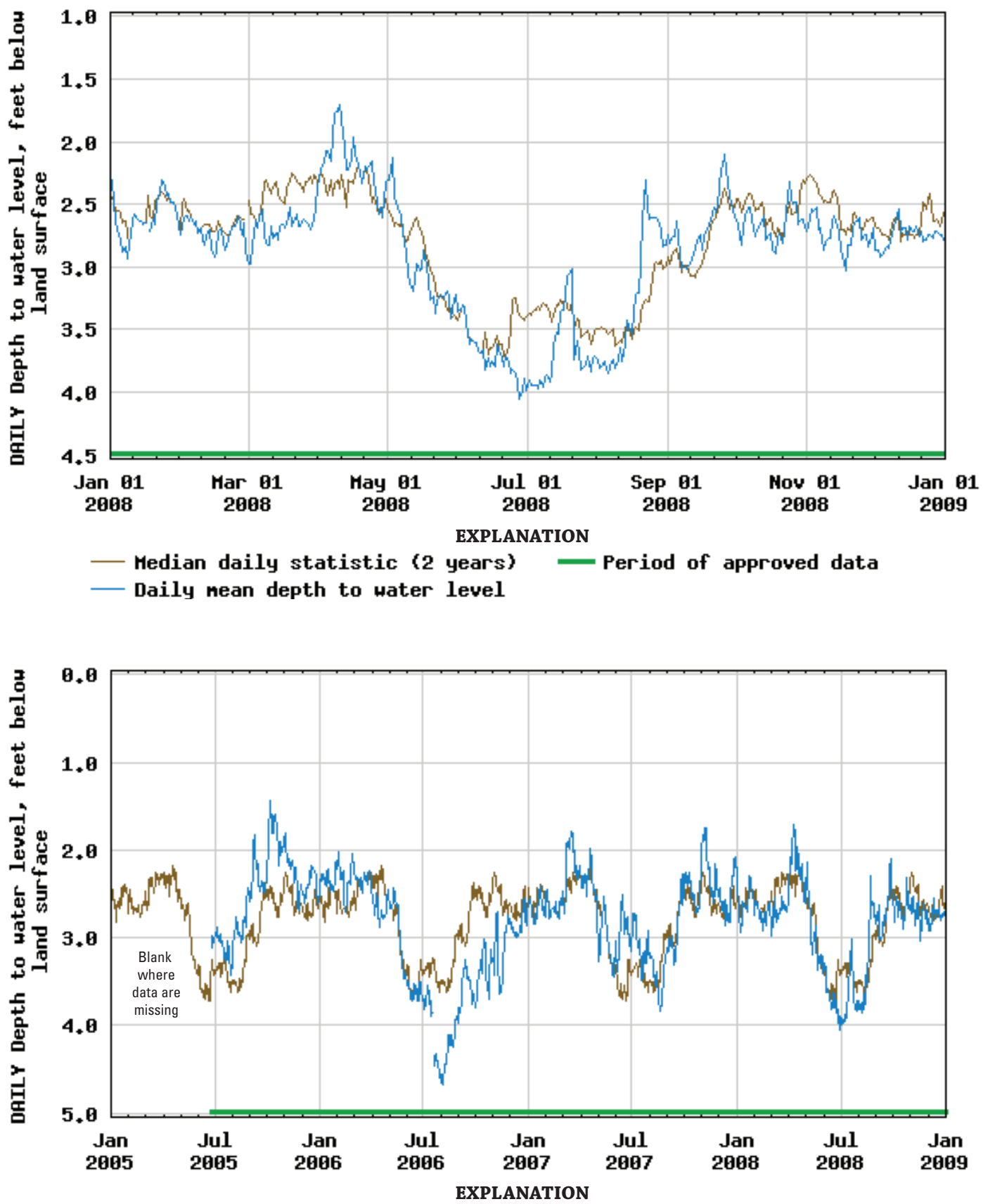

- Median daily statistic (2 years) - Period of approved data

- Daily nean depth to water level

Figure 8. Periodic and daily mean water levels in well $34 \mathrm{H} 515$, surficial aquifer system, Glynn County, Georgia, 2005-2008. 


\section{Brunswick Aquifer System}

Water levels in the Brunswick aquifer system are monitored in four wells completed in the upper Brunswick aquifer and three wells completed in the lower Brunswick aquifer (table 1; fig. 9). Hydrographs for these wells are shown in figures 10-16. The water level in six of the wells was sufficient for comparison of percentiles and comparison to normal conditions. Well $35 \mathrm{H} 077$ has a 2 -year period of record that is too short for comparison of percentiles and comparison to normal conditions. During 2008, water levels in five of the seven wells were below the historical daily median for most of the year and approached or set new historic daily minimum values in wells 33J065 (fig. 11), 34J077 (fig. 12), 34J081 (fig. 13), and 34J080 (fig. 15). These declines correspond to a period of continued drought with below-normal precipitation from late 2005 through December 2008 (fig. 2). In well 34J077 (fig. 12) at the Golden Isles development, water levels also indicate the influence of pumping in that area. Since pumping from the Brunswick aquifer system at the Golden Isle production well began during 1999, the water level has dropped about 15 feet (ft).

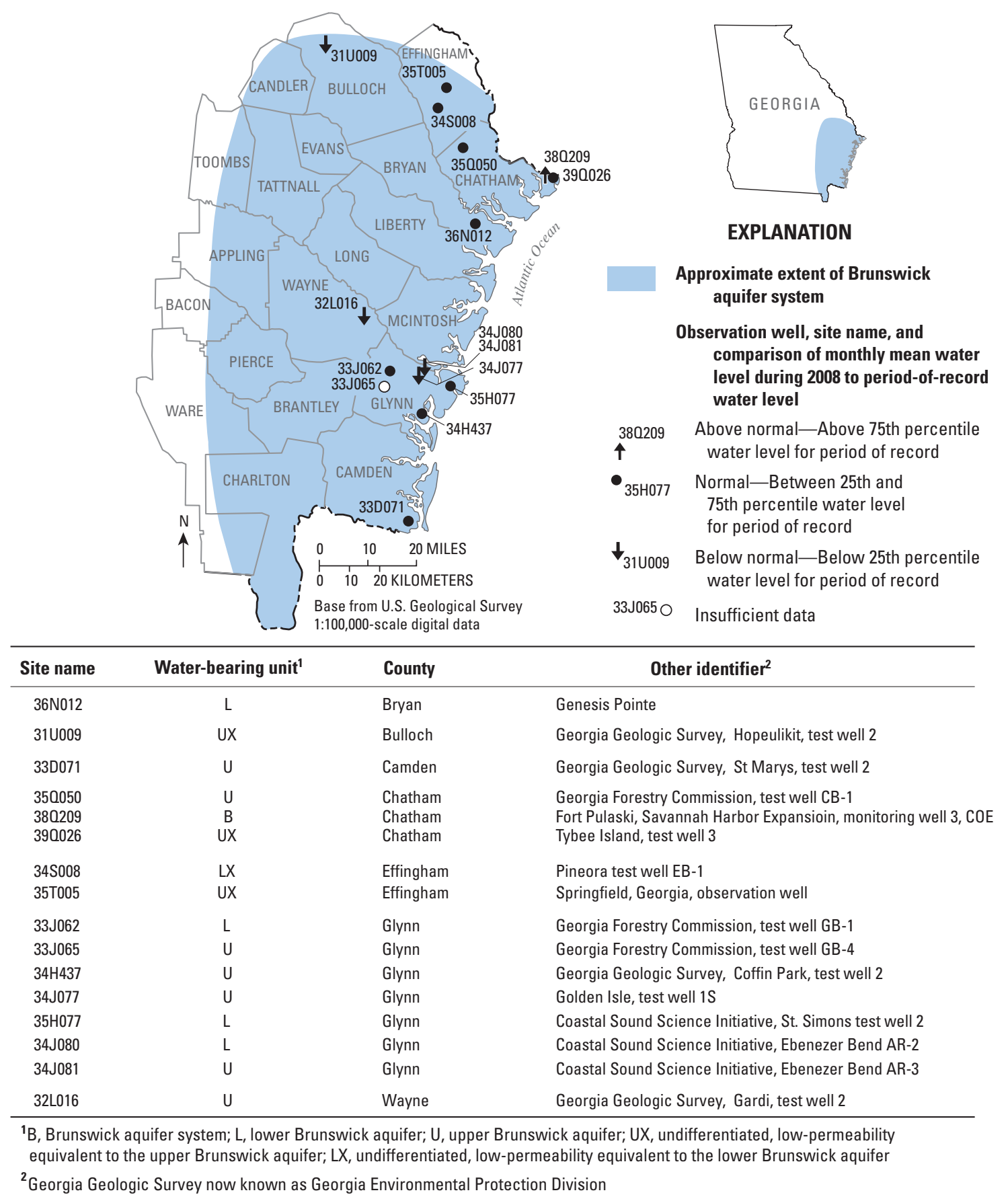

Figure 9. Groundwater levels in the Brunswick aquifer system in the central and southern coastal areas, Georgia, 2008. 
Upper Brunswick aquifer

310901081284402

Glynn County

Well Depth: 328 feet
Site Name: $34 \mathrm{H} 437$

Period of Record: 1983-2008

Well Diameter: 10.00 inches
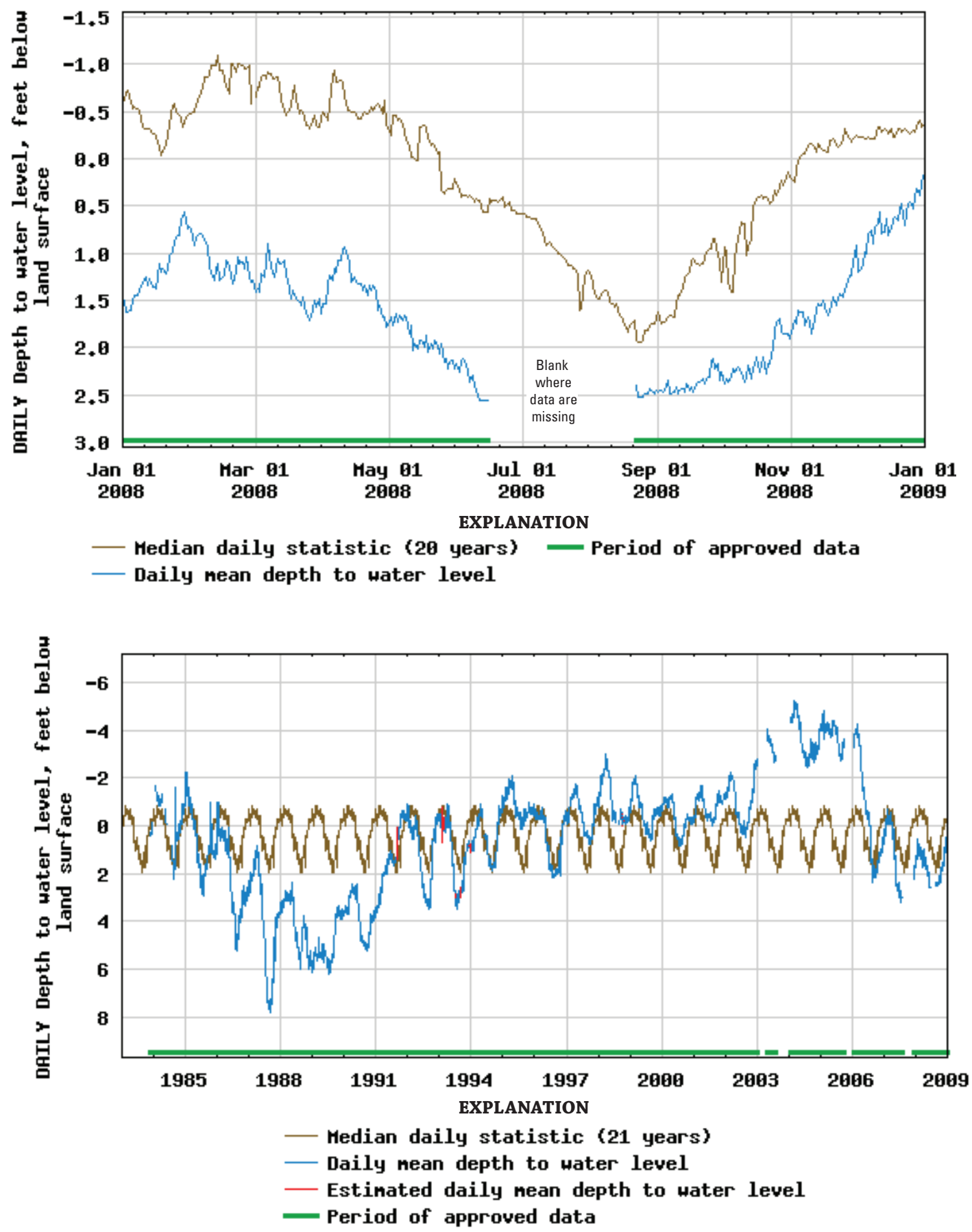

Figure 10. Periodic and daily mean water levels in well 34H437, upper Brunswick aquifer, Glynn County, Georgia, 1983-2008. 


\section{Upper Brunswick aquifer}

311530081363904

Glynn County

Well Depth: 412 feet Datum: 12 feet NGVD 29 Well Diameter: 6.00 inches
Site Name: 33J065

Period of Record: 2001-2008
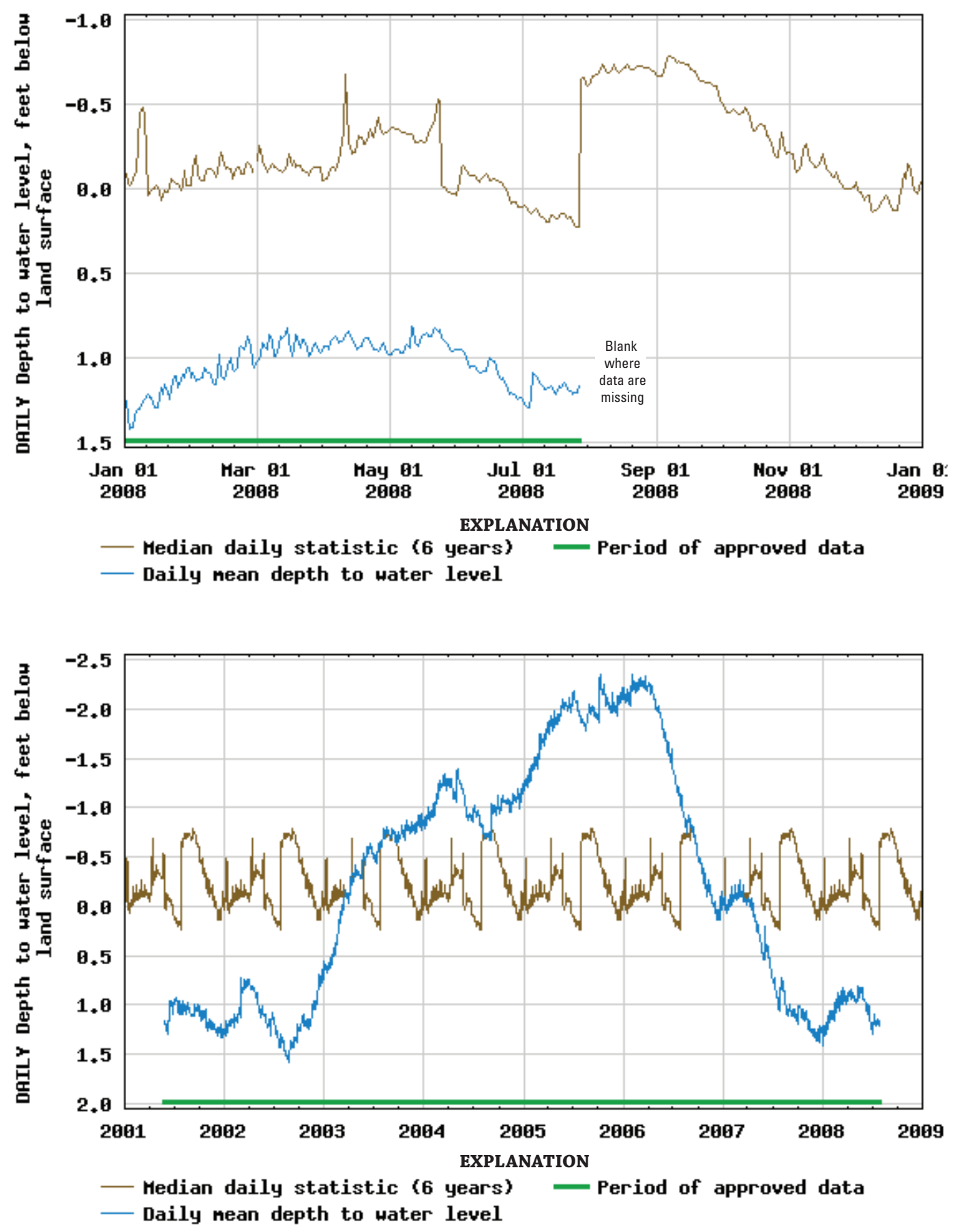

Figure 11. Periodic and daily mean water levels in well 33J065, upper Brunswick aquifer, Glynn County, Georgia, 2001-2008. 
Upper Brunswick aquifer

311711081283002

Glynn County

Well Depth: 390 feet
Site Name: 34J077

Period of Record: 1998-2008

Datum: 15 feet NGVD 29 Well Diameter: 4.00 inches
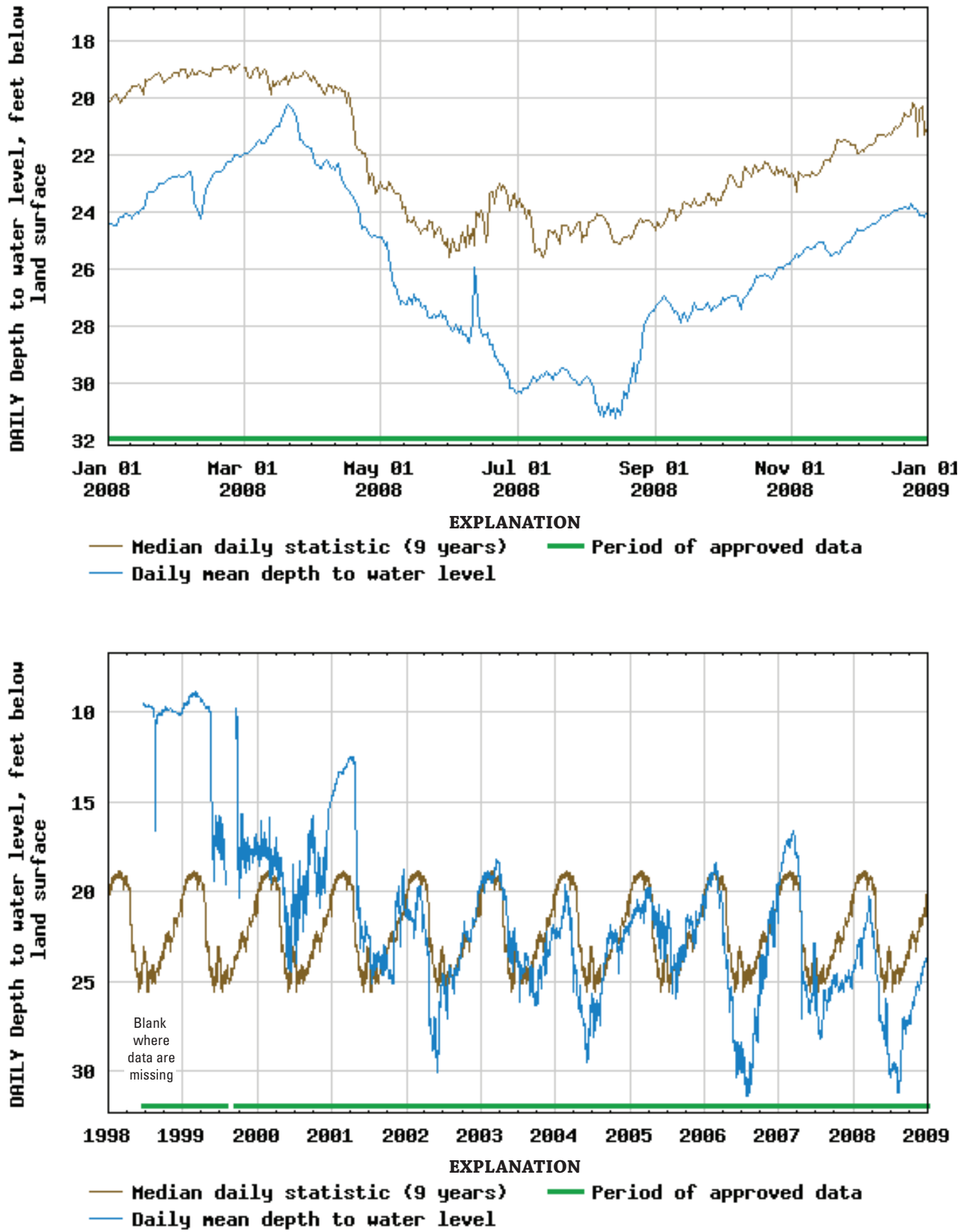

Figure 12. Periodic and daily mean water levels in well 34J077, upper Brunswick aquifer, Glynn County, Georgia, 1998-2008. 


\section{Upper Brunswick aquifer}

311909081281102

Glynn County

Well Depth: 435 feet Datum: 14.68 feet NGVD 29 Well Diameter: 4.00 inches
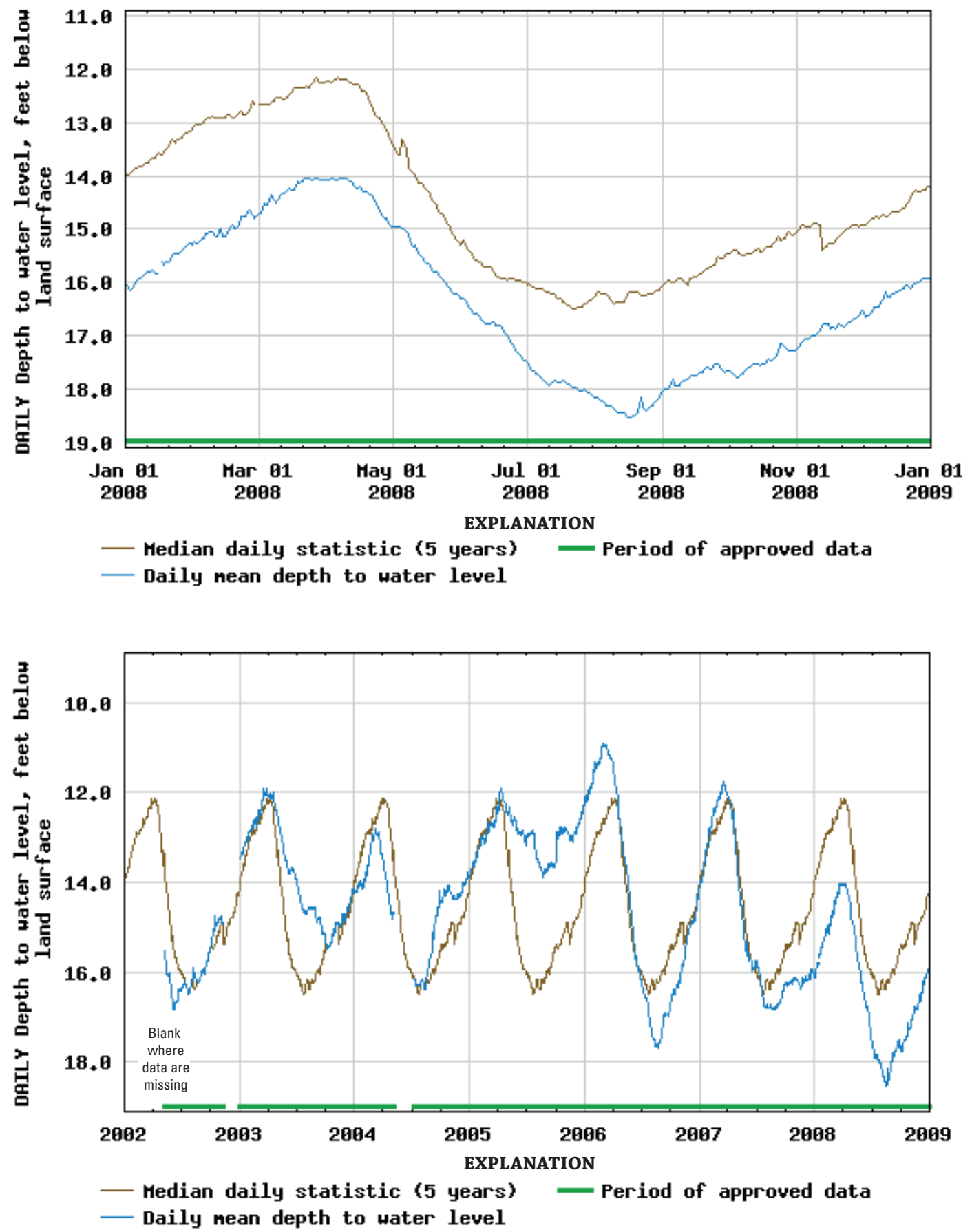

Figure 13. Periodic and daily mean water levels in well 34J081, upper Brunswick aquifer, Glynn County, Georgia, 2002-2008. 
Lower Brunswick aquifer

311530081363901

Glynn County

Well Depth: 500 feet Datum: 12.00 feet NGVD 29 Well Diameter: 6.00 inches
Site Name: 33J062

Period of Record: 2001-2008
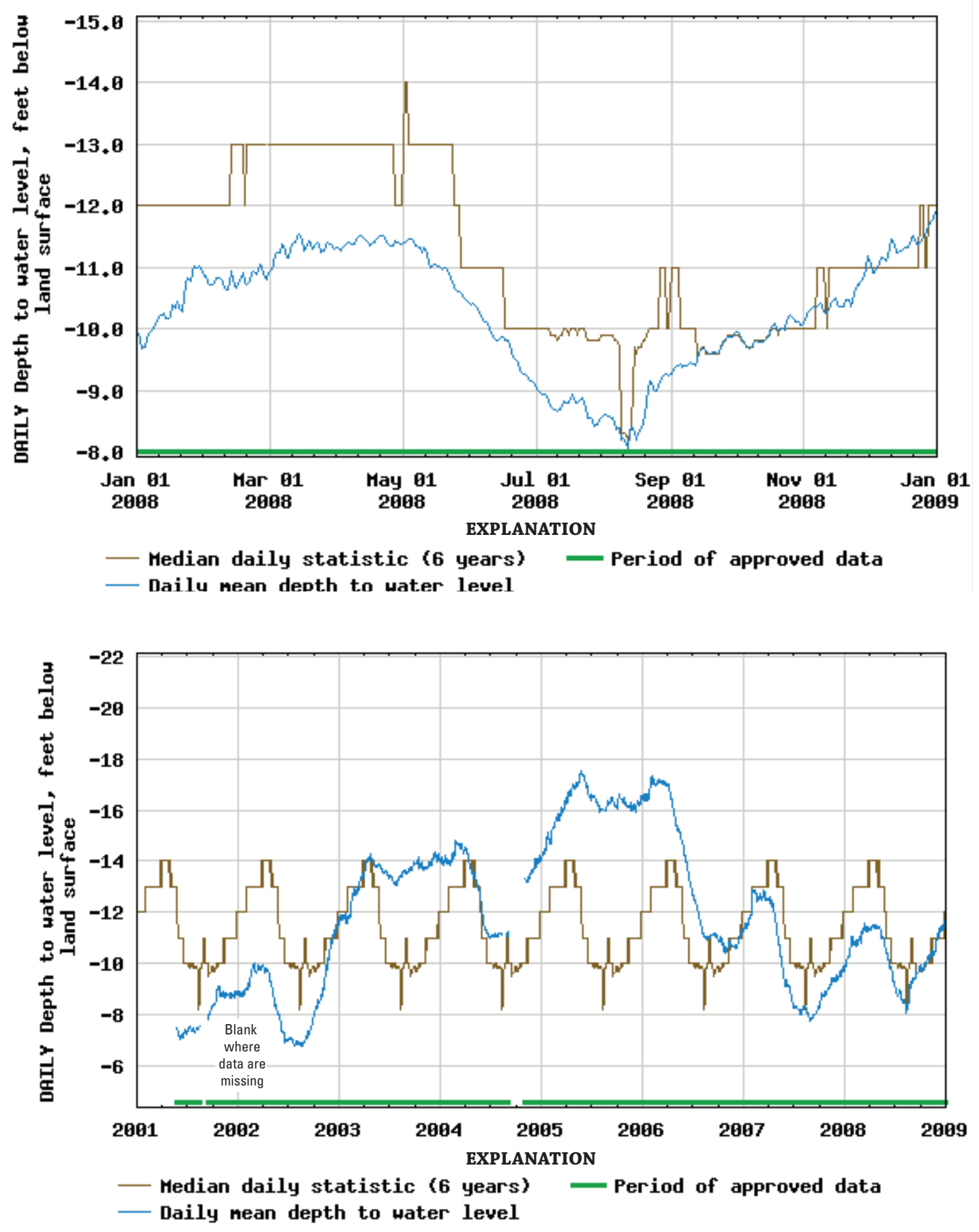

Figure 14. Periodic and daily mean water levels in well 33J062, lower Brunswick aquifer, Glynn County, Georgia, 2001-2008. 


\section{Lower Brunswick aquifer}

311909081281101

Glynn County
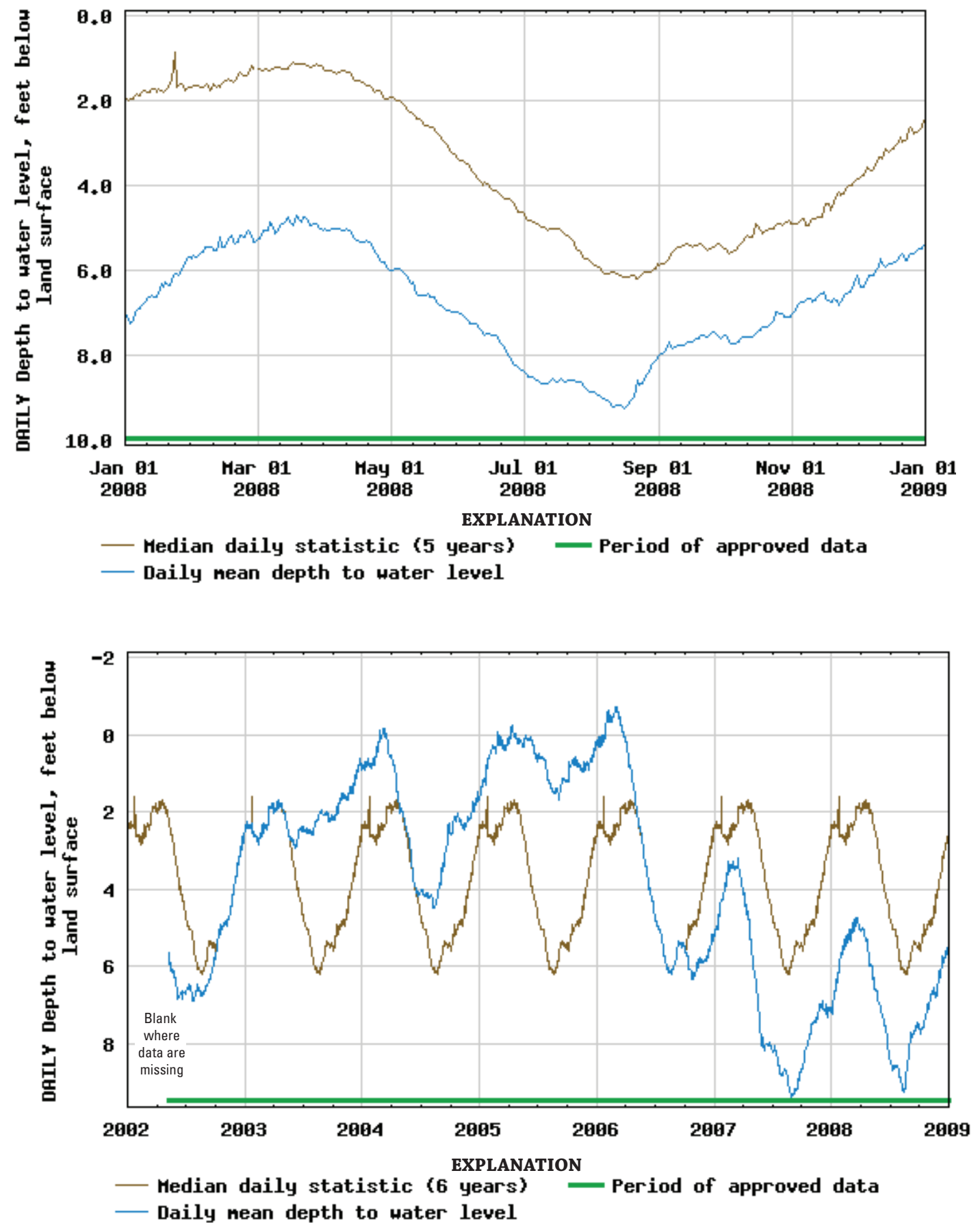

Figure 15. Periodic and daily mean water levels in well 34J080, lower Brunswick aquifer, Glynn County, Georgia, 2002-2008. 
Lower Brunswick aquifer

311456081210504

Glynn County

Well Depth: 537 feet
Site Name: 35H077

Period of Record: 2005-2008

Datum: 20 feet NGVD 29 Well Diameter: 6.00 inches
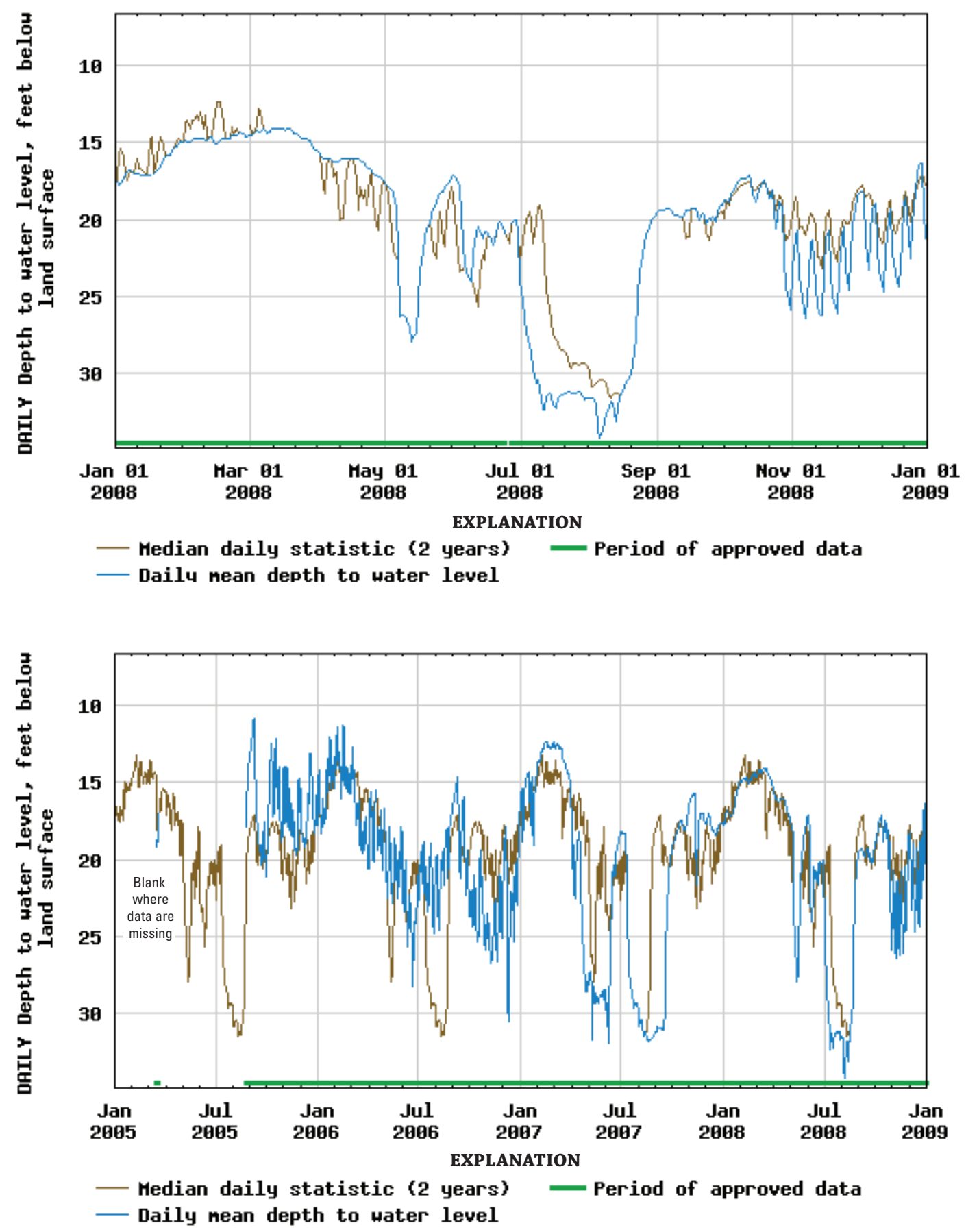

Figure 16. Periodic and daily mean water levels in well 35H077, lower Brunswick aquifer, Glynn County, Georgia, 2005-2008. 


\section{Floridan Aquifer System}

Water levels in the Floridan aquifer system in the Brunswick-Glynn County area are continuously monitored in 12 wells completed in the Upper Floridan aquifer (fig. 17; table 1) and in 7 wells completed in the Lower Floridan aquifer. Hydrographs for six of the Upper Floridan wells are shown in figures 18-23, and locations and hydrographs for seven Lower Floridan wells are shown in figures $24-31$. The period of record was too short to display hydrographs for wells $35 \mathrm{H} 070,33 \mathrm{H} 324,33 \mathrm{H} 325,34 \mathrm{H} 504$, 34H505, and 34H514 (Upper Floridan aquifer) and 35H068 (Lower Floridan aquifer), which were installed in 2007 (fig. 1; table 1). Data for wells 33H324, 33H325, 34H504, $34 \mathrm{H} 505$, and $34 \mathrm{H} 514$ are included in the section on real-time groundwater monitoring stations.

Although not influenced directly by precipitation, water levels in the Floridan aquifer system generally declined during 2007-2008, corresponding to increased pumping demand. Despite this decline, water levels in 5 of the 12 wells completed in the Upper Floridan aquifer were at or above historical daily median levels during most of 2008, reflecting the continuing effect of pumping reductions in the coastal area since the 1990s (wells 33H133, 33H207, 33H127, $34 \mathrm{H} 334$, and 34H371). The period of record is too short to allow for statistical comparisons for six Upper Floridan aquifer wells (33H324, 33H325, 34H504, 34H505, 34G033, and $35 \mathrm{H} 070)$.

In addition to continuous recorders, synoptic water-level measurements were collected in 21 wells completed in the Upper Floridan aquifer during July 2008, and a potentiometric-surface map was prepared using 19 of the water-level measurements (fig. 17). The map indicates that the principal directions of groundwater flow during 2008 remained from south to north and from east to west, following the gradient created by large industrial withdrawals in the northern and western parts of the Brunswick area (fig. 17).

Water levels in the Lower Floridan aquifer also declined during 2007 and 2008 in response to increased pumping (fig. 24). Water levels in five of the eight wells (33H188, $33 \mathrm{H} 206,33 \mathrm{~J} 044,34 \mathrm{H} 391$, and 34H436) were at or below historical daily median levels during most of the year. 

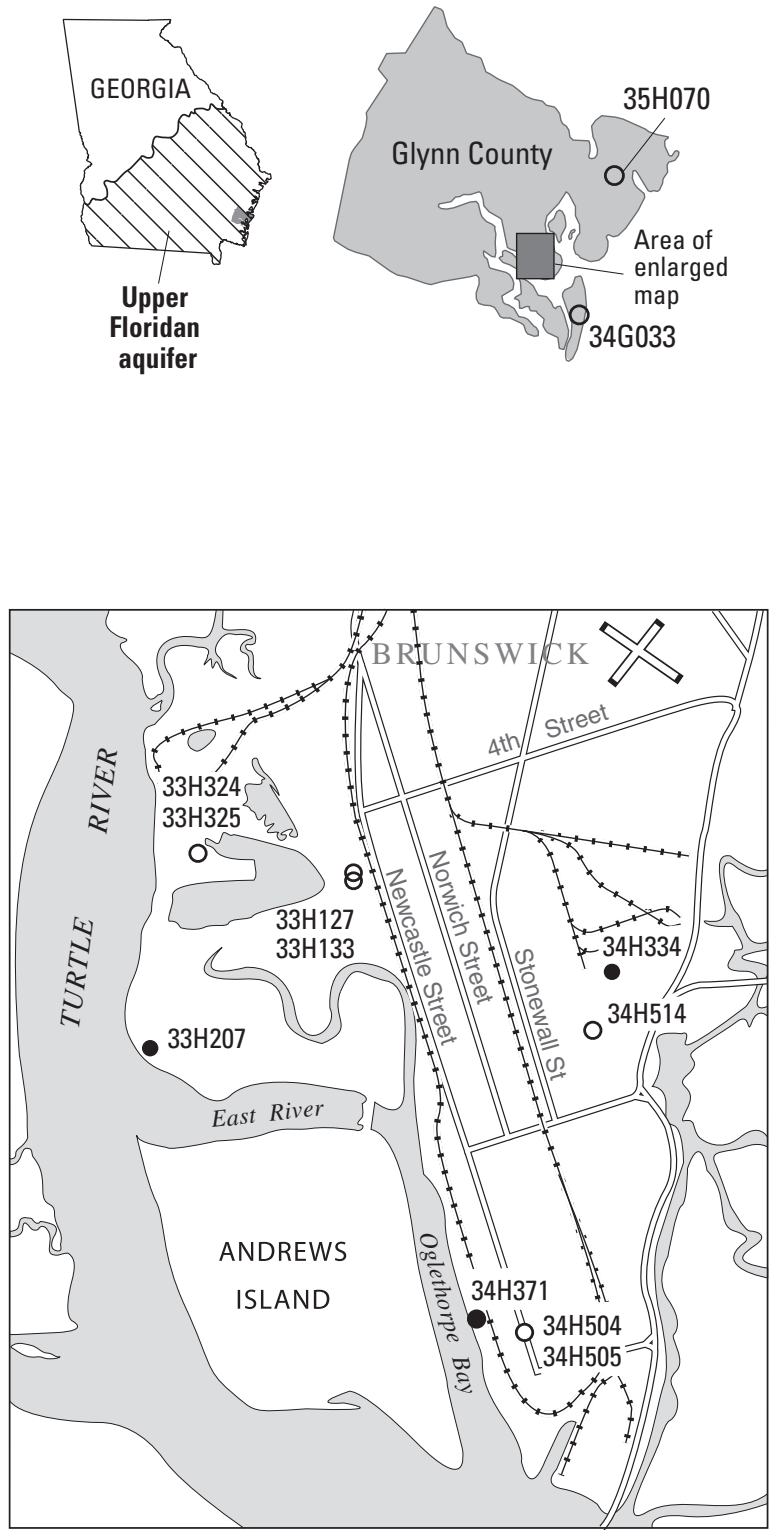

Base from U.S. Geological Survey 1:100,000-scale digital data

\begin{tabular}{|c|c|c|}
\hline Site name & County & Other identifier $^{1}$ \\
\hline $33 \mathrm{H} 127$ & Glynn & U.S. Geological Survey, test well 3 \\
\hline $33 \mathrm{H} 133$ & Glynn & U.S. Geological Survey, test well 6 \\
\hline $33 \mathrm{H} 207$ & Glynn & Georgia-Pacific, south test well 2 \\
\hline $33 \mathrm{H} 324$ & Glynn & $\begin{array}{l}\text { Georgia-Pacific, Lower water-bearing zone } \\
\text { Coastal Sound Science Initiative }\end{array}$ \\
\hline $33 \mathrm{H} 325$ & Glynn & $\begin{array}{l}\text { Georgia-Pacific, Upper water-bearing zone } \\
\text { Coastal Sound Science Initiative }\end{array}$ \\
\hline $34 \mathrm{G} 033$ & Glynn & Jekyll Island No. 9 \\
\hline $34 \mathrm{H} 334$ & Glynn & U.S. Geological Survey, test well 4 \\
\hline $34 \mathrm{H} 371$ & Glynn & U.S. Geological Survey, test well 11 \\
\hline $34 \mathrm{H} 504$ & Glynn & Southside Baptist Church \\
\hline $34 \mathrm{H} 505$ & Glynn & Southside Baptist Church \\
\hline $34 \mathrm{H} 514$ & Glynn & City of Brunswick, Perry Park \\
\hline $35 \mathrm{H} 070$ & Glynn & GGS, St. Simons Upper Floridan \\
\hline
\end{tabular}

${ }^{1}$ Georgia Geologic Survey (GGS) now known as Georgia Environmental Protection Division

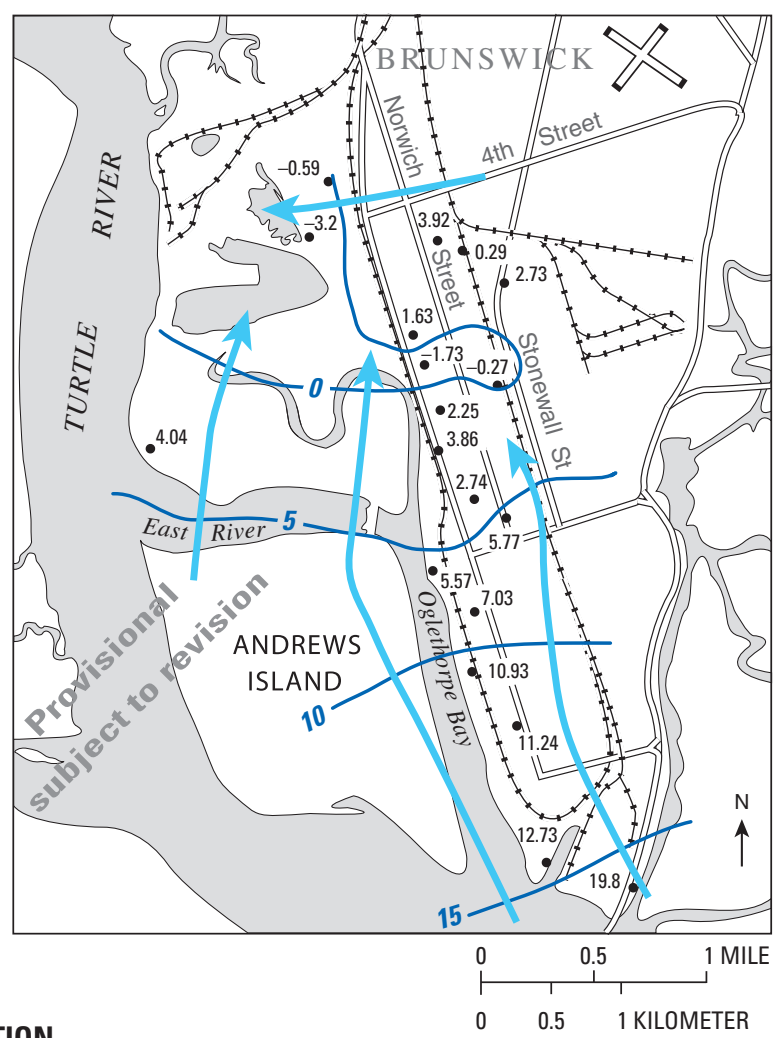

EXPLANATION

Observation well, site name, and comparison of mean annual water level during 2008 to period-of-record water level

- 33H207 Normal-Between 25th and 75th percentile water level for period of record

o $33 \mathrm{H} 325$ No data or insufficient data
- $15-$ Potentiometric contour - Shows altitude at which water level would have stood in tightly cased wells in the Upper Floridan aquifer, July 2008. Contour interval 5 feet. Datum is NAVD 88

General direction of groundwater flow

Figure 17. Groundwater level monitoring network and potentiometric surfaces for the Upper Floridan aquifer in the Brunswick-Glynn County area, July 2008. 


\section{Upper Floridan aquifer}

311007081301702

Glynn County

Well Depth: 790 feet Datum: 6.71 feet NGVD 29 Well Diameter: 4.00 inches
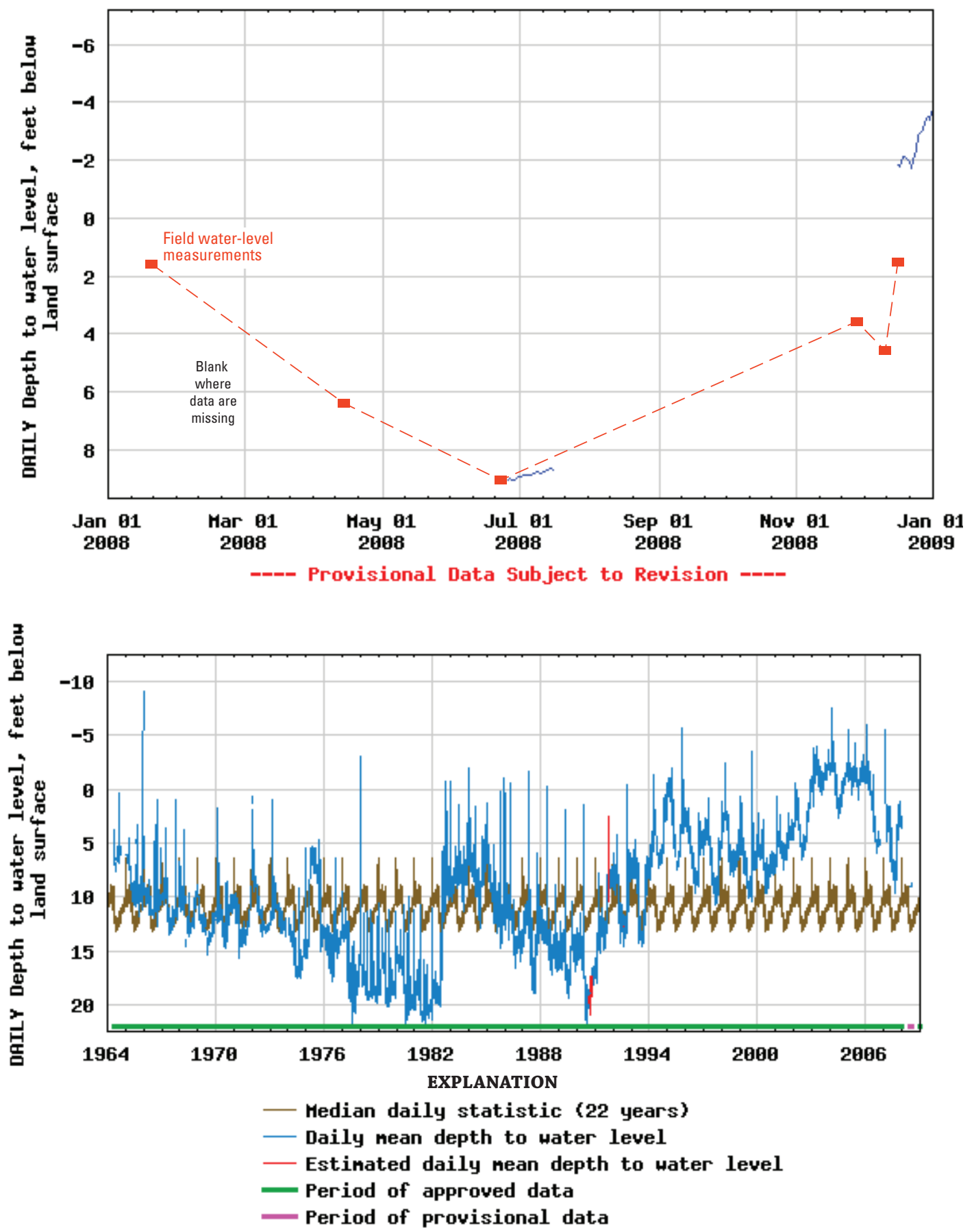

Figure 18. Periodic and daily mean water levels in well 33H133, Upper Floridan aquifer, Glynn County, Georgia, 1964-2008. 
Upper Floridan aquifer

310925081312202

Glynn County

Site Name: 33H207

Well Depth: 720 feet Datum: 7.00 feet NGVD 29 Well Diameter: 4.00 inches
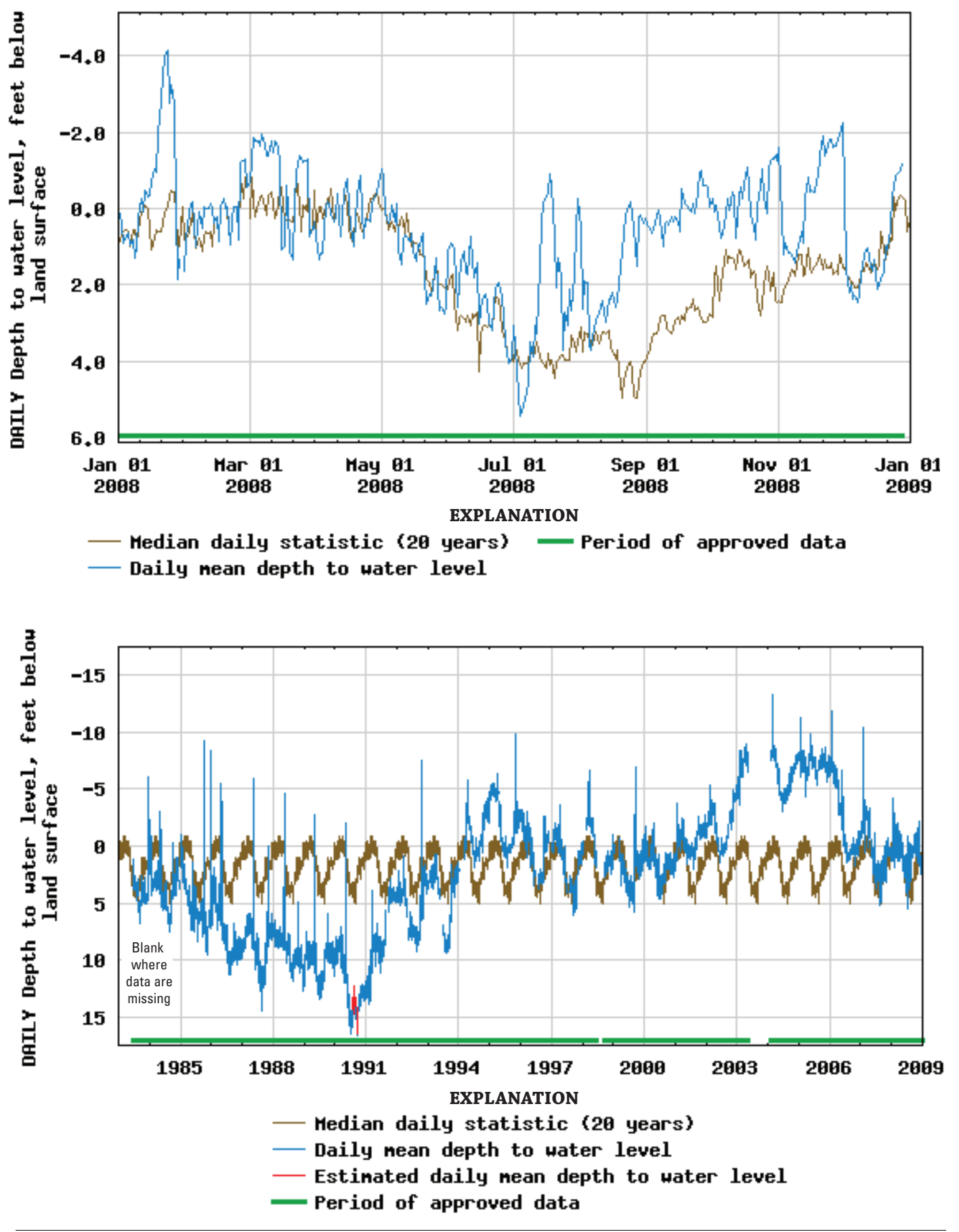

Figure 19. Periodic and daily mean water levels in well 33H207, Upper Floridan aquifer, Glynn County, Georgia, 1983-2008. 


\section{Upper Floridan aquifer}

310418081244701

Glynn County
Site Name: $34 \mathrm{G033}$

Period of Record: 2004-2008

Well Diameter: 8.00 inches
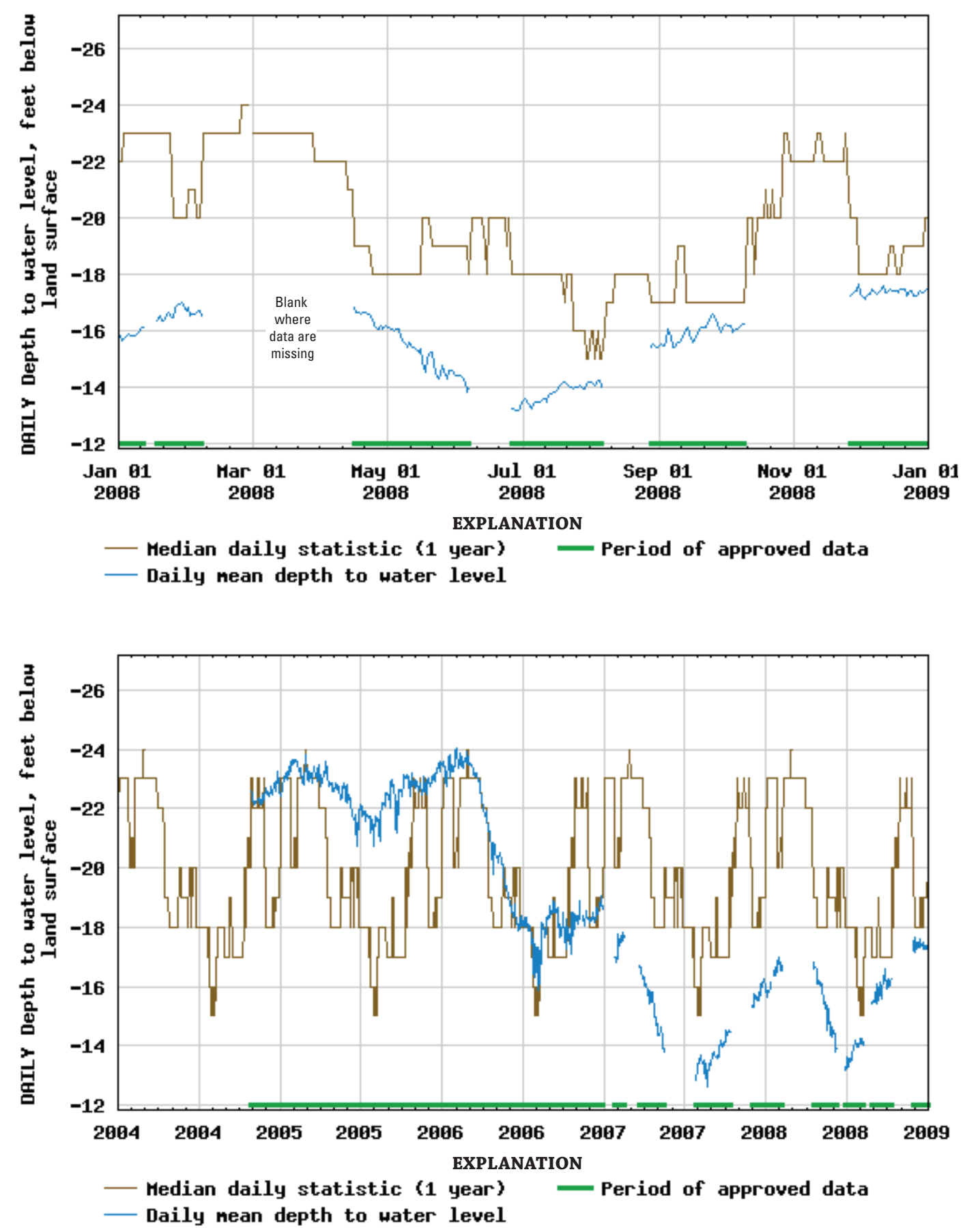

Figure 20. Periodic and daily mean water levels in well 34G033, Upper Floridan aquifer, Glynn County, Georgia, 2004-2008. 


\section{Upper Floridan aquifer}

311007081301701

Glynn County

Site Name: 33H127

Well Depth: 952 feet Datum: 6.15 feet NGVD 29 Well Diameter: 7.00 inches

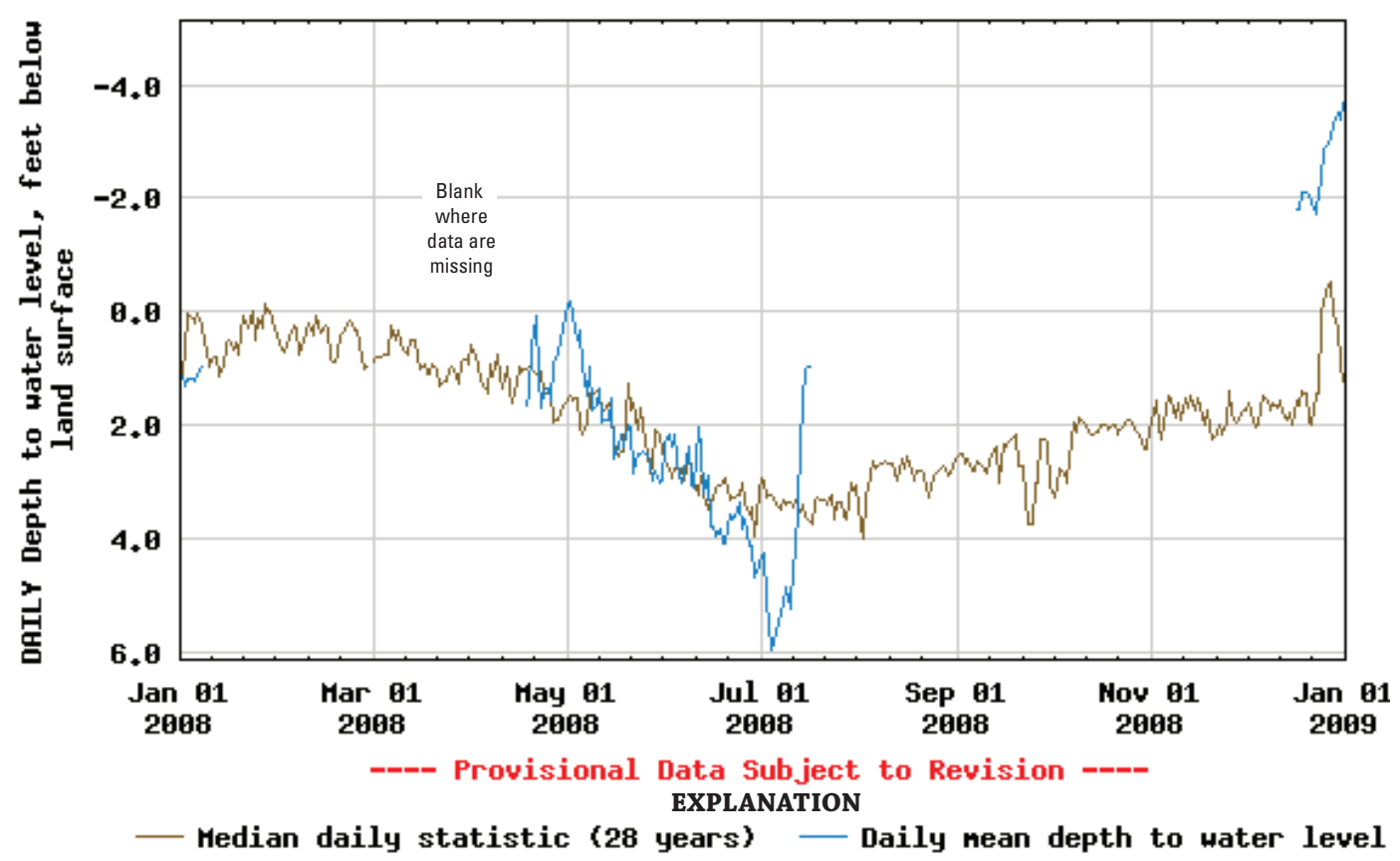

נים

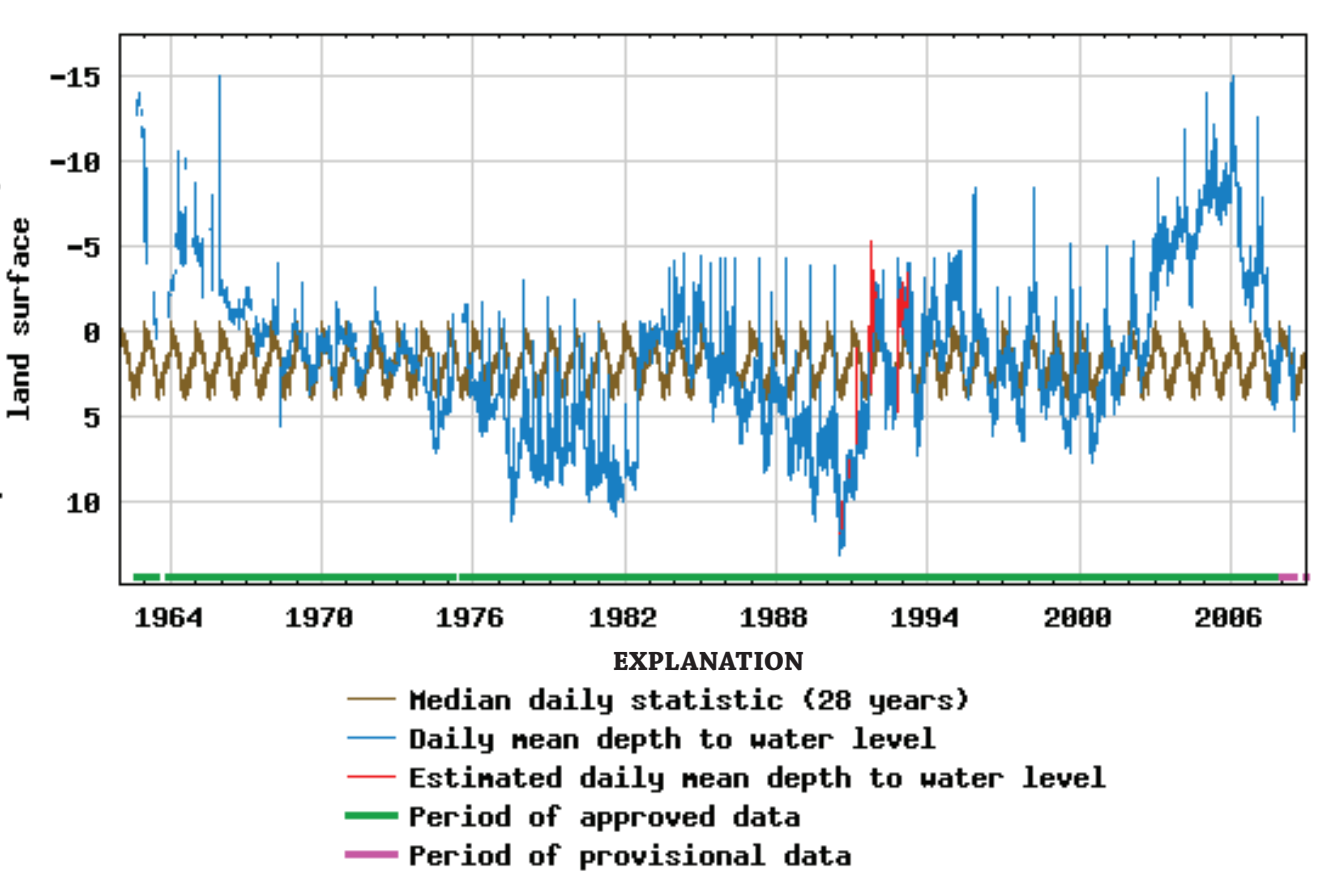

Figure 21. Periodic and daily mean water levels in well 33H127, Upper Floridan aquifer, Glynn County, Georgia, 1962-2008. 
Upper Floridan aquifer

310938081285301

Glynn County

Well Depth: 980 feet Datum: 833 feet NGVD 29 Well Diameter: 4.00 inches
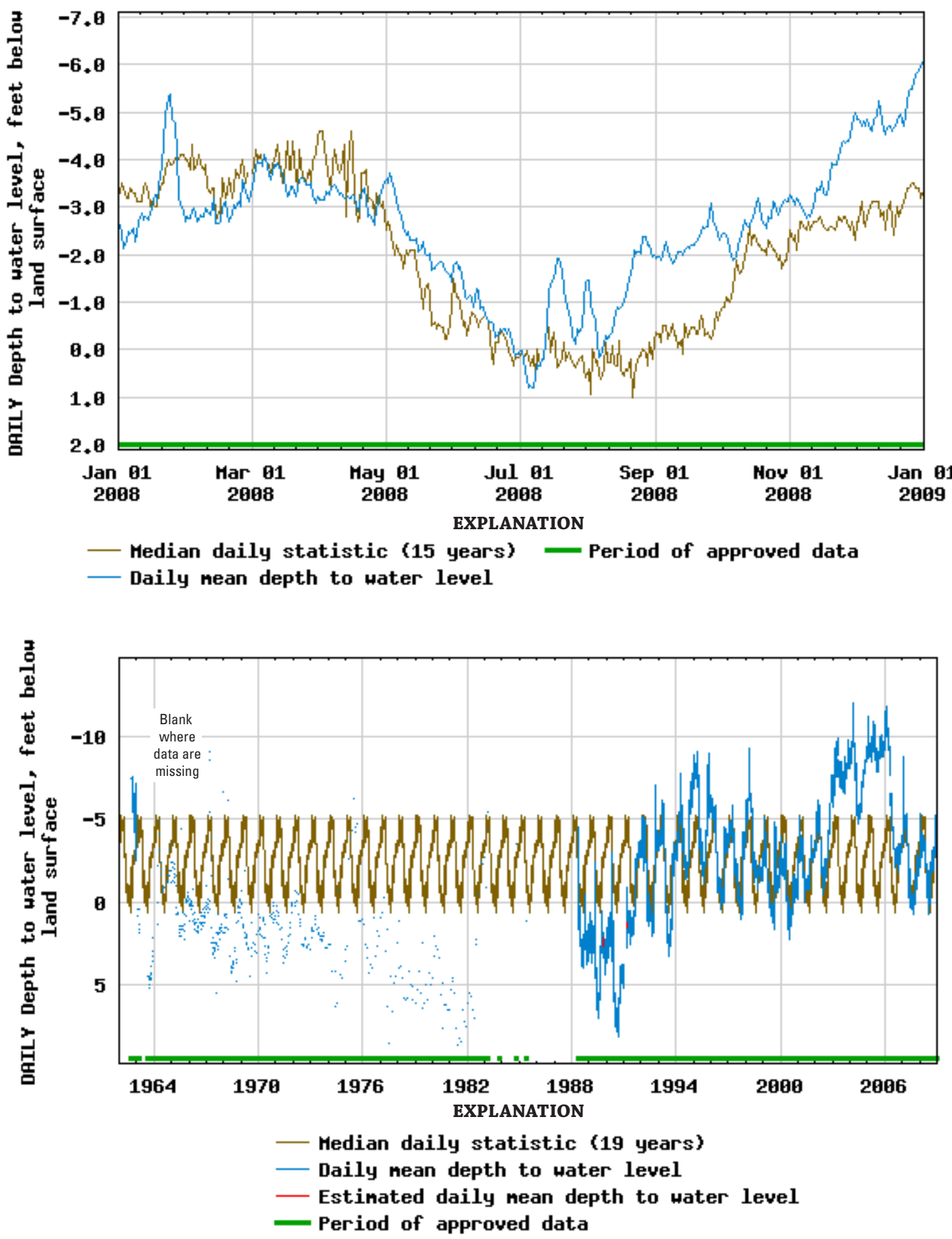

Figure 22. Periodic and daily mean water levels in well 34H334, Upper Floridan aquifer, Glynn County, Georgia, 1962-2008. 


\section{Upper Floridan aquifer}

310818081293701

Glynn County

Site Name: $34 \mathrm{H} 371$

Well Depth: 700 feet Datum: 9.49 feet NGVD 29 Well Diameter: 200 inches
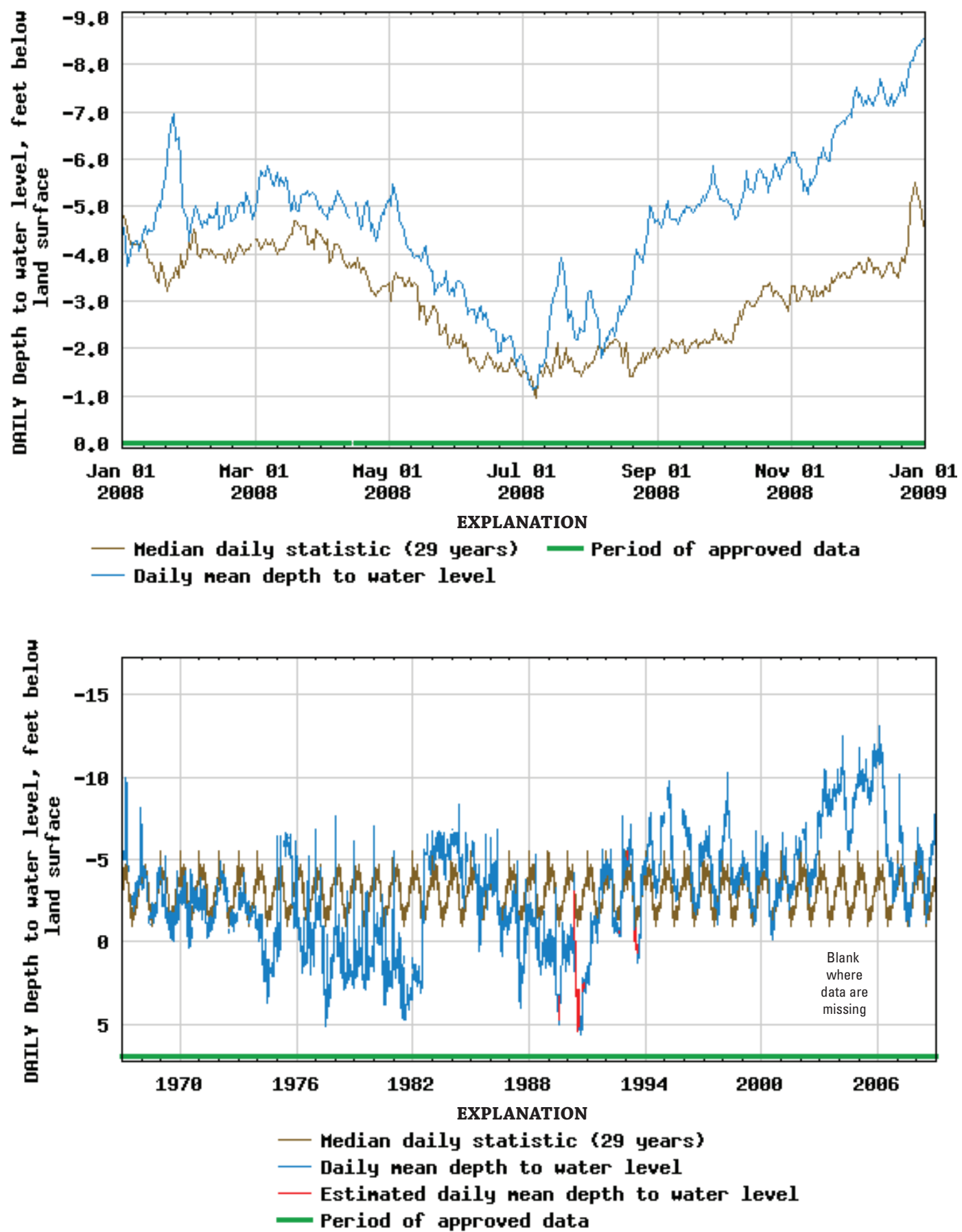

Figure 23. Periodic and daily mean water levels in well 34H371, Upper Floridan aquifer, Glynn County, Georgia, 1967-2008. 

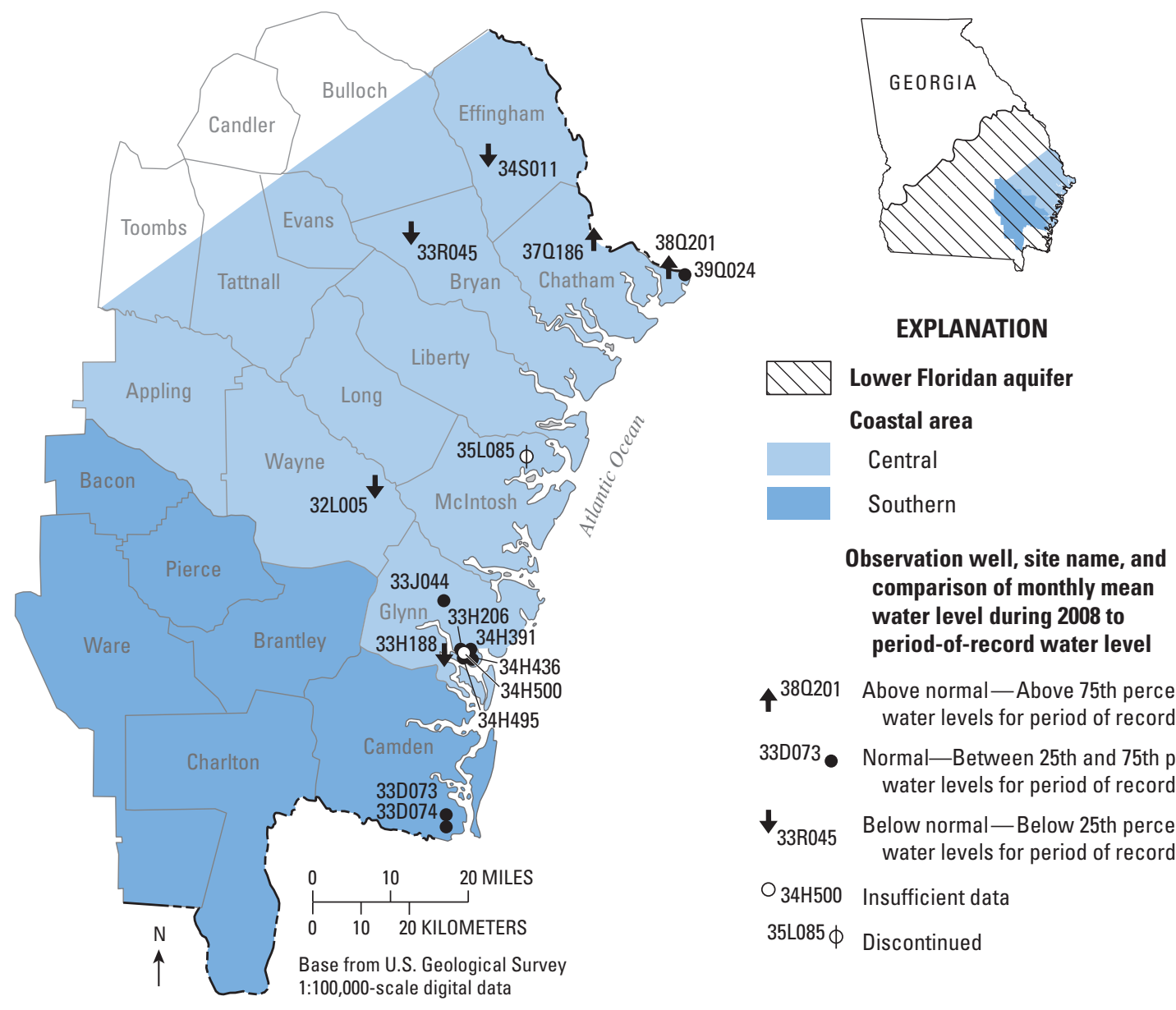

$\boldsymbol{\uparrow}^{380201}$ Above normal-Above 75th percentile

33D073 Normal-Between 25th and 75th percentile water levels for period of record

$\downarrow_{33 \text { R045 Below normal-Below 25th percentile }}$ water levels for period of record

$\mathrm{O}_{34 \mathrm{H} 500}$ Insufficient data

35L085 $\varnothing$ Discontinued

\begin{tabular}{|c|c|c|c|}
\hline Site name & Water-bearing unit ${ }^{1}$ & County & Other identifier ${ }^{2}$ \\
\hline $33 R 045$ & $\mathrm{LF}$ & Bryan & Coastal Sound Science Initiative test well \\
\hline 33D073 & LF & Camden & St Marys, test well (deep) \\
\hline 33D074 & $\mathrm{LF}$ & Camden & Coastal Sound Science Initiative, St Marys test well 2 \\
\hline 370186 & $P$ & Chatham & Hutchinson Island, test well 2 \\
\hline 380201 & $P$ & Chatham & Georgia Geologic Survey, Fort Pulaski, test well \\
\hline 390024 & LF & Chatham & Georgia Geologic Survey, Tybee Island, test well 1 \\
\hline $34 S 011$ & LF & Effingham & Coastal Sound Science Initiative, Pineora Ball Park test well \\
\hline $33 \mathrm{H} 188$ & $\mathrm{~F}$ & Glynn & U.S. Geological Survey, test well 26 \\
\hline $33 \mathrm{H} 206$ & LF & Glynn & Georgia-Pacific, south, test well 1 \\
\hline 33J044 & $\mathrm{LF}$ & Glynn & U.S. Geological Survey, test well 27 \\
\hline $34 \mathrm{H} 391$ & $\mathrm{LF}$ & Glynn & U.S. Geological Survey, test well 16 \\
\hline $34 \mathrm{H} 436$ & LF & Glynn & Georgia Geologic Survey, Coffin Park, test well 1 \\
\hline $34 \mathrm{H} 495$ & $\mathrm{~F}$ & Glynn & U.S. Geological Survey, test well 29 \\
\hline $34 \mathrm{H} 500$ & $\mathrm{LF}$ & Glynn & U.S. Geological Survey, test well 30 \\
\hline 35L085 & LF & Mclntosh & Hawthorne, test well 1 \\
\hline 32L005 & LF & Wayne & Hopkins No. 2 \\
\hline
\end{tabular}

Figure 24. Groundwater levels in the Lower Floridan aquifer in the central and southern coastal areas, Georgia, 2008. 
Lower Floridan aquifer

310810081323501

Glynn County

Well Depth: 2,720 feet Datum: 9.37 feet NGVD 29 Well Diameter: 10.00 inches
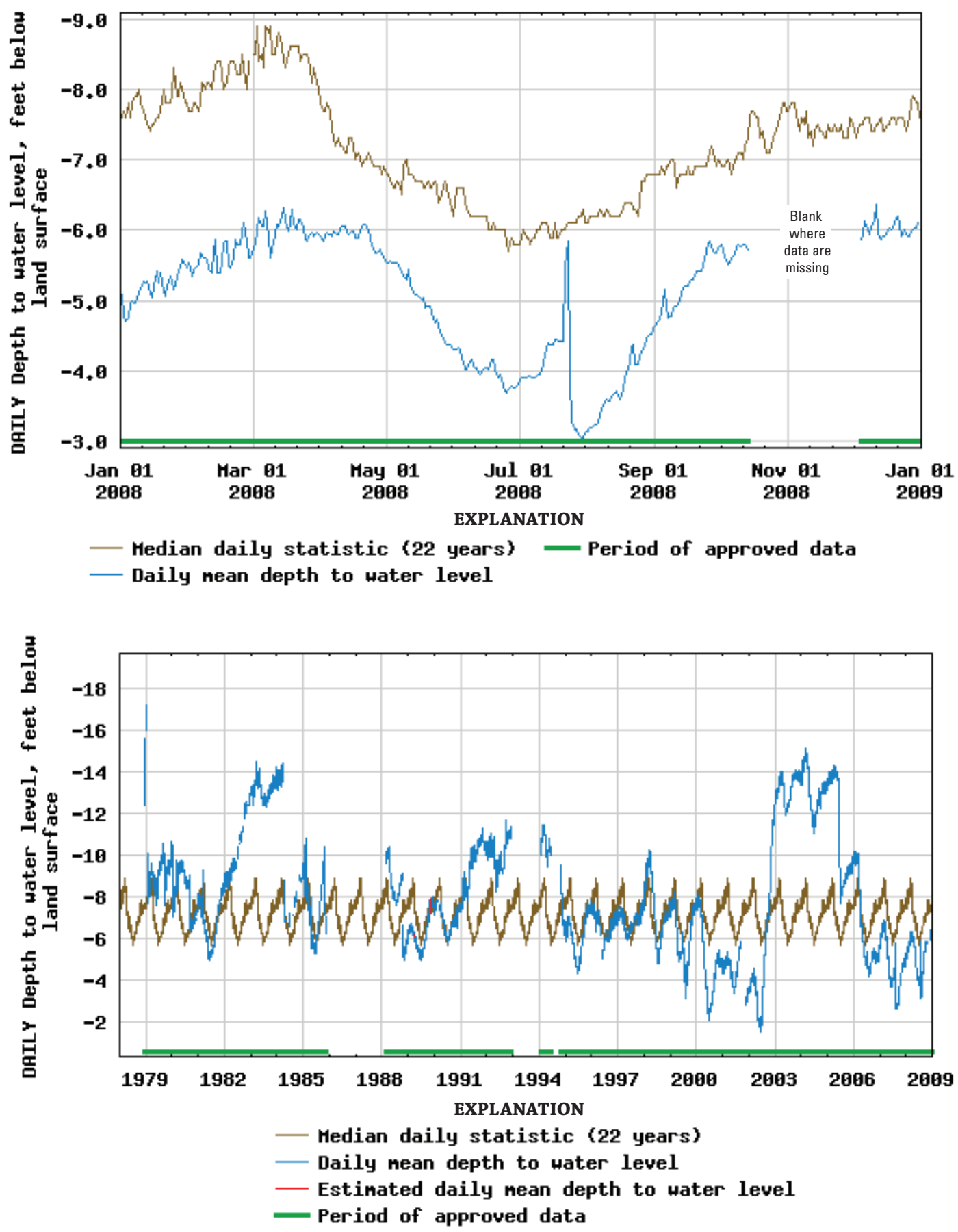

Figure 25. Periodic and daily mean water levels in well 33H188, Lower Floridan aquifer, Glynn County, Georgia, 1978-2008. 
Lower Floridan aquifer

310925081312201

Glynn County

Site Name: 33H206

Period of Record: 1983-2008

Well Depth: 1,100 feet Datum: 7.00 feet NGVD 29 Well Diameter: 10.00 inches
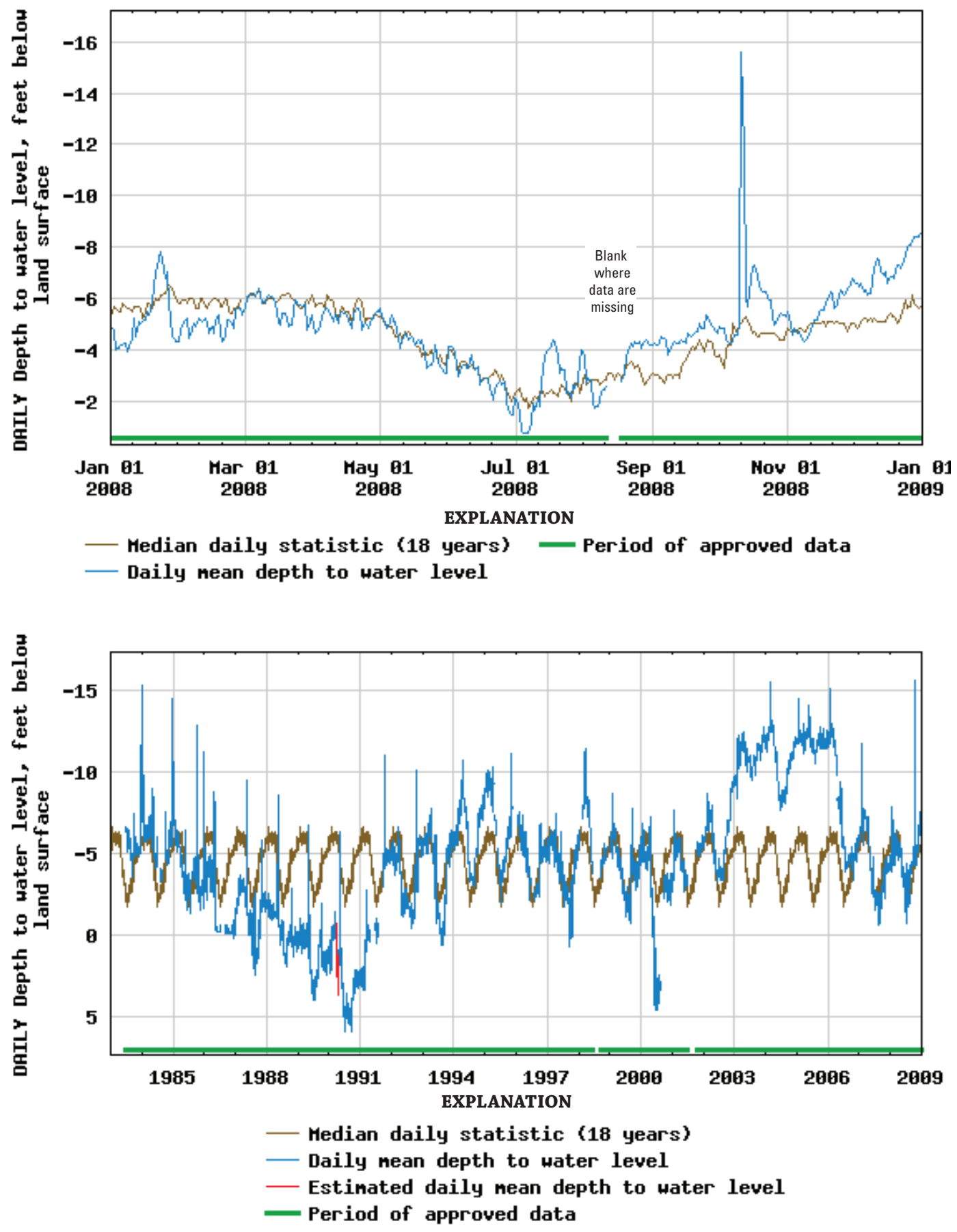

Figure 26. Periodic and daily mean water levels in well 33H206, Lower Floridan aquifer, Glynn County, Georgia, 1983-2008. 
Lower Floridan aquifer

311633081324001

Glynn County

Well Depth: 1,910 feet Datum: 20.0 feet NGVD 29 Well Diameter: 9.00 inches
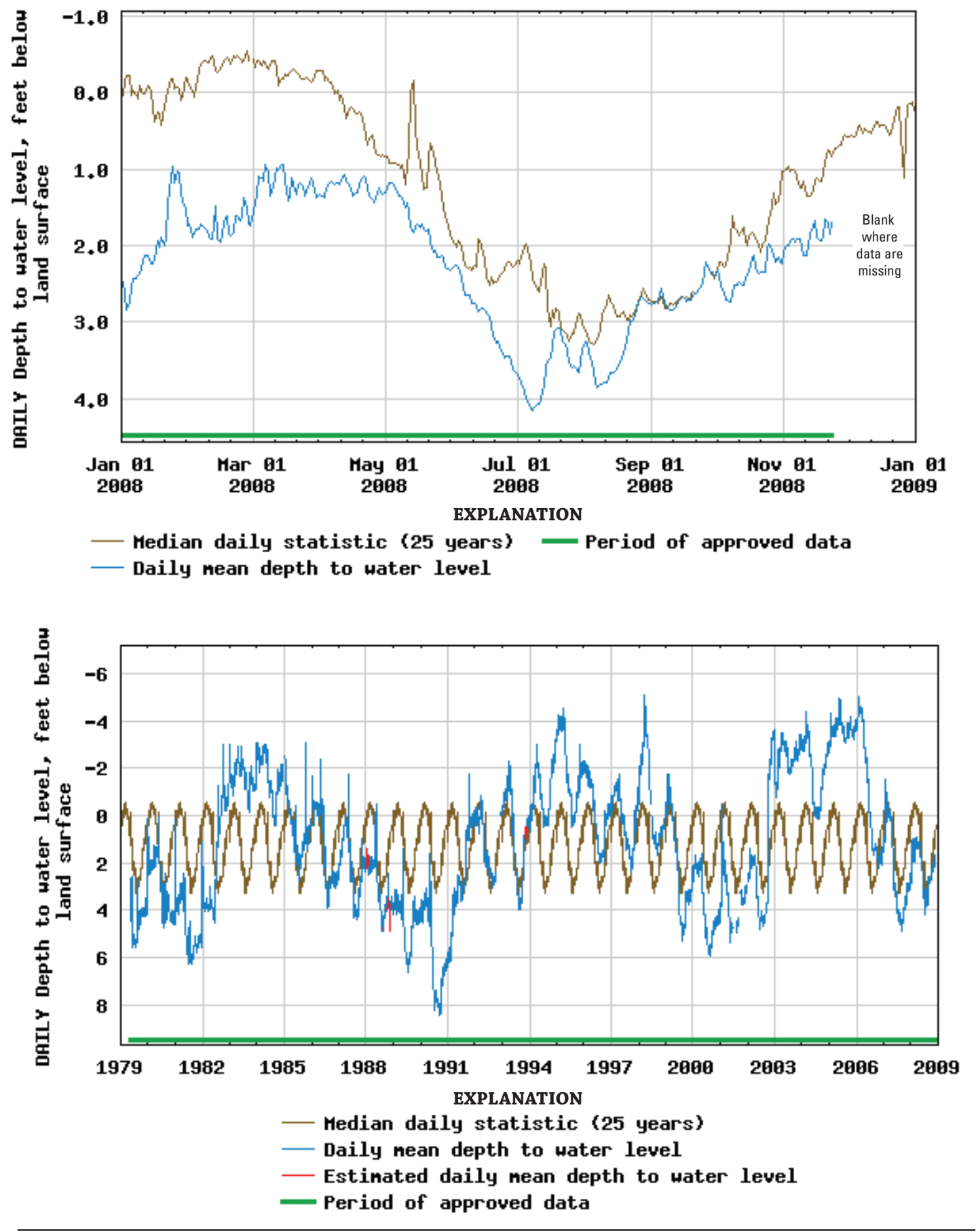

Figure 27. Periodic and daily mean water levels in well 33J044, Lower Floridan aquifer, Glynn County, Georgia, 1979-2008. 


\section{Lower Floridan aquifer}

310818081294201

Glynn County

Site Name: $34 \mathrm{H} 391$

Period of Record: 1975-2008

Well Depth: 1,158 feet Datum: 7.13 feet NGVD 29 Well Diameter: 4.00 inches
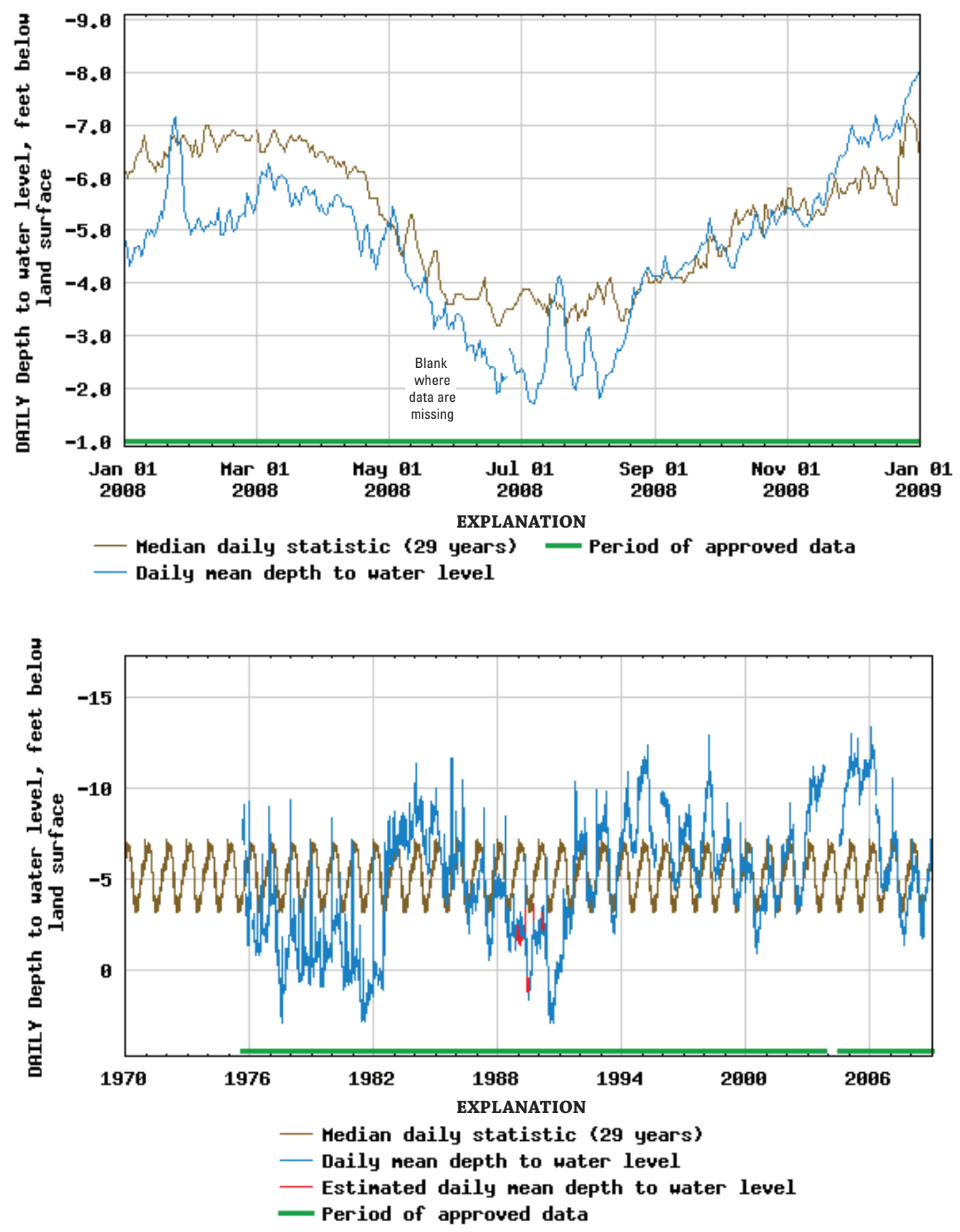

Figure 28. Periodic and daily mean water levels in well 34H391, Lower Floridan aquifer, Glynn County, Georgia, 1975-2008. 
Lower Floridan aquifer

310901081284401

Glynn County

Well Depth: 1,103 feet Datum: 6.62 feet NGVD 29 Well Diameter: 4.00 inches
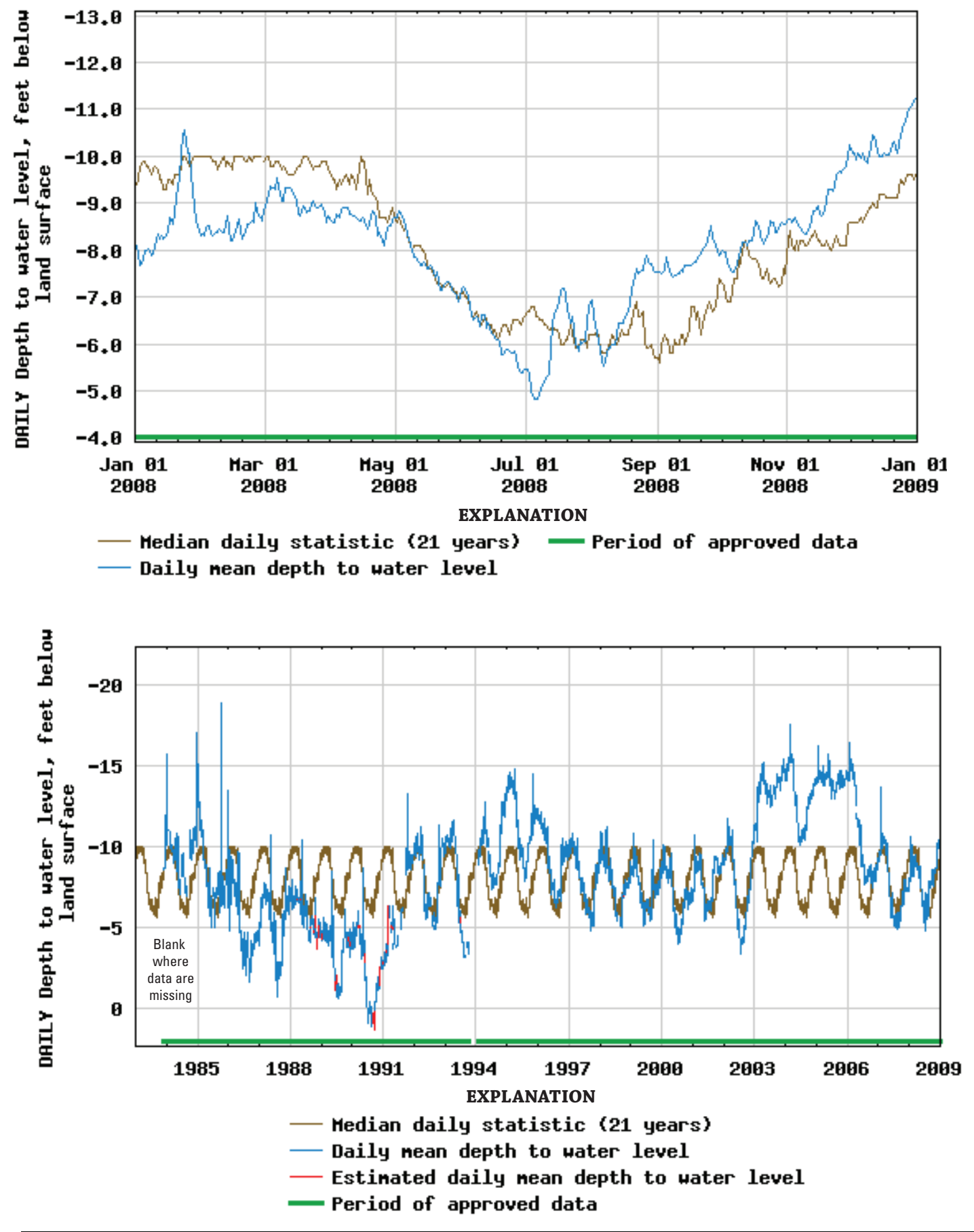

Figure 29. Periodic and daily mean water levels in well 34H436, Lower Floridan aquifer, Glynn County, Georgia, 1983-2008. 


\section{Lower Floridan aquifer}

310835081294501

Glynn County

Well Depth: 2720 feet Datum: 10 feet NGVD 29 Well Diameter: 8.00 inches
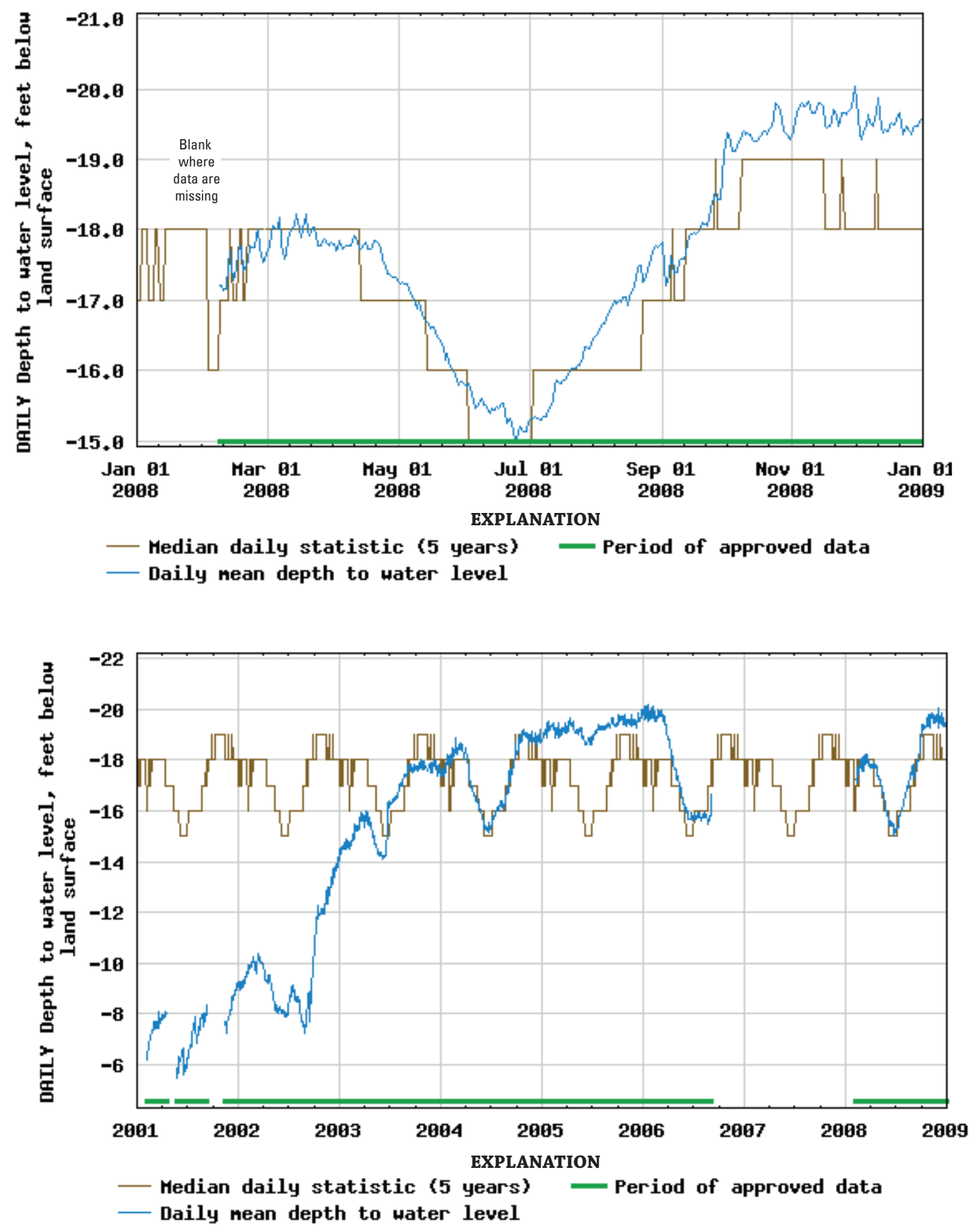

Figure 30. Periodic and daily mean water levels in well 34H495, Lower Floridan aquifer, Glynn County, Georgia, 2001-2008. 
Lower Floridan aquifer

310835081294502

Glynn County

Well Depth: 1,400 feet Datum: 10 feet NGVD 29 Well Diameter: 8.0 inches
Site Name: 34H500

Period of Record: 2001-2008
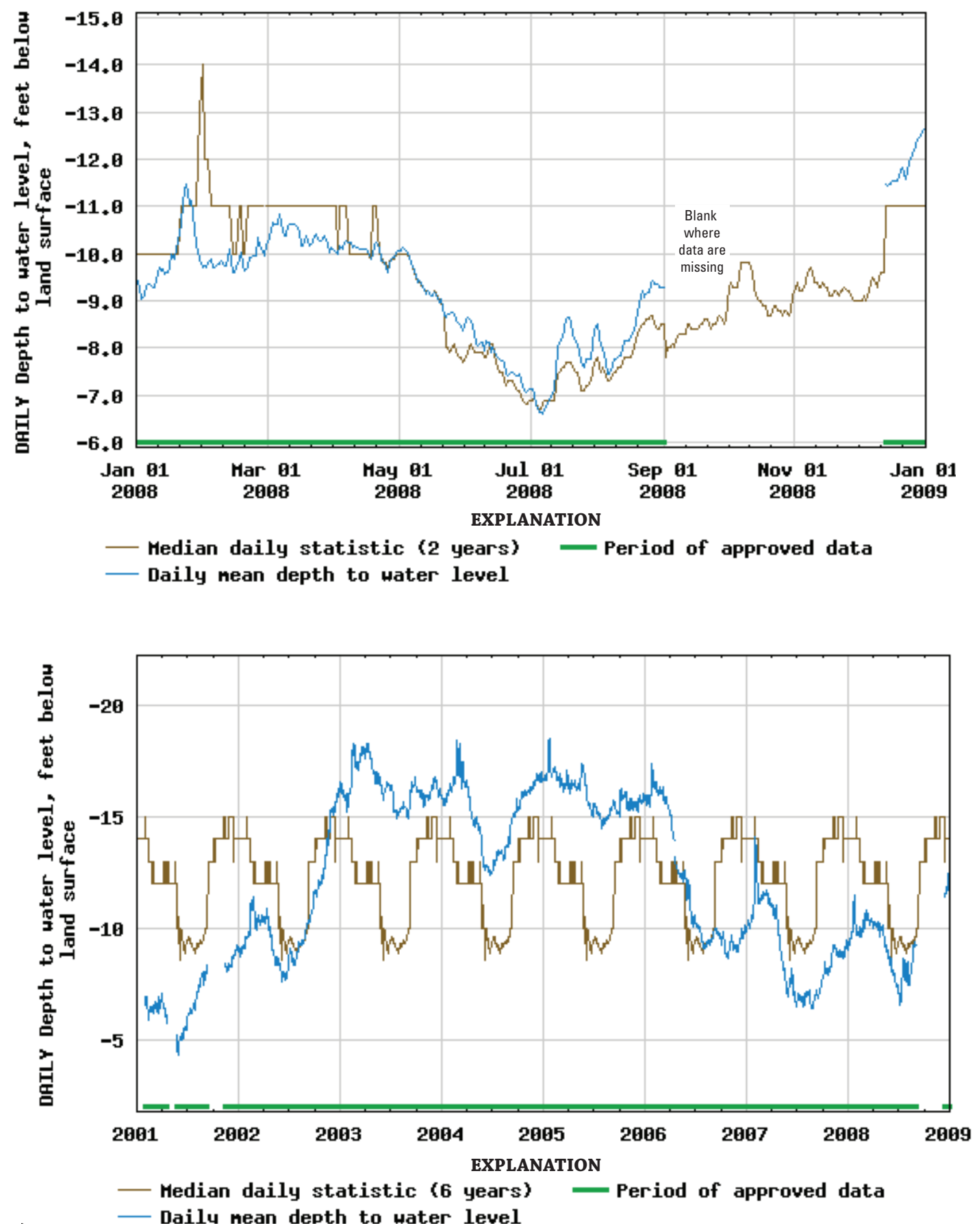

Figure 31. Periodic and daily mean water levels in well 34H500, Lower Floridan aquifer, Glynn County, Georgia, 2001-2008. 


\section{Chloride Concentrations}

Chloride concentrations have been monitored in the Brunswick area since the late 1950s when saltwater was first detected in wells completed in the Upper Floridan aquifer in the southernmost part of Brunswick (Wait, 1965). Saltwater has migrated upward from deep saline zones through breaches in confining units as a result of reduced pressure in water-bearing zones of the Upper Floridan aquifer. By the 1960s, chloride-contaminated groundwater had migrated northward toward two major industrial pumping centers. Currently (2009), the USGS collects and analyzes samples from a network of wells on an annual basis as part of the CWP (fig. 32; table 2).

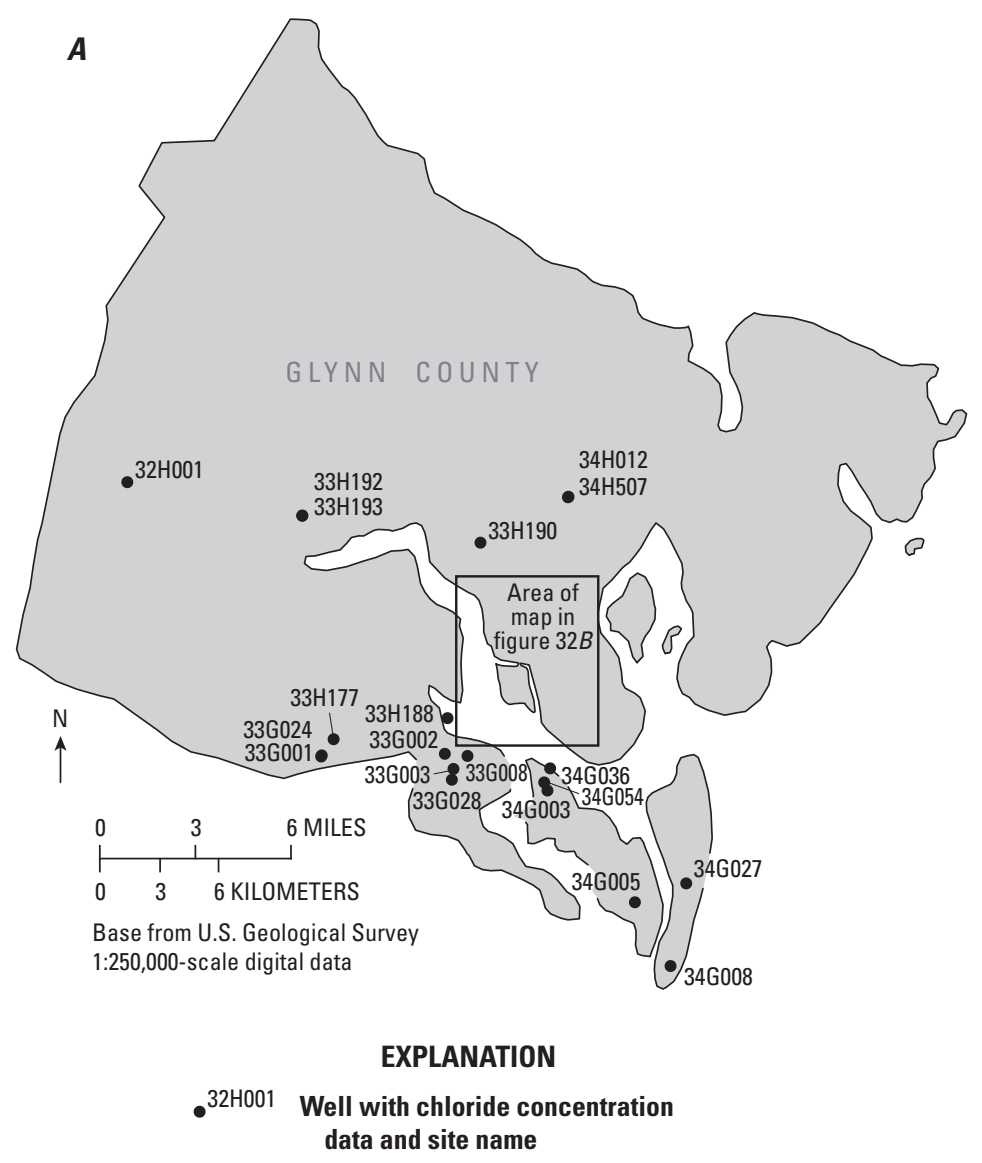

Figure 32. Chloride-monitoring network for the Brunswick-Glynn County area, Georgia: $(A)$ location and $(B)$ enlarged area. 


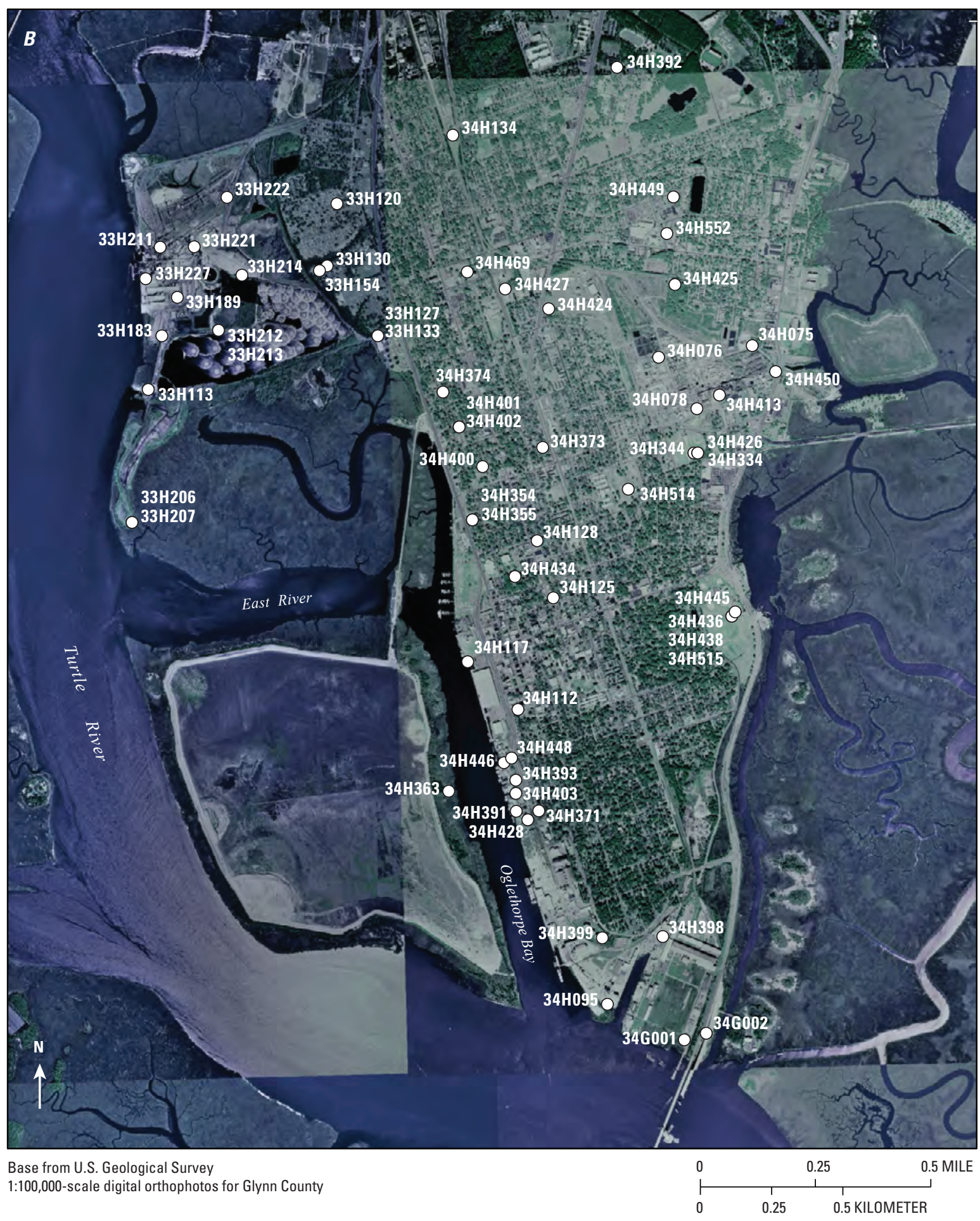

Explanation

34G002 Well with chloride concentration data and site name

Figure 32. Chloride-monitoring network for the Brunswick-Glynn County area, Georgia: $(A)$ location and $(B)$ enlarged area.-Continued 
Table 2. Chloride concentrations and specific conductance in water samples collected from wells in the Brunswick-Glynn County area, Georgia, July and August 2007 (chloride only) and July 2008.

[well locations shown in figs. $34 A$ and 34B; aquifer or system: S-Surficial, BAS-Brunswick aquifer system, LBA-lower Brunswick aquifer, UFA-Upper Floridan aquifer, FAS-Floridan aquifer system, LFA-Lower Floridan aquifer; $\mu \mathrm{S} / \mathrm{cm}$, microsiemens per centimeter; -, no data]

\begin{tabular}{|c|c|c|c|c|c|c|}
\hline \multirow{2}{*}{$\begin{array}{c}\text { Well } \\
\text { identification }\end{array}$} & \multirow{2}{*}{$\begin{array}{l}\text { Aquifer } \\
\text { or } \\
\text { system }\end{array}$} & \multirow[b]{2}{*}{ Subunit } & \multirow{2}{*}{$\begin{array}{c}\begin{array}{c}\text { July and } \\
\text { August } 2007\end{array} \\
\begin{array}{c}\text { Chloride, } \\
\text { in milligrams } \\
\text { per liter }\end{array}\end{array}$} & \multicolumn{3}{|c|}{ July 2008} \\
\hline & & & & $\begin{array}{c}\text { Chloride, } \\
\text { in milligrams } \\
\text { per liter }\end{array}$ & $\begin{array}{l}\text { Change in } \\
\text { chloride concen- } \\
\text { tration from } 2007\end{array}$ & $\begin{array}{c}\text { Specific } \\
\text { conductance, } \\
\text { in } \mu \mathrm{S} / \mathrm{cm}\end{array}$ \\
\hline $34 \mathrm{H} 428$ & $\mathrm{~S}$ & None & 13.3 & 13.5 & 0.2 & 481 \\
\hline $34 \mathrm{H} 515 *$ & $\mathrm{~S}$ & None & 5,250 & 5,450 & 200 & - \\
\hline $33 \mathrm{G} 002$ & UFA & Upper water-bearing zone & 73.4 & 76.3 & 2.9 & 737 \\
\hline 33G008 & UFA & Upper water-bearing zone & 30.0 & 32.7 & 2.7 & 504 \\
\hline $33 \mathrm{G} 024$ & UFA & Upper water-bearing zone & 17.7 & 18.2 & 0.5 & 466 \\
\hline 34G002 & UFA & Upper water-bearing zone & 72.1 & 79.8 & 7.7 & 713 \\
\hline $34 \mathrm{G} 054$ & UFA & Upper water-bearing zone & 44.5 & 45.3 & 0.8 & 580 \\
\hline $32 \mathrm{H} 001$ & BAS & None & 27.9 & 28.5 & 0.6 & 466 \\
\hline $33 \mathrm{H} 120$ & UFA & Upper water-bearing zone & 22.5 & 25.4 & 2.9 & 489 \\
\hline $33 \mathrm{H} 130$ & UFA & Upper water-bearing zone & 2,540 & 2,480 & -60 & 9,000 \\
\hline $33 \mathrm{H} 133$ & UFA & Upper water-bearing zone & 2,180 & 2,080 & -100 & 7,770 \\
\hline $33 \mathrm{H} 177$ & UFA & Upper water-bearing zone & 25.0 & 24.3 & -0.7 & 549 \\
\hline $33 \mathrm{H} 183$ & UFA & Upper water-bearing zone & - & 23.8 & - & - \\
\hline $33 \mathrm{H} 190$ & UFA & Upper water-bearing zone & 22.5 & 22.3 & -0.2 & 462 \\
\hline $33 \mathrm{H} 193$ & UFA & Upper water-bearing zone & 18.0 & 18.6 & 1 & 433 \\
\hline $34 \mathrm{H} 112$ & UFA & Upper water-bearing zone & 1,450 & 1,430 & -20 & 5,300 \\
\hline $34 \mathrm{H} 117$ & UFA & Upper water-bearing zone & 551 & 545 & -6.0 & 2,380 \\
\hline $34 \mathrm{H} 125$ & UFA & Upper water-bearing zone & 360 & 321 & -39 & 1,660 \\
\hline $34 \mathrm{H} 334$ & UFA & Lower water-bearing zone & 1,090 & 1,070 & -20.0 & 4,240 \\
\hline $34 \mathrm{H} 344$ & UFA & Upper water-bearing zone & 30.0 & 26.2 & -3.8 & 480 \\
\hline $34 \mathrm{H} 355$ & UFA & Upper water-bearing zone & 326 & 341 & 15 & 1,620 \\
\hline $34 \mathrm{H} 363$ & UFA & Upper water-bearing zone & 80.9 & - & - & - \\
\hline $34 \mathrm{H} 371$ & UFA & Upper water-bearing zone & 15.2 & 15.4 & 0.2 & 451 \\
\hline $34 \mathrm{H} 373$ & UFA & Upper water-bearing zone & 353 & 349 & -4.0 & 1,770 \\
\hline $34 \mathrm{H} 374$ & UFA & Upper water-bearing zone & 981 & 995 & 14 & 4,110 \\
\hline $34 \mathrm{H} 392$ & UFA & Upper water-bearing zone & 18.7 & 19.2 & 0.5 & 422 \\
\hline $34 \mathrm{H} 393$ & UFA & Upper water-bearing zone & 1,870 & 1,880 & 10 & 6,820 \\
\hline $34 \mathrm{H} 400$ & UFA & Upper water-bearing zone & 433 & 422 & -11 & 1,970 \\
\hline
\end{tabular}


Table 2. Chloride concentrations and specific conductance in water samples collected from wells in the Brunswick-Glynn County area, Georgia, July and August 2007 (chloride only) and July 2008.-Continued

[well locations shown in figs. $34 A$ and 34B; aquifer or system: S-Surficial, BAS-Brunswick aquifer system, LBA-lower Brunswick aquifer, UFA-Upper Floridan aquifer, FAS-Floridan aquifer system, LFA-Lower Floridan aquifer; $\mu \mathrm{S} / \mathrm{cm}$, microsiemens per centimeter; - , no data]

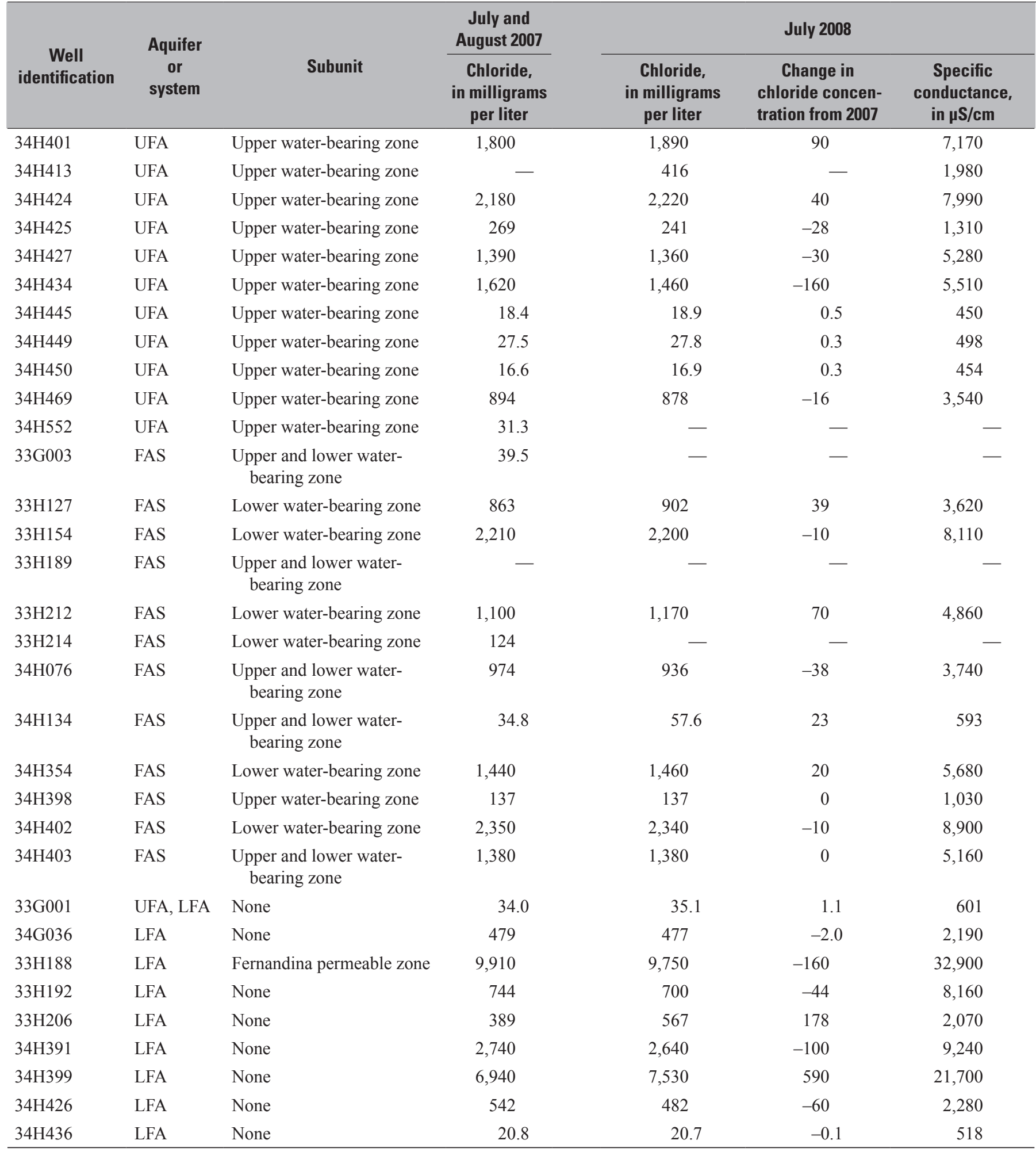

*Replaced well 34H438 


\section{Upper Floridan Aquifer}

The area of chloride contamination in the Upper Floridan aquifer at Brunswick during July 2008 was mapped based on samples from 26 wells (fig. 33). During this period, the chloride concentration was greater than $250 \mathrm{mg} / \mathrm{L}$, the State and Federal secondary drinking-water standard (Georgia Environmental Protection Division, 1997; U.S. Environmental Protection Agency, 2000), in an approximate 2- $\mathrm{mi}^{2}$ area and exceeded $2,250 \mathrm{mg} / \mathrm{L}$ in part of the area. Yearly fluctuations of chloride concentration indicate increases as much as $90 \mathrm{mg} / \mathrm{L}$ and decreases as much as $100 \mathrm{mg} / \mathrm{L}$ from 2007 to 2008 (fig. 34; table 2). The July 2008 map (fig. 33) is similar to previously published maps for 2007 (Cherry and Clarke, 2008) and shows that areas of highest concentration are near the two industrial pumping centers in the northern part of the city of Brunswick, as well as the original area of contamination in the southern part of the city.

Graphs of chloride concentrations in water samples from wells with open intervals in the upper and lower waterbearing zones of the Upper Floridan aquifer are shown for the southern Brunswick area (34H393 and 34H403, fig. 35) and northern Brunswick area (33H133 and 33H127, fig. 36). Chloride concentration in water from the Lower Floridan aquifer is shown for well 34H391 in the southern Brunswick area (fig. 35). Additional information about water-quality monitoring in the Brunswick area can be accessed at http://ga.water.usgs.gov/projects/brunswick/.

During July 2008, chloride concentrations in the Brunswick area generally were lower than in 2007, with decreases as much as $100 \mathrm{mg} / \mathrm{L}$ in the northwestern part of the area (fig. 34). Chloride concentrations in the southern Brunswick area continued to decrease in well 34H393 and 34H391 and remained about the same in well 34H403 since 2007 (fig. 35). In the northern Brunswick area, chloride concentrations have increased since the 1960s, reflecting influences of local pumping (fig. 36). During 2007-2008, chloride concentrations decreased in well $33 \mathrm{H} 133$ and increased slightly in well 33H127 (fig. 36; table 2).

Outside the plume area, chloride concentrations are less than the $250 \mathrm{mg} / \mathrm{L}$ drinking-water standard (fig. 33; table 2). However, local areas have chloride concentrations greater than $50 \mathrm{mg} / \mathrm{L}$, which is considered to be greater than background levels, and includes concentrations in wells $34 \mathrm{G} 002$ and 34H398 (fig. 32; table 2). The reason for elevated chloride concentrations in these wells remains unclear, but elevated concentrations could be related to failed or improper wellcasing seals (Hall and Peck, 2005). 

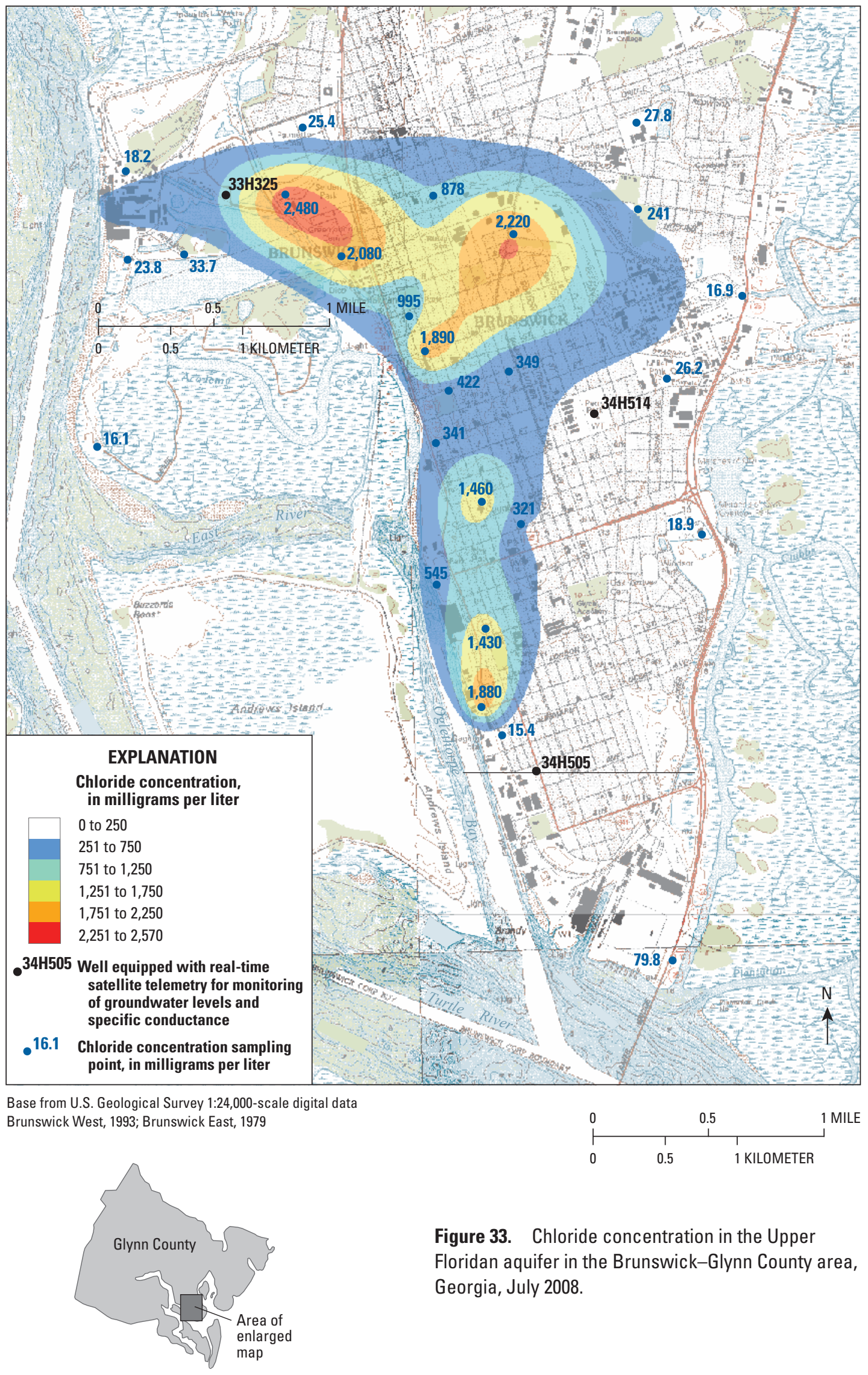

Figure 33. Chloride concentration in the Upper Floridan aquifer in the Brunswick-Glynn County area, Georgia, July 2008. 

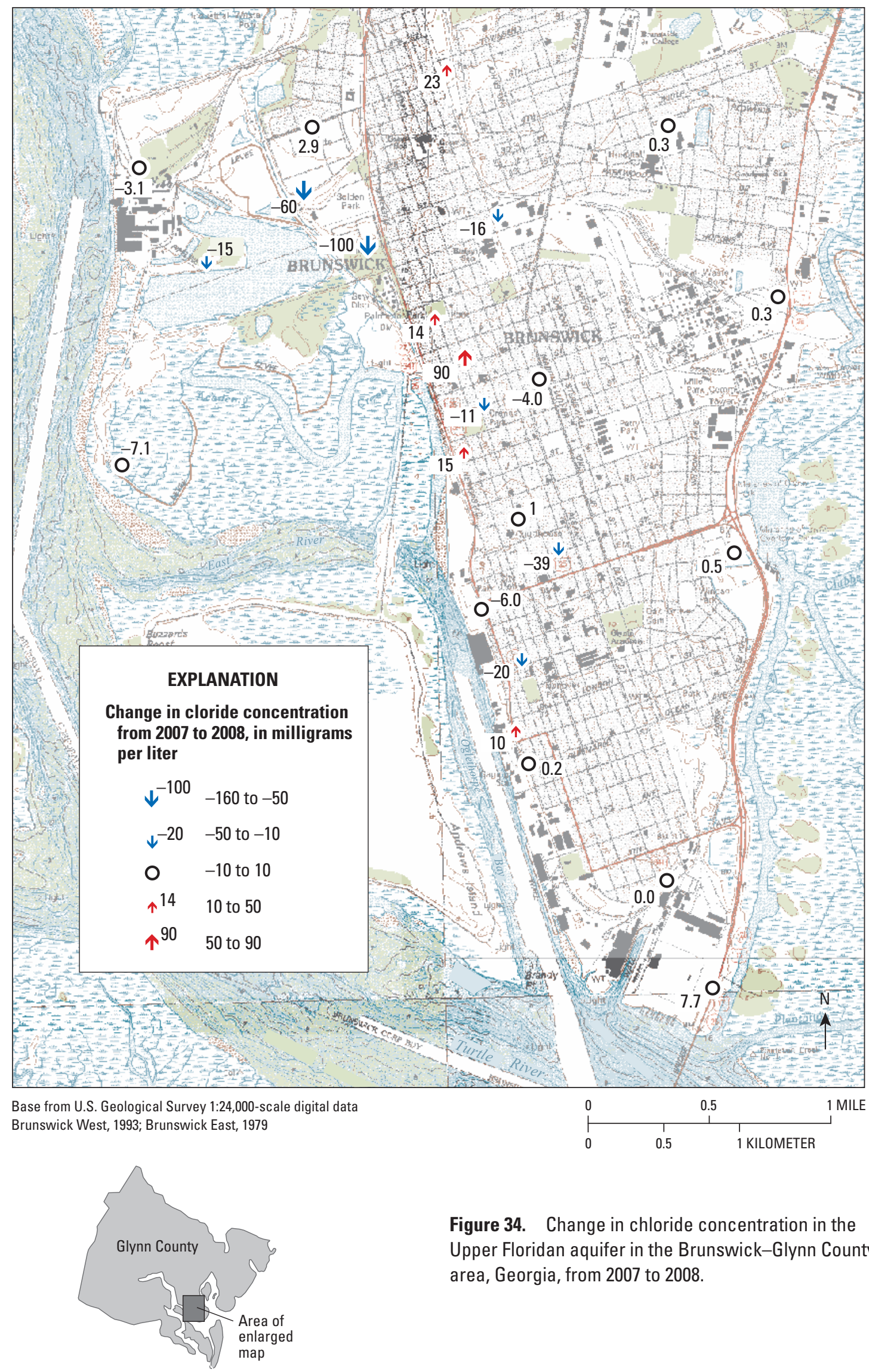

Figure 34. Change in chloride concentration in the Upper Floridan aquifer in the Brunswick-Glynn County area, Georgia, from 2007 to 2008. 


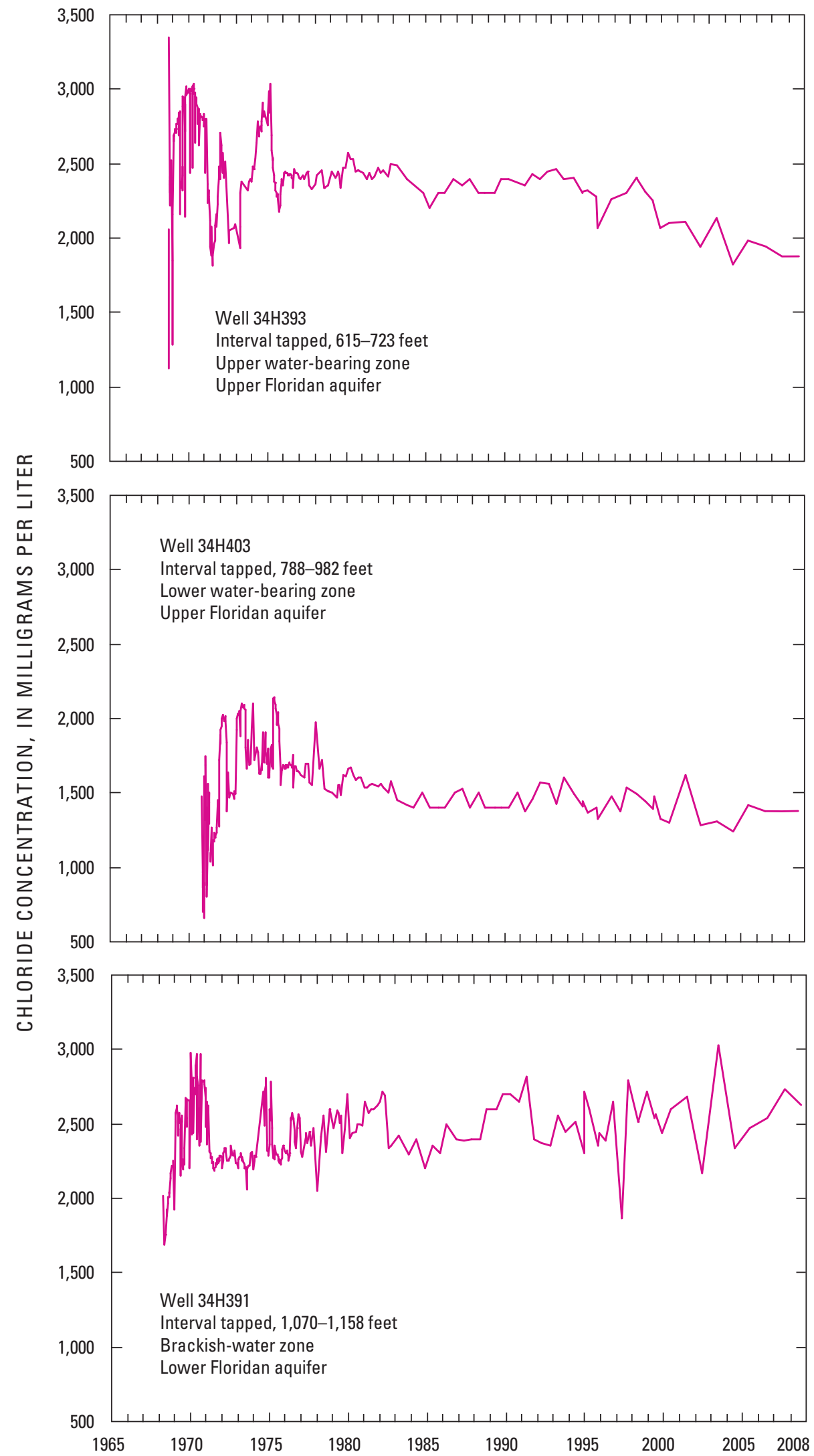

Figure 35. Chloride concentration in water for selected wells in the southern Brunswick-Glynn County area, Georgia, 1968-2008 (see figure 32B for well location). 


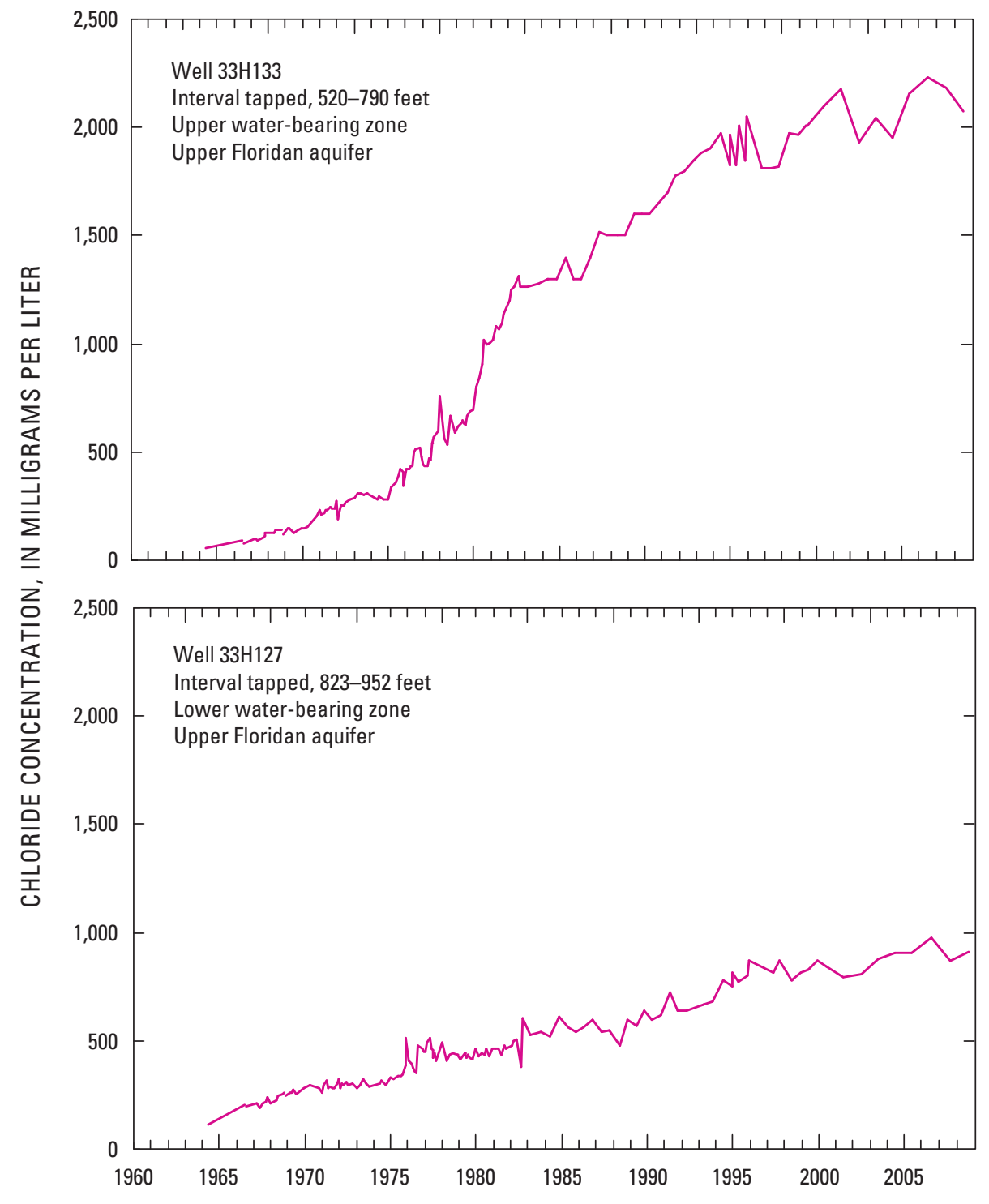

Figure 36. Chloride concentration in water for selected wells in the northern Brunswick-Glynn County area, Georgia, 1968-2008 (see figure 32B for well location). 


\section{Real-Time Monitoring of Specific Conductance and Water Levels}

To monitor the extent of chloride contamination in the Brunswick area, a network of real-time monitoring wells completed in the upper and lower water-bearing zones of the Upper Floridan aquifer was established around the plume (figs. 17, 33). This network includes the Perry Park site (well 34H514) funded by the CWP and the Southside Baptist Church (wells 34H504 and 34H505) and Georgia-Pacific Cellulose (wells 33H324 and 33H325) sites funded by GaEPD (fig. 17). During 2007, each of the five sites was equipped with real-time water-level recorders, and the Perry Park site (well 34H514) was also equipped with a realtime specific conductance monitor. The Southside Baptist Church site (well 34H505) and Georgia-Pacific Cellulose site $(33 \mathrm{H} 325)$ were instrumented for real-time specific conductance monitoring during 2008 (fig. 33). Measurement depths in each well were determined using borehole resistivity and temperature logs to delineate water-bearing zones vulnerable to saltwater contamination (Walls and others, 2009). This equipment measures specific conductance, a surrogate for chloride concentration, to monitor the potential movement of saltwater into groundwater of the Upper Floridan aquifer.

The Perry Park well (34H514), which is immediately outside the plume area, had chloride concentrations that fluctuated in response to pumping changes (fig. 37). The specific conductance at this site during 2007-2008 fluctuated from 423 to 930 microsiemens per centimeter $(\mu \mathrm{S} / \mathrm{cm})$. A correlation between chloride concentration and specific conductance indicates this range in values corresponds to chloride levels that are generally less than $100 \mathrm{mg} / \mathrm{L}$ (fig. 38; table 2).
Water levels in the Georgia-Pacific Cellulose wells (33H324 and 33H325) indicate the gradient is downward from the upper into the lower water-bearing zone, the reverse of the naturally occurring gradient between these zones (fig. 39). The water levels in these wells are influenced by pumping because of their close proximity to the production wells at Georgia-Pacific Cellulose, which tap into the upper and the lower water-bearing zones of the Upper Floridan aquifer. Specific conductance at well 33H325 during 2008 fluctuated from 7,090 to $7,420 \mu \mathrm{S} / \mathrm{cm}$. Using the correlation chart between chloride concentration and specific conductance yields chloride concentrations ranging between 1,900 and 2,000 mg/L (fig. 38).

The Southside Baptist Church wells (34H504 and $34 \mathrm{H} 505$ ) are located outside the plume area and are not influenced by any local pumping in the area. The water levels in these wells indicate that the natural gradient is upward from the lower to the upper water-bearing zone of the Upper Floridan aquifer (fig. 40). The specific conductance at this site during 2008 increased from 973 to $1,940 \mu \mathrm{S} / \mathrm{cm}$, with a steady rise throughout the entire year. The increasing levels of specific conductance correspond to a period in which the head differentials between the upper and the lower waterbearing zones of the Upper Floridan aquifer are minimized and the gradient is decreased. Using the correlation chart between chloride concentration and specific conductance yields chloride levels ranging between 200 and $500 \mathrm{mg} / \mathrm{L}$ (fig. 38). The real-time data are available on the USGS Web site and can be accessed at http://waterdata.usgs.gov/ga/nwis/ current/?type $=g w$.

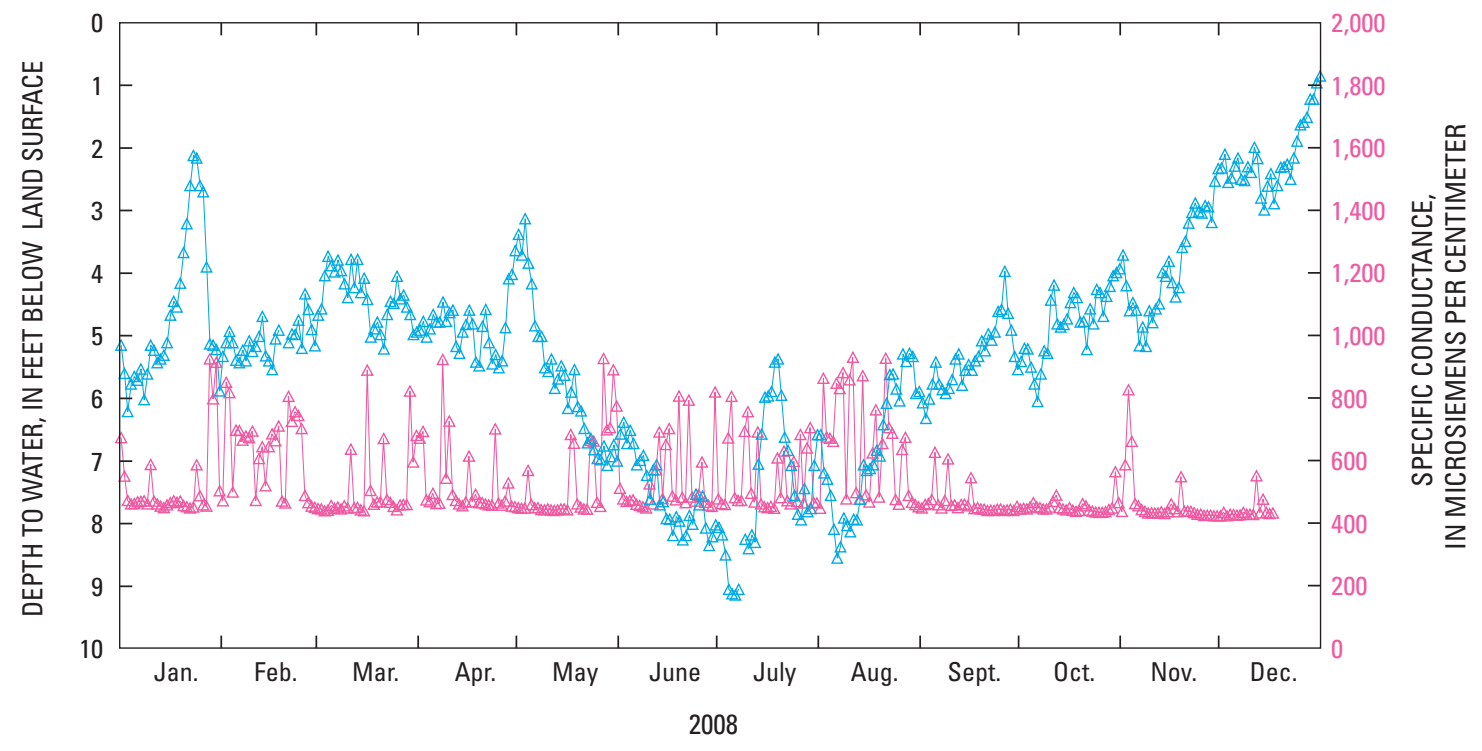

Figure 37. Daily mean groundwater levels and periodic specific conductance in the Upper Floridan aquifer at well 34H514, Perry Park, Brunswick-Glynn County area, Georgia, 2008. 

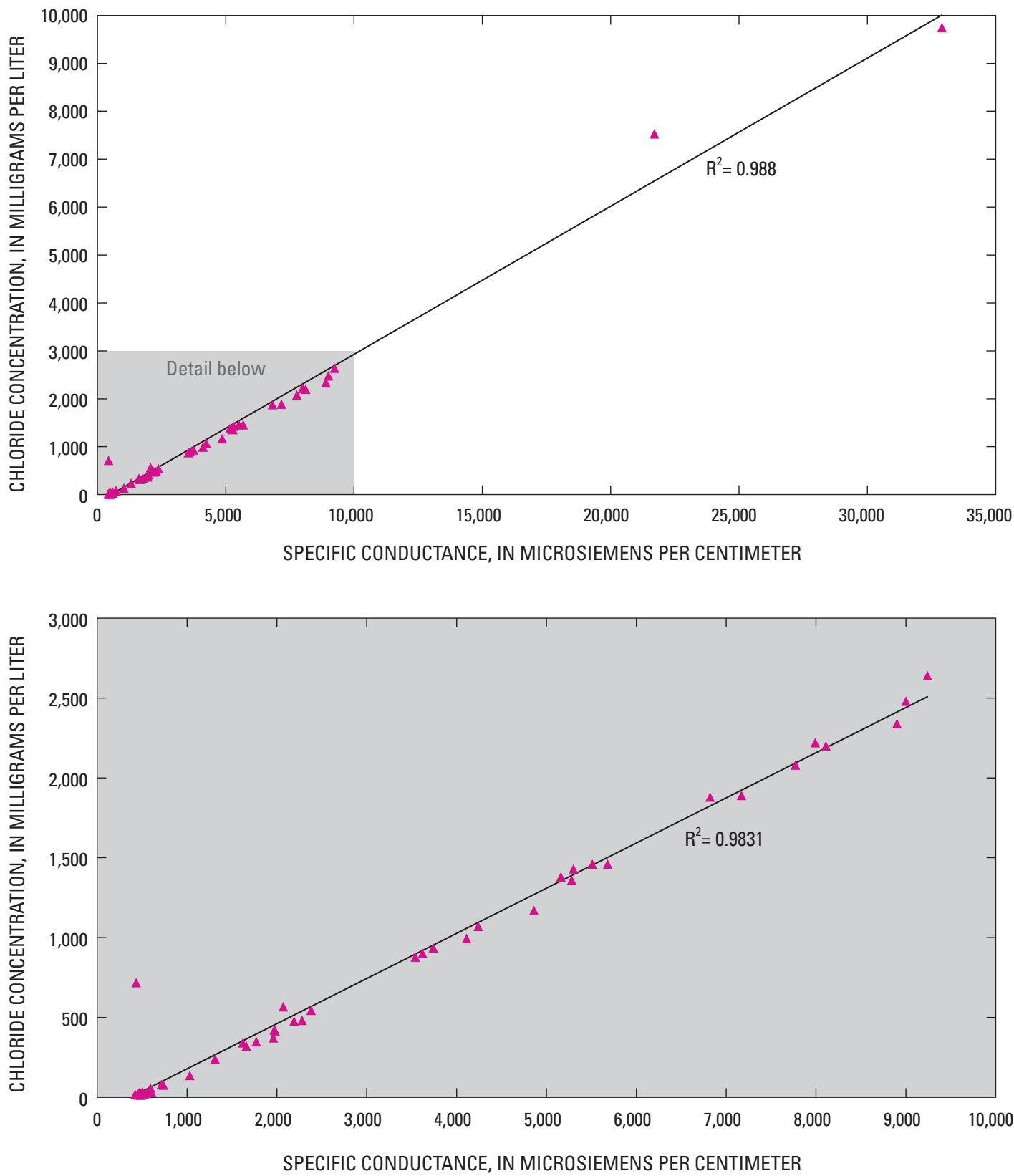

Figure 38. Correlation between chloride concentration and specific conductance from groundwater samples taken in the Brunswick-Glynn County area, Georgia, July 2008. 

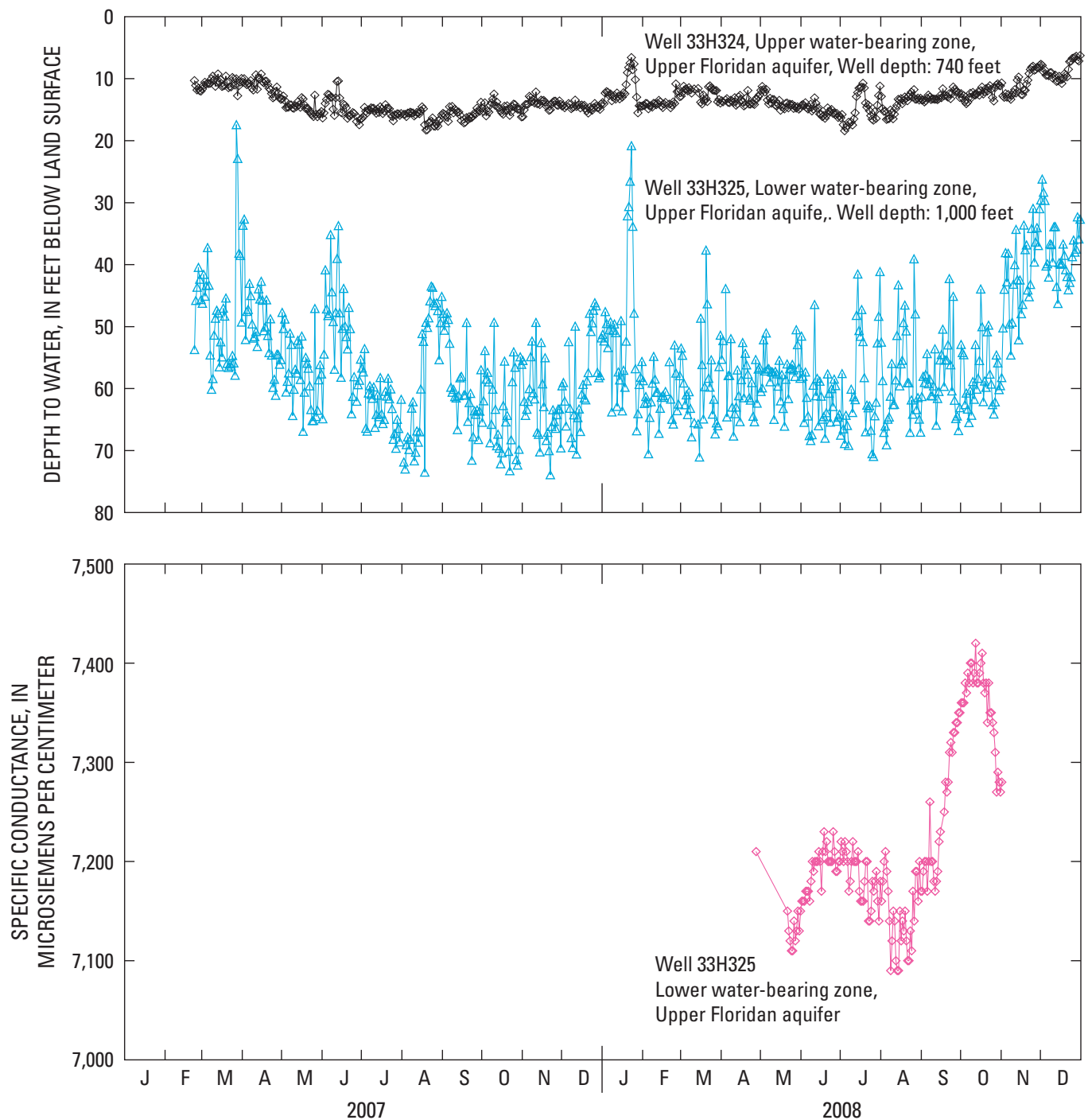

Figure 39. Daily mean water levels in wells $33 \mathrm{H} 324$ and $33 \mathrm{H} 325$, and specific conductance in well 33H325 Upper Floridan aquifer, Brunswick-Glynn County area, Georgia, 2008. 

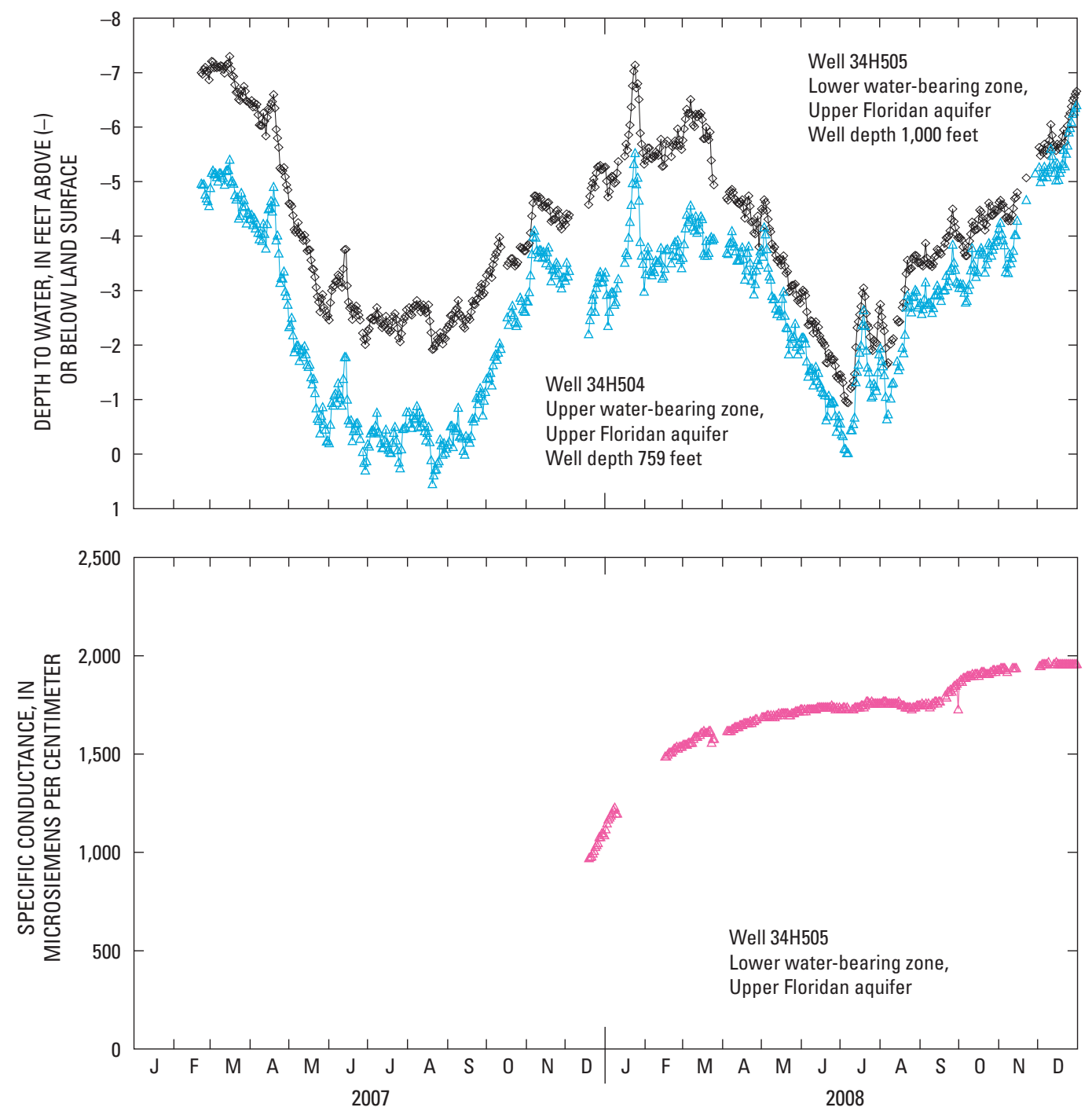

Figure 40. Daily mean groundwater levels and periodic specific conductance in the Upper Floridan aquifer at wells 34H504 and 34H505, Brunswick-Glynn County area, Georgia, 2008. 


\section{Surficial and Brunswick Aquifer Systems}

Historically, water-quality data-collection efforts in the Glynn County area have focused on the Floridan aquifer system. Clarke and others (1990), however, recognized that locally, water-quality problems exist in the surficial and Brunswick aquifer systems. These problems typically can be associated with (1) saltwater encroachment in shallow wells near the coast, tidal rivers, and estuaries; (2) upward leakage of water from underlying aquifers through semiconfining units or fractures as a result of natural or pumping-induced head gradients; or (3) failed well casings. Localized saltwater contamination has been recognized in a number of areas along the coast, including Vernonburg, GA, in Chatham County (Hall and Peck, 2005) and Sea Island, GA, in Glynn County (Julie Vann, Georgia Environmental Protection Division, written commun., July 2005).
During 2008, water samples were collected and analyzed for chloride concentration from two wells completed in the surficial aquifer-well 34H515 and well 34H428 (table 2). Well 34H515 was drilled in 2005 as a replacement well for well 34H438, which had shown a large increase in chloride concentration (fig. 41). The new well produced similar chloride concentrations, verifying the increase indicated by the previous well. The reason for the increase is unknown - no known supply wells are completed in the surficial aquifer in the area nor have there been any changes in land-use practices in the immediate area. The monitoring of chloride concentrations in this well is ongoing. The well is located in close proximity to a saltwater marsh and tidally influenced canals designed to prevent flooding during high tide. The only other well open to the surficial aquifer system (well 34H428) continues to show chloride levels below $20 \mathrm{mg} / \mathrm{L}$.

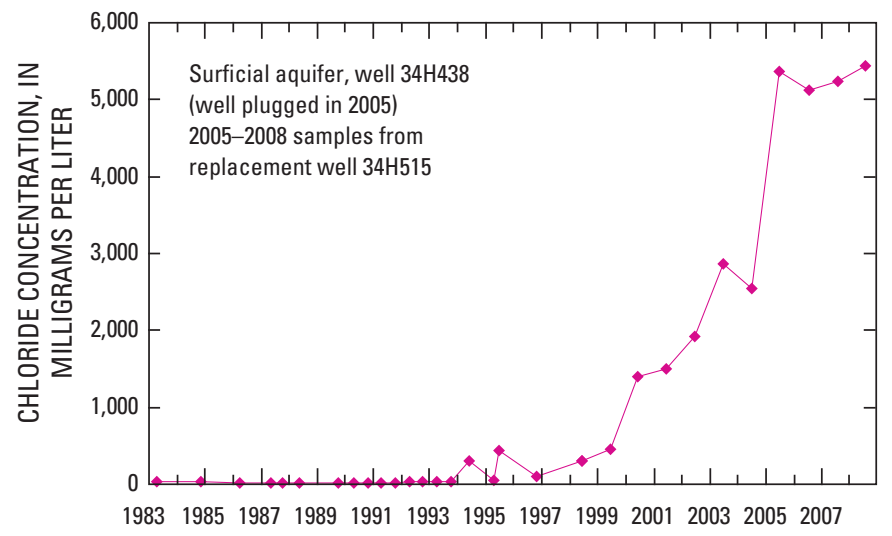

Figure 41. Chloride concentration in well $34 \mathrm{H} 438$ and replacement well $34 \mathrm{H} 515$, surficial aquifer system, in the Brunswick-Glynn County area, Georgia, 1983-2008 (see figure $32 B$ for well location). 


\section{Groundwater Studies}

The CWP provides for the ongoing collection of hydrologic data to support a better understanding of the occurrence and controls on saltwater contamination for the evaluation of alternative water sources. In past years, the program has included collecting borehole geophysical logs to characterize physical and chemical properties of hydrogeologic units and conducting field inventories of existing wells to obtain groundwater-level and water-quality data and improve data coverage in the area.

During 2008, the principal focus of groundwater studies for the CWP was the refinement of an existing groundwaterflow model to enable better-detailed simulations in the vicinity of the chloride plume. The model has been designed to evaluate changes in hydraulic gradients near the chloride plume resulting from changes in pumpage (Cherry and Payne, 2007). Currently (2009), the lateral extent of chloride contamination is contained because large groundwater withdrawals create a depression in the potentiometric surface of the Upper Floridan aquifer, and groundwater flows inward from surrounding areas along a hydraulic gradient. If this gradient were reversed because of large-scale pumping outside of the plume area, chloride contaminated groundwater could flow outward in the opposite direction and contaminate freshwater areas.

The model used in this study, described in detail in Payne and others (2005), uses MODFLOW-2000 (Harbaugh and others, 2000), which is a finite-difference, constant-density flow simulator. The model boundaries extend throughout the coastal Georgia area and into adjacent parts of Florida and South Carolina and encompass an area approximately $42,155 \mathrm{mi}^{2}$ (fig. 42). The original MODFLOW model was horizontally discretized using a variably spaced grid with cell sizes ranging from approximately $4,000 \times 5,000 \mathrm{ft}$ at Savannah and Brunswick to $16,500 \times 16,500 \mathrm{ft}$ near the lateral boundaries (Payne and others, 2005). Grid density is higher at Savannah and Brunswick, Georgia, to enable simulation of steeper head gradients near areas of concentrated pumping. Each unit is represented with one layer of grid cells in the vertical dimension. To enable an even more refined simulation of hydraulic gradients near the Brunswick chloride plume, the grid size for the refined model is reduced to $500 \mathrm{x} 500 \mathrm{ft}$.
The original model (Payne and others, 2005) is comprised of seven aquifers and confining units. These include, in descending order:

- the confined upper and lower water-bearing zones of the surficial aquifer system, grouped together (unit 1);

- the Brunswick aquifer system confining unit (unit 2);

- the upper and lower Brunswick aquifers, grouped as the Brunswick aquifer system (unit 3);

- the Upper Floridan confining unit (unit 4);

- the Upper Floridan aquifer (units 5);

- the Lower Floridan confining unit (unit 6); and

- the Lower Floridan aquifer (unit 7).

The refined model incorporates additional model layers to provide for local variations in hydraulic properties at Brunswick (fig. 43). This includes subdividing the Brunswick aquifer system (unit 3) into separate units for the upper and lower Brunswick aquifers and subdividing the Upper Floridan aquifer (unit 4) into upper and lower water-bearing zones as defined by Wait and Gregg (1974). Each new layer is separated from adjacent aquifers by a semiconfining unit. These changes were made in order to more accurately simulate the horizontal and vertical hydraulic gradients that have been documented for these units in the Brunswick-Glynn County area.

The original model (Payne and others, 2005) simulated steady-state conditions during predevelopment (pre-1900), 1980, and 2000. The refined model is being updated to include simulated conditions during 2004. Preliminary model results indicate that residuals between simulated and observed heads provide a reasonable match. Thus, the model can be used to evaluate a variety of groundwater management scenarios, and the resulting effect on the chloride plume and hydraulic gradients near the chloride plume (Cherry, 2009). The updated model is being used to evaluate potential effects of seven groundwater-management scenarios on hydraulic gradients near the chloride plume. 

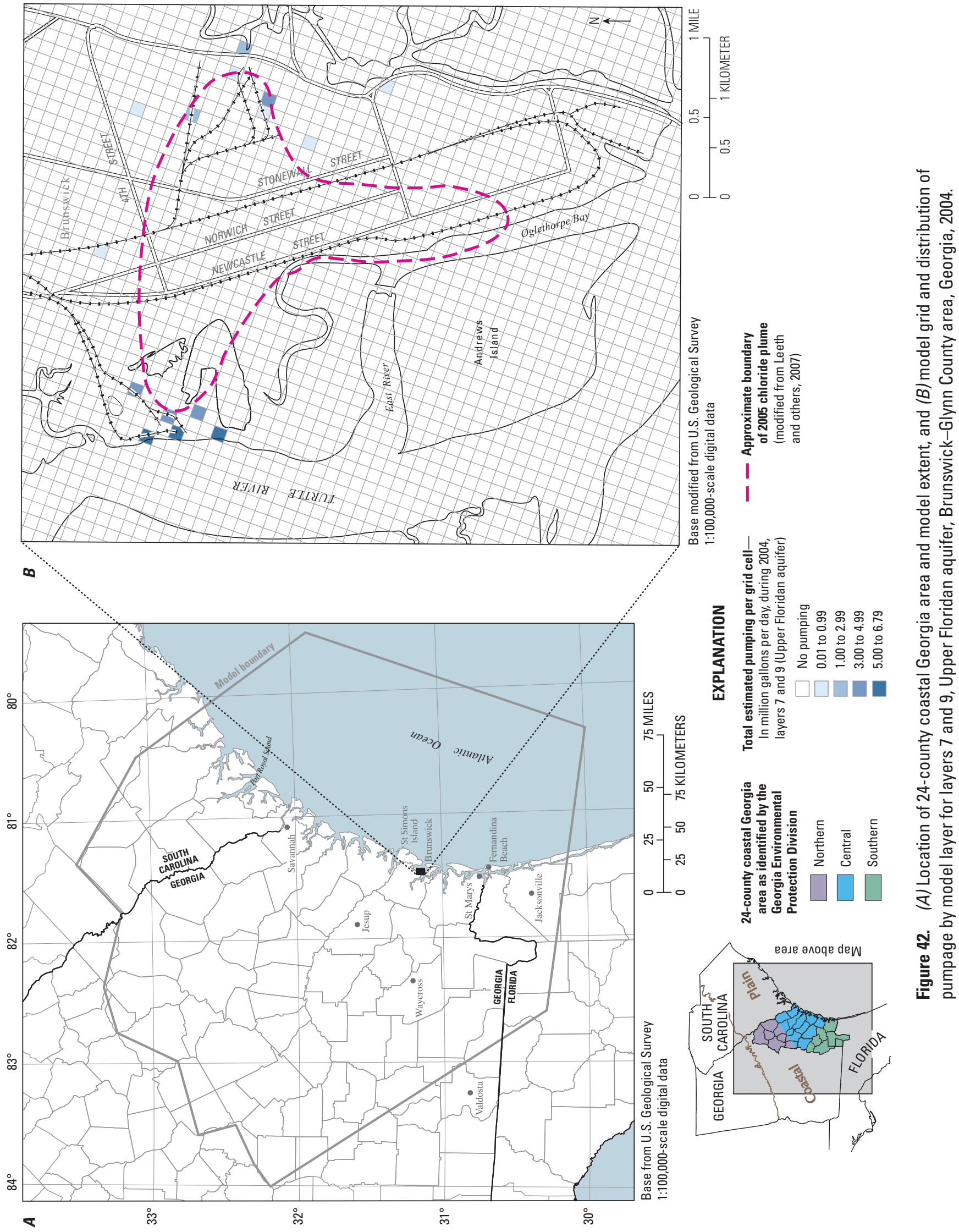


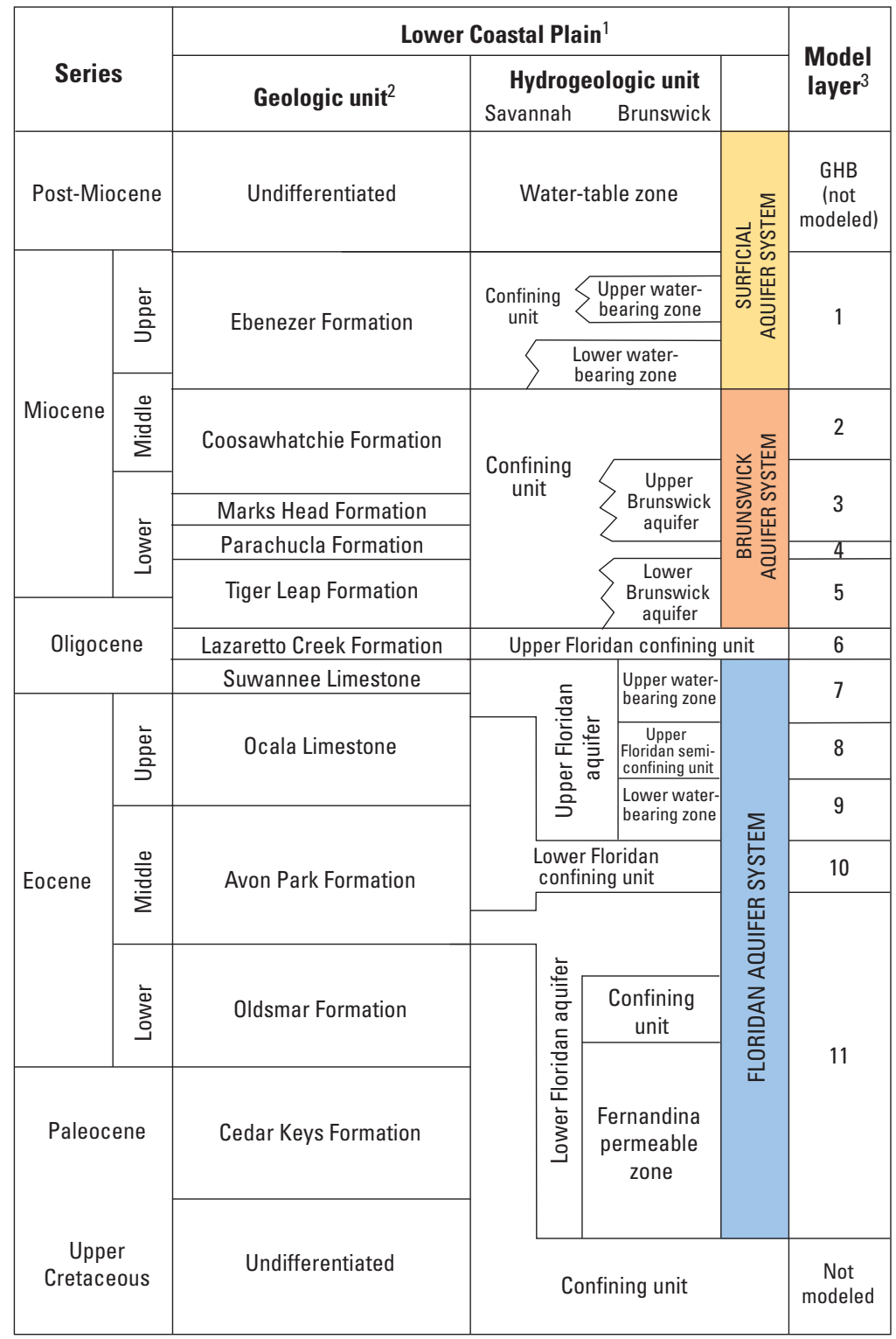

'Modified from Randolph and others, 1991; Clarke and Krause, 2000

${ }^{2}$ Modified from Randolph and others, 1991; Weems and Edwards, 2001

${ }^{3}$ From Payne and others, 2005

Figure 43. Generalized correlation of geologic and hydrogeologic units and model layers. [GHB, general-head boundary] 


\section{Reports and Technical Presentations}

The USGS prepared several reports and technical presentations about coastal Georgia during 2008 and has provided technical briefings and progress reports at monthly meetings of the Glynn County Water Resources Management Advisory Committee (WRMAC). Recent reports and presentations on coastal Georgia include:

- USGS Open-File Report 1297, “Groundwater conditions and studies in the Brunswick-Glynn County area, Georgia, 2007," by Gregory S. Cherry and John S. Clarke (http://pubs.usgs.gov/ of/2008/1297/)

- USGS Scientific Investigations Report 2009-5070, "Ground-water conditions and studies in Georgia, 2006-2007” by Michael F. Peck, Jaime A. Painter, and David C. Leeth (http://pubs.usgs.gov/ sir/2009/5070/)

- Presentation at the 2008 Georgia Association of Water Professionals Spring Conference held in Columbus, GA, titled, "Optimization of groundwater pumping distribution to limit chloride plume expansion in the Upper Floridan aquifer near Brunswick, Georgia," by Gregory S. Cherry and Dorothy F. Payne

- Presentation at the 2008 Greater Atlanta Geomorphology and Hydrology Research Conference held in Atlanta, GA, titled, "Optimization of groundwater pumping distribution to limit chloride plume expansion in the Upper Floridan aquifer near Brunswick, Georgia," by Gregory S. Cherry and Dorothy F. Payne

\section{Selected References}

Barber, N.L., and Stamey, T.C., 2000, Droughts in Georgia: U.S. Geological Survey Open-File Report 00-380, 2 p., accessed September 5, 2008, at http://pubs.usgs.gov/ of/2000/0380/.

Cherry, G.S., 2007, U.S. Geological Survey Georgia Water Science Center and City of Brunswick-Glynn County Cooperative Water Program-Summary of activities, July 2005 through June 2006: U.S. Geological Survey Open-File Report 2006-1368, 64 p., accessed May 19, 2008, at http://pubs.usgs.gov/of/2006/1368/.

Cherry, G.S., 2009, Groundwater modeling and monitoring to manage chloride plume expansion in the Upper Floridan aquifer near Brunswick, Georgia, in Carroll, G.D., ed., Proceedings of the 2009 Georgia Water Resources Conference, held April 27-29, 2009, at the University of Georgia, Athens, Institute of Ecology, The University of Georgia, accessed July 2, 2009, at http://www.gwri.gatech. edu/uploads/proceedings/2009/6.3.3_Cherry.pdf.

Cherry, G.S., and Clarke, J.S., 2008, Ground-water conditions and studies in the Brunswick-Glynn County area, Georgia, 2007: U.S. Geological Survey Open-File Report 20081297, 42 p., available online only at http://pubs.usgs.gov/ of/2008/1297/.

Cherry, G.S., and Payne, D.F., 2007, Optimization of groundwater pumpage distribution to limit chloride plume expansion in the Upper Floridan aquifer near Brunswick, Georgia, in Rasmussen, Todd, Carroll, G.D., and Georgakakos, Aris, eds., Proceedings of the 2007 Georgia Water Resources Conference, held March 27-29, 2007, at the University of Georgia, Athens, Institute of Ecology, The University of Georgia, accessed May 20, 2008, at http://ga.water.usgs.gov/publications/gwrc07/.

Clarke, J.S., 2007, The monitoring and modeling approach to support groundwater management in Georgia, in Rasmussen, Todd, Carroll, G.D., and Georgakakos, Aris, eds., Proceedings of the 2007 Georgia Water Resources Conference, held March 27-29, 2007, at the University of Georgia, Athens, Institute of Ecology, The University of Georgia, accessed May 20, 2008, at http://ga.water.usgs. gov/publications/gwrc07/.

Clarke, J.S., Hacke, C.M., and Peck, M.F., 1990, Geology and groundwater resources of the coastal area of Georgia: Georgia Geologic Survey Bulletin 113, 106 p. 
Clarke, J.S., and Krause, R.E., 2000, Design, revision, and application of groundwater flow models for simulation of selected water-management scenarios in the coastal area of Georgia and adjacent parts of South Carolina and Florida: U.S. Geological Survey Water-Resources Investigations Report 00-4084, 93 p.

Fanning, J.L., and Trent, V.P., 2009, Water use in Georgia by county for 2005; and water-use trends, 1980-2005: U.S. Geological Survey Scientific Investigations Report 2009-5002, 186 p., accessed May 29, 2009, at http://pubs.usgs.gov/sir/2009/5002/.

Georgia Environmental Protection Division, 1997, Secondary maximum contaminant levels for drinking water, Environmental Rule 391-3-5-19, revised October 1997 : Official Code of Georgia Annotated Statutes, Statute 12-5-170 (Georgia Safe Drinking Water Act), variously paged.

Hall, M.E., and Peck, M.F., 2005, Saltwater contamination due to well construction problems-A case study from Vernonberg, Georgia, in Hatcher, K.J. ed., Proceedings of the 2005 Georgia Water Resources Conference, held April 25-27, 2005, at The University of Georgia, Athens, Institute of Ecology, The University of Georgia, accessed November 10, 2005, at http://ga.water.usgs.gov/pubs/ other/gwrc2005/.

Hall, M.E., and Peck, M.F., 2007, Saltwater contamination in the Upper Floridan aquifer in the Savannah/Vernonburg, Georgia, area, 2004-2006, in Rasmussen, Todd, Carroll, G.D., and Georgakakos, Aris, eds., Proceedings of the 2007 Georgia Water Resources Conference, held March 27-29, 2007, at the University of Georgia, Athens, Institute of Ecology, The University of Georgia, accessed May 20, 2008, at http://ga.water.usgs.gov/publications/ gwrc07/.

Harbaugh, A.W., Banta, E.R., Hill, M.C., and McDonald, M.G., 2000, MODFLOW-2000, the U.S. Geological Survey modular groundwater model - User guide to modularization concepts and the groundwater flow process: U.S. Geological Survey Open-File Report 00-92, 121 p.

Leeth, D.C., Peck, M.F., and Painter, J.A., 2007, Groundwater conditions and studies in Georgia, 2004-2005: U.S. Geological Survey Scientific Investigations Report 2007-5017, 299 p., accessed May 19, 2008, at http://pubs. usgs.gov/sir/2007/5017/.

Payne, D.F., 2007, Effects of pumpage reduction in the Savannah, Georgia-Hilton Head Island, South Carolina, area on saltwater intrusion near Hilton Head Island, in Rasmussen, Todd, Carroll, D.G., and Georgakakos, Aris, eds., Proceedings of the 2007 Georgia Water Resources Conference, held March 27-29, 2007, at the University of Georgia, Athens, Institute of Ecology, The University of Georgia, accessed May 20, 2008, at http://ga.water.usgs. gov/publications/gwrc07/.
Payne, D.F., Rumman M.A., and Clarke J.S., 2005, Simulation of groundwater flow in coastal Georgia and adjacent parts of South Carolina and Florida-Predevelopment, 1980, and 2000: U.S. Geological Survey Scientific Investigations Report 2005-5089, 91 p., accessed January 18, 2006, at http://pubs.usgs.gov/sir/2005/5089/.

Peck, M.F., Painter, J.A., and Leeth, D.C., 2009 Groundwater conditions and studies in Georgia, 2006-2007: U.S. Geological Survey Scientific Investigations Report 2009-5070, 86 p.

Randolph, R.B., Pernik, M., and Garza, R., 1991, Water supply potential of the Floridan aquifer system in the coastal area of Georgia-A digital model approach: Georgia Geologic Survey Bulletin 116, $30 \mathrm{p}$.

U.S. Environmental Protection Agency, 2000 revised, Maximum contaminant levels (Part 143, National Secondary Drinking-Water Regulations): U.S. Code of Federal Regulations, Title 40, parts 100-149.

Wait, R.L., 1965, Geology and occurrence of fresh and brackish groundwater in Glynn County, Georgia: U.S. Geological Survey Water-Supply Paper 1613-E, 94 p.

Wait, R.L., and Gregg, D.O., 1974, Hydrology and chloride contamination of the principal artesian aquifer in Glynn County, Georgia Department of Natural Resources Hydrologic Report, 93 p.

Walls, C.B., Cressler, A.M., and Stayton, W.L., 2009, Real-time water-level and specific conductance monitoring of saltwater contamination in the Upper Floridan aquifer, Brunswick, Georgia, in Carroll, D.G., ed., Proceedings of the 2009 Georgia Water Resources Conference, held April 27-29, 2009, at the University of Georgia, Athens, Institute of Ecology, The University of Georgia, accessed July 2, 2009.

Weems, R.E., and Edwards, L.E., 2001, Geology, of Oligocene, Miocene, and younger deposits in the coastal area of Georgia: Georgia Geologic Survey Bulletin 131, 124 p.

Manuscript approved on November 30, 2009

For more information about this publication contact:

Director

USGS Georgia Water Science Center

3039 Amwiler Road, Suite 130

Atlanta, GA 30360

Telephone: 770-903-9100

http://ga.water.usgs.gov 
